\author{
UNIVERSIDADE DE SÃO PAULO \\ FACULDADE DE ODONTOLOGIA DE BAURU
}

MARIMÁRCIO DE MATOS CORSINO PETRÚCIO

Controle Social no Sistema Único de Saúde (SUS): percepção sobre a responsabilidade legal dos Conselhos de Saúde e seus integrantes

BAURU 



\author{
UNIVERSIDADE DE SÃO PAULO \\ FACULDADE DE ODONTOLOGIA DE BAURU
}

MARIMÁRCIO DE MATOS CORSINO PETRÚCIO

Controle Social no Sistema Único de Saúde (SUS): percepção sobre a responsabilidade legal dos Conselhos de Saúde e seus integrantes

Dissertação apresentada a Faculdade de Odontologia de Bauru da Universidade de São Paulo para obtenção do título de Mestre no Programa de Ciências Odontológicas Aplicadas, na área de concentração Saúde Coletiva.

Orientadora: Prof ${ }^{\mathrm{a}}$. Dr ${ }^{\mathrm{a}}$. Nilce Emy Tomita

Versão corrigida

BAURU

2016 


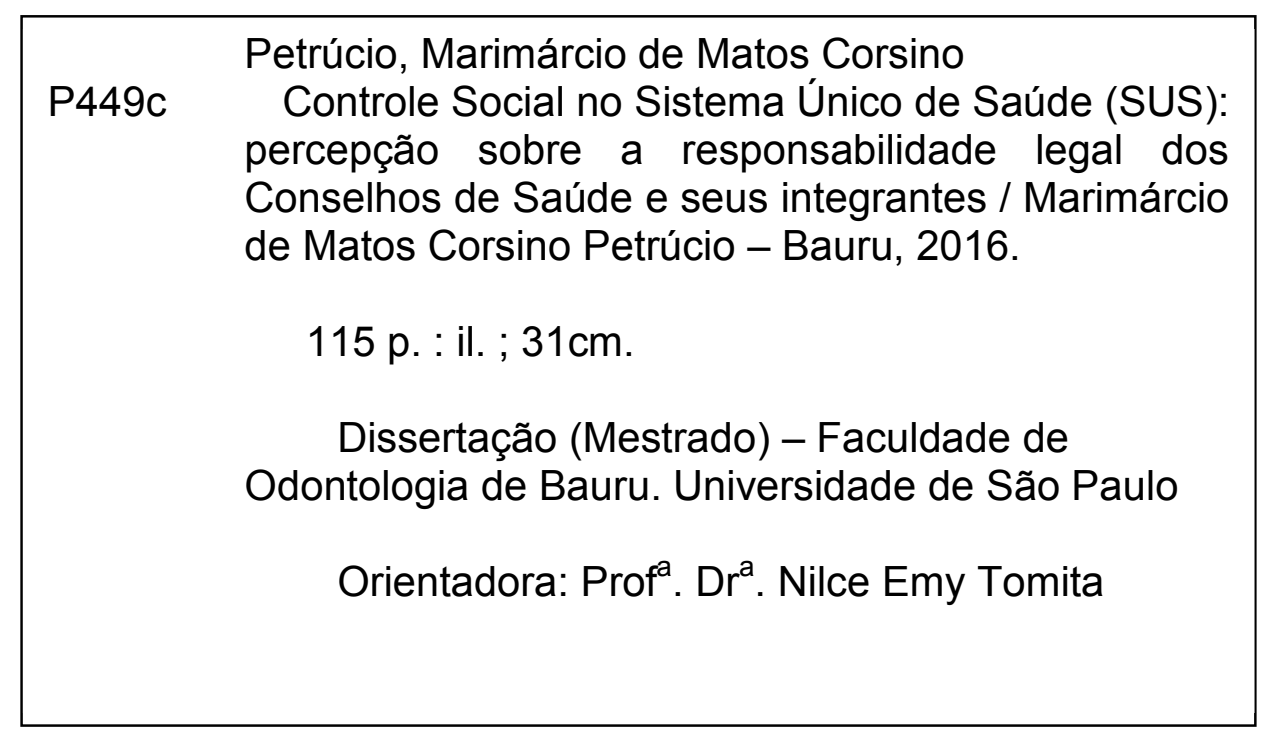

Nota: A versão original desta dissertação encontra-se disponível no Serviço de Biblioteca e Documentação da Faculdade de Odontologia de Bauru - FOB/USP.

Autorizo, exclusivamente para fins acadêmicos e científicos, a reprodução total ou parcial desta dissertação/tese, por processos fotocopiadores e outros meios eletrônicos.

Assinatura:

Comitê de Ética da FOB-USP

Protocolo $\mathrm{n}^{\circ}: 1.235 .563$

Data: 18/09/2015 


\section{DEDICATÓRIA}

Dedico este trabalho ao Deus criador do céu, da terra e a fonte das águas, como testemunho vivo de um milagre moderno, que foi a conclusão desse mestrado.

Dedico, também, à minha família que sempre me apoiou com muito amor, carinho e compreensão. 



\section{AGRADECIMENTOS}

Ao Deus autor da vida, de toda sabedoria e conhecimento, que permitiu a conclusão desse grande desafio.

À minha esposa Janaína e minha filha Maitê, pelo carinho e paciência que tiveram comigo durante toda a jornada do mestrado.

À minha orientadora, Prof ${ }^{2}$. Dr ${ }^{a}$. Nilce Emy Tomita, pela dedicação e apoio nesse trabalho.

Aos meus amigos, Prof. Dr. Paulo Sergio da Silva Santos e o Prof. Dr. Roosevelt da Silva Bastos, os quais sempre terão minha gratidão pelo incentivo e apoio demonstrado nesse desafio intelectual.

À minha cunhada Adriana Teixeira e família, pelo carinho, apoio e incentivo, especialmente por já terem vivido essa experiência desafiadora.

Aos funcionários e professores da área de saúde coletiva e da Diretoria da PósGraduação, pela atenção e a ética profissional apresentada, o que contribuiu para a conclusão desse trabalho.

À Capes pela apoio à esse trabalho científico. 

"A maior necessidade do mundo é a de homens que não se comprem nem se vendam; homens que no íntimo da alma sejam verdadeiros e honestos; [...] homens cuja consciência seja tão fiel ao dever como a bússola o é ao polo; homens que permaneçam firmes pelo que é reto, ainda que caiam os céus". 



\section{RESUMO}

O Conselho de Saúde foi instituído com o objetivo de promover a participação social nas políticas de saúde pública, estabelecendo um mecanismo robusto e permanente de fiscalização e de tomada de decisões, em que o Controle Social foi firmemente integrado à gestão pública. O Controle Social sempre foi um instrumento jurídico, podendo ser exercido por qualquer cidadão, mediante ação popular, ou por instituições, por meio da ação civil pública. Contudo, antes da instituição do Conselho de Saúde, esses instrumentos jurídicos eram apenas uma possibilidade, não constituindo um mecanismo de caráter permanente. Com o estabelecimento dos Conselhos de Saúde como órgão deliberativo e permanente, o Controle Social deixa de ser apenas um direito, tornando-se um órgão público obrigatório na administração da saúde pública. Dentre suas atribuições está a responsabilidade de conhecer, analisar, julgar, cobrar e divulgar as ações do poder executivo em sua esfera de atuação. Esse estudo tem por objetivo analisar a percepção dos membros do Conselho de Saúde quanto às atribuições e prerrogativas no desempenho de suas funções como agente público. Como método de estudo foi realizada uma revisão bibliográfica referente ao tema, em conjunto com estudo transversal, descritivo e qualitativo, baseado na análise do discurso dos sujeitos, realizado por meio de pesquisa com roteiro semiestruturado. Observou-se a falta de percepção do conselheiro quanto a sua atuação como agente público, sujeito a suas prerrogativas e regulamentações. As funções do Conselho de Saúde são complexas, pois incluem a responsabilidade de conhecer, analisar, julgar, cobrar e divulgar os programas de saúde, o que impõe a necessidade de uma qualificação técnica e uma estrutura adequada. Ainda que tal circunstância não exima os membros do Conselho de Saúde da responsabilidade de cumprir a legislação pertinente, assim como a aplicação de critérios técnicos no desempenho de suas funções, no presente estudo observou-se que existe uma percepção por parte dos conselheiros quanto ao despreparo e a falta de qualificação, principalmente em relação à legislação e a estrutura do SUS, o que dificulta o desempenho de suas atividades de Controle Social.

Palavras-chave: Conselhos de Saúde. Participação Social. Responsabilidade Legal. 



\begin{abstract}
The Health Council was instituted with the purpose of promoting the social participation in the public health policies establishing a robust and permanent inspection and decision making mechanism in which the social control has been strongly integrated to the public management. The social control has always been a legal instrument that any citizen can apply through citizen's lawsuits or through institutions using the public civil lawsuits. However, before the institution of the Health Council these legal instruments were just a possibility not constituting a permanent mechanism. With the institution of the Health Councils as deliberative and permanent organs the social control is no longer just a right but becomes a public organ that has to mandatorily be in the management of the public health. Among its attributions is the responsibility to know, analyze, judge, demand and promote the actions from the executive power in its acting sphere. This study has as a goal to analyze the perception of the Health Council members regarding the attributions and prerogatives in the performance of its functions as a public agent. As a study method, a bibliographic review was performed on the theme along with transversal study, descriptive and qualitative, based in the collective subject discourse as observed through recorded interviews with members from the City of Bauru Health Council.
\end{abstract}

Key words: Health Councils. Social Control. Legal Responsibility 



\section{LISTA DE ILUSTRAÇÕES}

Figura 1 - Localização do município de Bauru, SP. 



\section{LISTA DE ABREVIATURA E SIGLAS}

INAMPS Instituto Nacional de Assistência Médica e Previdência Social

SUS Sistema Único de Saúde.

CAP Caixas de Aposentadoria e Pensões

IAP Instituto de Aposentadoria e Pensões

INPS Instituto Nacional de Previdência Nacional

SUDS Sistema Unificado e Descentralizado de Saúde

STF Supremo Tribunal Federal

ACP Ação Civil Pública

LACP Lei de ação civil pública

CDC Código de Defesa do Consumidor

CPC Código de Processo Civil

LC Lei Complementar

CLT Consolidação das Leis do Trabalho

IDH-M Índice de Desenvolvimento Humano Municipal

PIB Produto Interno Bruto

$\mathrm{ECH}$ Expressões Chave

IC Ideia Central

AC Ancoragem

CEP Comitê de Ética em Pesquisa 



\section{SUMÁRIO}

2.1 A EVOLUÇÃO DO CONTROLE SOCIAL NO SISTEMA BRASILEIRO DE SAÚDE.

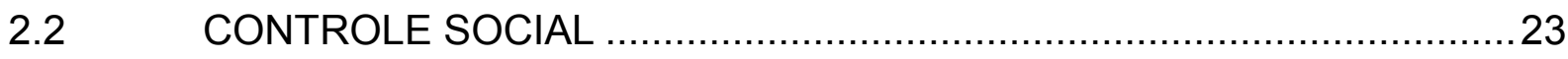

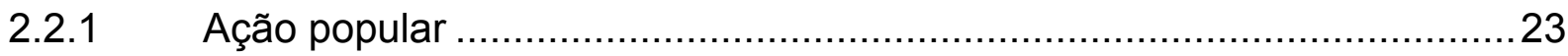

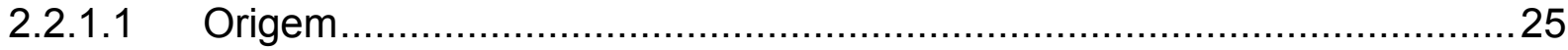

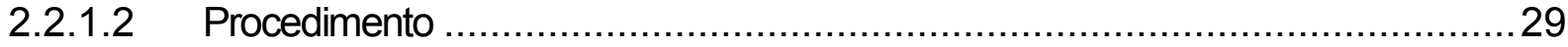

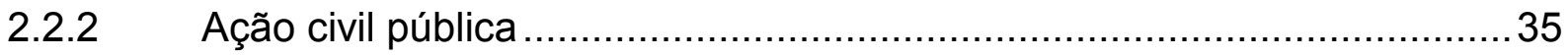

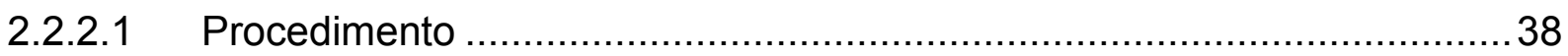

2.2.3 Conselho de Saúde ................................................................. 40

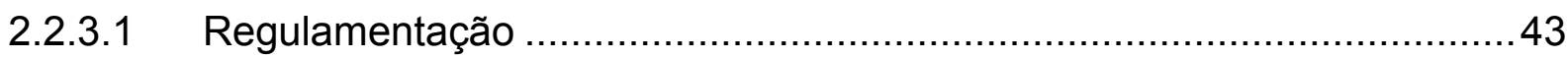

2.2.3.2 Atribuições e competência ..................................................... 45

2.2.3.3 Desempenho das atividades ....................................................... 47

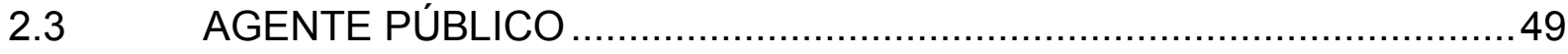

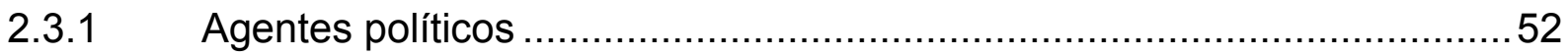

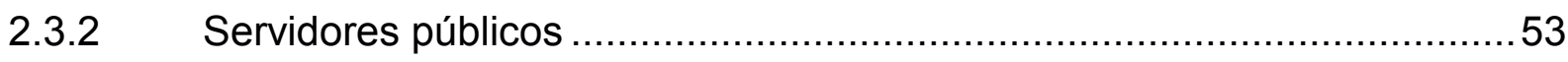

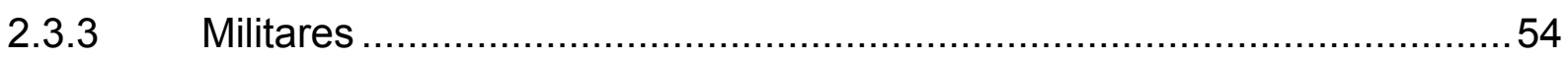

2.3.4 Particulares em colaboração com o Poder Público ................................. 54

2.3.5 O conselheiro como agente público ............................................... 54

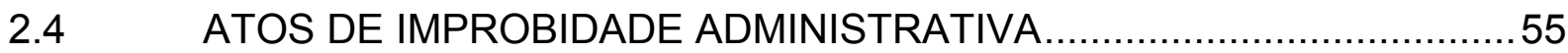

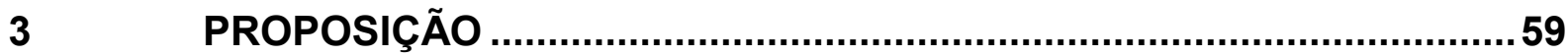

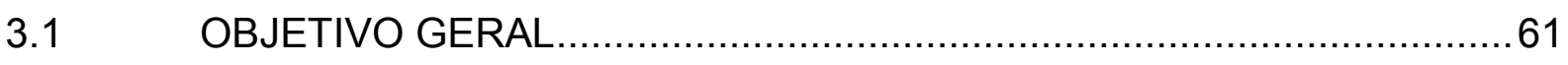

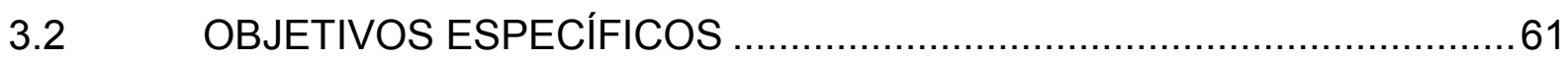

4 MATERIAL E MÉTODO ..................................................................63 63

4.1 CARACTERÍSTICAS DO CENÁRIO DE PESQUISA ...........................65

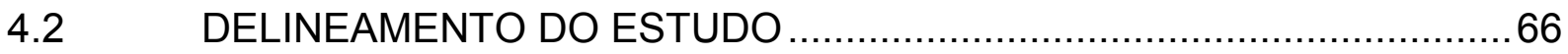

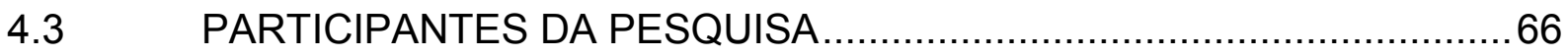





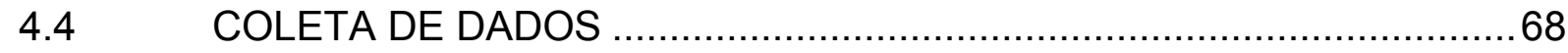

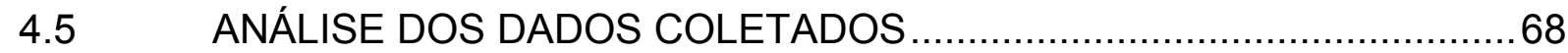

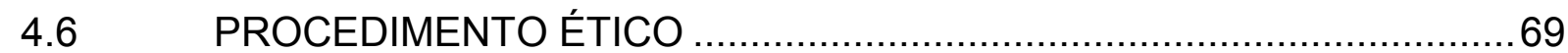

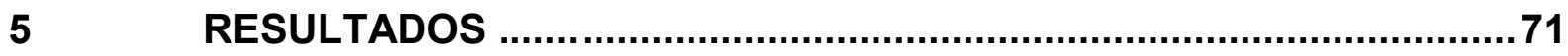

5.1 PREPARO DOS CONSELHEIROS ............................................. 73

5.2 O CONSELHO DE SAÚDE COMO PALANQUE POLÍTICO ...................75

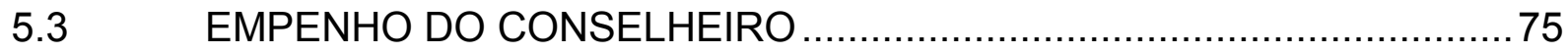

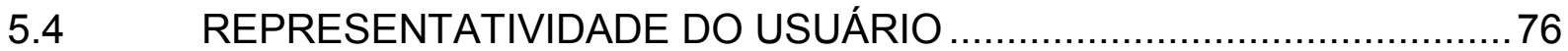

5.5 ENTENDIMENTO SOBRE O FUNCIONAMENTO DO SUS ..................77

5.6 FISCALIZAÇÃO DAS PRESTAÇÕES DE CONTA .............................78

5.7 A NECESSIDADE DE CAPACITAÇÃO DO CONSELHEIRO ................ 79

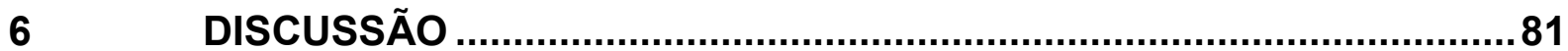

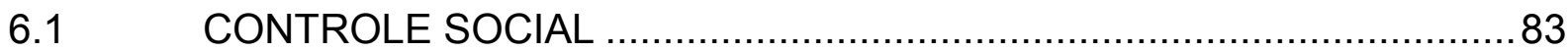

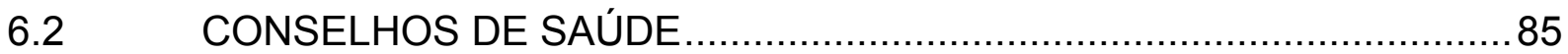

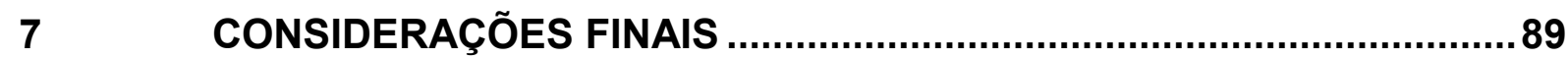

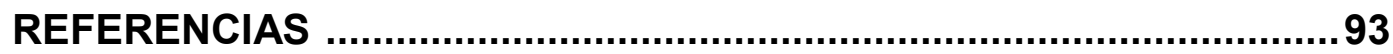

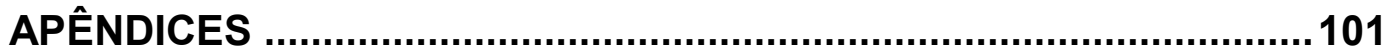

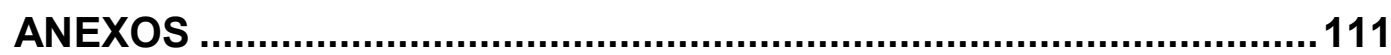



1 INTRODUÇÃO 



\section{INTRODUÇÃO}

A expressão Controle Social tem sua origem na sociologia; o termo pode ser usado para indicar mecanismos que estabelecem e disciplinam a ordem social, determinando modelos sociais e princípios morais. Mannheim (1971, p. 178) a define como o "conjunto de métodos pelos quais a sociedade influencia o comportamento humano, tendo em vista manter determinada ordem", que condiciona as ações do indivíduo aos padrões do grupo ao qual pertence, adotando seus valores e suas normas de comportamento.

O termo Controle Social pode ser ambíguo, indicando o controle do Estado sobre a sociedade ou o controle da sociedade sobre as ações do Estado.

Quando o Estado exerce o Controle Social sobre a sociedade, visa garantir a pacificação e a manutenção da ordem pública em prol do bem comum. Esse controle é realizado por meio da implantação de políticas sociais que interferem no cotidiano dos indivíduos, estabelecendo normas e promovendo meios de satisfação comum (CORREIA, 2009).

No contexto político, o termo Controle Social é a participação da sociedade na fiscalização e controle das políticas públicas. Como instrumento de democracia participativa, permite à sociedade intervir nas decisões do Estado e na elaboração dos planos de governo (CORREIA, 2009).

A expressão Controle Social tem sido usada frequentemente por diversos segmentos da sociedade como sinônimo de participação social nas políticas públicas.

Com a Instituição dos Conselhos de Saúde em 1990 (BRASIL, 1990) o Controle Social avançou significativamente: deixou de ser apenas uma possibilidade jurídica do exercício de cidadania e passou a ser um mecanismo permanente de fiscalização e controle das políticas públicas de saúde.

Segundo Escorel (2008), o Brasil tem alcançado destaque internacional na adoção de um sistema de participação social abrangente e descentralizado, servindo assim como referência. 
A Lei Federal 8.142/90 (BRASIL, 1990, grifo nosso) condicionou o repasse dos recursos federais do setor de saúde aos estados, municípios e ao Distrito Federal, para a implantação dos respectivos Conselhos de Saúde, os quais foram instituídos como órgãos colegiados e permanentes, de caráter deliberativo:

Art. $4^{\circ}$ Para receberem os recursos, de que trata o art. $3^{\circ}$ desta Lei, os Municípios, os Estados e o Distrito Federal deverão contar com:

I - Fundo de Saúde;

II - Conselho de Saúde, com composição paritária de acordo com o Decreto $n^{\circ}$ 99.438, de 7 de agosto de 1990;

III - plano de saúde;

IV - relatórios de gestão que permitam o controle de que trata o $\S 4^{\circ}$ do art. 33 da Lei $n^{\circ} 8.080$, de 19 de setembro de 1990;

$\mathrm{V}$ - contrapartida de recursos para a saúde no respectivo orçamento;

VI - Comissão de elaboração do Plano de Carreira, Cargos e Salários (PCCS), previsto o prazo de dois anos para sua implantação.

Parágrafo único. O não atendimento pelos Municípios, ou pelos Estados, ou pelo Distrito Federal, dos requisitos estabelecidos neste artigo, implicará em que os recursos concernentes sejam administrados, respectivamente, pelos Estados ou pela União. 
2 REVISÃo DE LITERATURA 



\section{REVISÃO DE LITERATURA}

\subsection{A evolução do Controle Social no Sistema Brasileiro de Saúde}

No início do século $X X$, a economia brasileira, inicialmente voltada para a produção de grãos, começou a passar por um processo de industrialização, assimilando a mão de obra dos imigrantes europeus que possuíam experiência e conhecimento técnico (BRASIL, 2013).

Por essa ocasião, os trabalhadores não possuíam quaisquer direitos legais, trabalhando em condições de insalubridade. Nesse cenário, iniciou-se um movimento da classe trabalhista a fim de reivindicar melhores condições de trabalho, o que culminou com duas greves gerais: uma em 1917, e outra em 1919.

Promovidos pelos movimentos operários, esses atos geraram uma pressão social que resultou na criação das Caixas de Aposentadorias e Pensões (CAP) em nível nacional, instituídas por intermédio do Decreto-Lei 4682 de 24 de janeiro de 1923 (BRASIL, 1923).

Conhecida como Lei Eloy Chaves, essa norma legal marcou o surgimento da previdência social no Brasil. As Caixas de Aposentadorias e Pensões ofereciam aos seus funcionários o benefício de aposentadorias, pensões e assistência médica (BRASIL, 2013).

Além dos benefícios previdenciários, o Decreto-Lei 4.682/23 (BRASIL, 1923) também estendia a assistência médica e o auxílio de medicamentos aos beneficiários e seus dependentes, conforme o enunciado do artigo $9^{\circ}$, in verbis:

\footnotetext{
Art. $9^{\circ}$ - Art. $9^{\circ}$ Os empregados ferroviários, a que se refere 0 art. $2^{\circ}$ desta Lei, que tenham contribuído para os fundos da Caixa com os descontos referidos no art. $3^{\circ}$ letra "a" terão direito:

1. a socorros médicos em casos de doença em sua pessoa ou pessoa de sua família, que habite sob o mesmo teto e sob a mesma economia;

2. a medicamentos obtidos por preço especial determinado pelo Conselho de Administração;

3. a aposentadoria;

4. a pensão para seus herdeiros em caso de morte.
}

As Caixas de Aposentadorias e Pensões de algumas categorias profissionais construíram hospitais próprios que foram transformados em Institutos de Aposentadorias e Pensões (IAP) em 1932, quando começaram a contar com a 
participação do Estado no seu custeio. Com uma contribuição tripartite, realizada pelos empregados, pela empresa e pelo Estado, os IAP atuavam como uma base contributiva previdenciária.

Em 1937, com a criação do Estado Novo, o governo Getúlio Vargas estabeleceu um pacto social com visando a incorporação de novas ideias e a legitimação do Estado. Dentre essas inovações, foi estabelecido o Primeiro Conselho Nacional de Saúde, composto por técnicos e membros da sociedade escolhidos pelo governo, com o objetivo de resolver questões internas ao Departamento Nacional de Saúde.

As ações de Saúde Pública ficavam a cargo do Departamento Nacional de Saúde, ligado ao Ministério dos Negócios da Educação e da Saúde Pública, com atividades voltadas prioritariamente para a higiene pública e o controle de endemias, nas áreas portuárias (BRASIL, 2013).

O Governo Federal instituiu as Conferências Nacionais de Saúde por intermédio da Lei 378, de 13 de janeiro de 1937 (BRASIL, 1937), a qual determinava a realização de conferências interministeriais a serem realizadas a cada dois anos, com o objetivo de desenvolver ações em conjunto nas áreas de saúde e de educação:

Art. 90. Ficam instituídas a Conferência Nacional de Educação e a Conferência Nacional de Saúde, destinadas a facilitar ao Governo Federal o conhecimento das atividades concernentes à educação e à saúde, realizadas em todo o País, e a orientá-lo na execução dos serviços locais de educação e de saúde, bem como na concessão do auxílio e da subvenção federais.

Parágrafo único. A Conferência Nacional de Educação e a Conferência Nacional de Saúde serão convocadas pelo Presidente da República, com intervalos máximos de dois anos, nelas tomando parte autoridades administrativas que representem o Ministério da Educação e Saúde.

A I Conferência Nacional de Saúde ocorreu em 1941, no Rio de Janeiro, realizada pelo então Ministério dos Negócios da Educação e Saúde Pública, com o tema "Situação sanitária assistencial dos estados e municípios".

Com o fim do Estado Novo, em 1945, houve mudanças no cenário político brasileiro, especialmente com a promulgação de uma Constituição Federal que restabelecia o Estado de Direito, as garantias individuais e a divisão de poderes.

Em 1950, ocorreu a II Conferência Nacional de Saúde, com o tema "Legislação referente à higiene e segurança do trabalho", na qual foram abordadas 
as condições de higiene e segurança no trabalho, assim como a assistência médica preventiva para trabalhadores e gestantes direcionadas ao combate da malária (BRASIL, 2013).

O Ministério da Saúde foi criado em 1953, o que possibilitou o surgimento de uma política nacional de saúde mais estruturada; porém, ainda com recursos financeiros limitados, o que dificultou o combate às doenças infecciosas e parasitárias que predominavam no Brasil. Nesse período, houve um aumento na estrutura privada de atendimento à saúde, com fins lucrativos.

O Conselho Nacional de Saúde, composto por 17 membros nomeados, ainda estava longe de ser um instrumento de Controle Social (Brasil, 2013).

Em 1963, foi promovida a III Conferência Nacional de Saúde, com o tema "Descentralização na área de saúde", algo inovador: a descentralização na área da saúde, definindo as atribuições nas três esferas de governo.

Com a instauração do regime militar, em 1964, houve mudanças significativas na Política de Saúde Pública, com a adoção de um sistema assistencialista, a fim de aumentar o controle sobre a população e "atenuar as tensões sociais". Nesse cenário, ocorreu um crescimento significativo do sistema de assistência médica vinculada ao sistema previdenciário, além da adoção da prática médica curativa e individual em prejuízo das ações coletivas e o desenvolvimento de um complexo médico-industrial com a conotação de prestação de serviços médicos privados, lucrativos e não lucrativos (Brasil, 2013).

Em 1966, os IAP existentes se fundiram para a criação do Instituto Nacional de Previdência Social (INPS), a fim de regulamentar e executar as políticas de previdência e assistência médica com uma participação maior do Estado. A organização do sistema de saúde, à época, não contemplava os trabalhadores do setor informal da economia.

A IV Conferência Nacional de Saúde, realizada em agosto de 1967, com o tema "Recursos humanos para as atividades de saúde", abordou a questão dos Recursos Humanos, como responsabilidade do Ministério da Saúde.

Na década de 1970, o modelo de assistência médica passou por uma crise devido à inflação gerada pelos próprios profissionais da área da saúde. A assistência médica, com atuação curativa, ocorria por pagamento direto do usuário ao médico ou pelo pagamento pelas empresas por meio de serviços próprios ou conveniados. 
Em agosto de 1975, foi realizada em Brasília a V Conferência Nacional de Saúde, intitulada "Constituição do Sistema Nacional de Saúde e a sua institucionalização", que discutiu temas relacionados ao programa nacional de saúde materno-infantil; sistema nacional de vigilância epidemiológica; programa de controle das grandes endemias e extensão das ações de saúde às populações rurais, visando a uma estruturação de uma politica nacional (BRASIL, 2013).

A VI Conferência Nacional de Saúde, realizada em agosto de 1977, com o tema "Controle das grandes endemias e interiorização dos serviços de saúde", colocou em pauta a questão das endemias e da aplicação das novas Leis sanitárias, além de discutir a política nacional do setor de saúde pública. Nesse mesmo ano, foi criado o Instituto Nacional de Assistência Médica e Previdência Social (INAMPS), proporcionando maior atendimento da população (todos os trabalhadores urbanos formalmente inseridos no mercado de trabalho e parte dos trabalhadores rurais), 0 que consequentemente aumentou os custos do programa (BRASIL, 2013).

Nesse período, quem precisasse de assistência médica deveria pagar por atendimento do serviço privado, ser atendido em instituições filantrópicas ou estar inserido no mercado de trabalho de maneira formal. Essa última categoria de atendimento pode ser denominada "cidadania regulada", uma vez que os direitos do cidadão estavam ligados diretamente à formalização do trabalho (BRASIL, 2013).

As campanhas de enfoque preventivo (vacinação, saneamento, controle de endemias, etc.) eram de acesso universal, funcionando em paralelo com o modelo curativo. Em consequência, o modelo adotado de atenção à saúde era insuficiente para atender a população.

Essa insuficiência, somada à tecnificação crescente da medicina e os interesses privados, foi a responsável por um crescimento desordenado dos gastos do setor saúde, sem resultar em melhoria da assistência médica ou em melhores condições de saúde para a população.

A VII Conferência Nacional de Saúde, realizada em agosto de 1980, com o tema "Extensão das ações de saúde através dos serviços básicos", apresentou um modelo de gestão pública com uma proposta de unificação e descentralização da saúde.

Devido à resistência apresentada por alguns setores, inclusive pelo Instituto Nacional de Assistência Médica da Previdência Social (INAMPS), a proposta de unificação e descentralização foi rejeitada (BRASIL, 2013). 
As alterações sofridas pelo sistema de saúde brasileiro estiveram, de alguma forma, relacionadas com o momento político e histórico do país. Uma mudança significativa ocorreu em virtude do movimento chamado "Reforma Sanitária Brasileira", formado por médicos, estudantes e outros profissionais de diversas áreas em uma iniciativa sem qualquer vínculo partidário, promovendo discussões políticas com a finalidade de apresentar uma nova proposta para o setor saúde.

Essa ação social pretendia alterações profundas no setor saúde e não apenas algumas adaptações aos padrões já existentes à época. Defendia que a saúde fosse um direito do cidadão e um dever do Estado, com abrangência universal e acesso a todos os bens e serviços que a promovam e a recuperem (BRASIL, 2013).

A retomada da democracia deixou evidente a necessidade de um novo modelo para o setor saúde. As principais propostas de mudança ocorreram na VIII Conferência Nacional de Saúde, em 1986, na qual houve a indicação de uma reformulação do sistema de saúde com a adoção de um modelo que incluísse a universalização do acesso à saúde, um sistema unificado com as decisões tomadas de forma descentralizada, em cada esfera do governo, novos mecanismos de gestão da saúde pública e o Controle Social (BRASIL, 2013).

O Governo Federal, em 1987, instituiu o Sistema Unificado e Descentralizado de Saúde (SUDS), na expectativa de colocar em prática algumas das propostas de reforma sanitária apresentadas na VIII Conferência Nacional de Saúde. Entretanto, com a instauração da Assembleia Nacional Constituinte, o sistema de saúde foi debatido de forma mais ampla, o que possibilitou a proposição do atual Sistema Único de Saúde.

Somente com a Constituição Federal de 1988, a saúde foi reconhecida como um direito fundamental, o que possibilitou a criação do Sistema Único de Saúde (SUS), uma instituição que adotou, dentre outros, o princípio da universalidade, estendendo a assistência à saúde a toda população. Faz parte de suas diretrizes a administração única e descentralizada, assim como participação objetiva da comunidade (BRASIL, 1988): 
Art. 198. As ações e serviços públicos de saúde integram uma rede regionalizada e hierarquizada e constituem um sistema único, organizado de acordo com as seguintes diretrizes:

I - descentralização, com direção única em cada esfera de governo;

II - atendimento integral, com prioridade para as atividades preventivas, sem prejuízo dos serviços assistenciais;

III - participação da comunidade.

Ao considerar as ações e os serviços de saúde como sendo de relevância pública, a Constituição Federal (BRASIL, 1988, grifos nossos) dispôs, no artigo 197, a obrigação do Estado em estabelecer mecanismos capazes de avaliar, fiscalizar e controlar o sistema de saúde.

Art. 197. São de relevância pública as ações e serviços de saúde, cabendo ao Poder Público dispor, nos termos da Lei, sobre sua regulamentação, fiscalização e controle, devendo sua execução ser feita diretamente ou através de terceiros e, também, por pessoa física ou jurídica de direito privado.

Ao adotar as prerrogativas de estado democrático de direito, a Constituição instituiu instrumentos que permitiram o aprimoramento do Controle Social, conforme descreve Longhi e Canton (2011, p.17, grifos nossos):

O Estado e os setores da sociedade civil comprometidos com o projeto participativo democratizante substituem o confronto aberto da década anterior, período de ditadura militar, por uma aposta na possibilidade de uma atuação conjunta com o Estado através de espaços institucionalizados de participação popular. A chamada "inserção institucional" dos movimentos sociais e evidência dessa inflexão. O confronto e o antagonismo que tinham marcado profundamente a relação entre o Estado e a sociedade civil nas décadas anteriores cederam lugar a uma aposta na possibilidade da sua ação conjunta para o aprofundamento democrático.

A Constituição de 1988 concebe a noção de Estado democrático de direito. Este passa a garantir, além da proteção das liberdades individuais, a participação destes na formulação e monitoramento de suas políticas públicas.

Com a determinação constitucional, coube ao Estado regulamentar a criação dos mecanismos de controle e fiscalização por intermédio de norma infraconstitucional, Lei 8.142/1990 (BRASIL, 1990, grifos nossos):

Art. $1^{\circ} \mathrm{O}$ Sistema Único de Saúde (SUS), de que trata a Lei $\mathrm{n}^{\circ} 8.080$, de 19 de setembro de 1990, contará, em cada esfera de governo, sem prejuízo das funções do Poder Legislativo, com as seguintes instâncias colegiadas:

I - a Conferência de Saúde; e

II - o Conselho de Saúde.

$\S 1^{\circ}$ A Conferência de Saúde reunir-se-á a cada quatro anos com a representação dos vários segmentos sociais, para avaliar a situação de saúde e propor as diretrizes para a formulação da política de saúde nos 
níveis correspondentes, convocada pelo Poder Executivo ou, extraordinariamente, por esta ou pelo Conselho de Saúde.

$\S 2^{\circ} \mathrm{O}$ Conselho de Saúde, em caráter permanente e deliberativo, órgão colegiado composto por representantes do governo, prestadores de serviço, profissionais de saúde e usuários, atua na formulação de estratégias e no controle da execução da política de saúde na instância correspondente, inclusive nos aspectos econômicos e financeiros, cujas decisões serão homologadas pelo chefe do poder legalmente constituído em cada esfera do governo.

Gerschman (2004, p. 1.674) sinaliza a instituição do Controle Social como um marco da democracia na sociedade:

No campo da saúde e na conjuntura da transição à democracia, essa noção indicava uma nova modalidade de relacionamento da sociedade com o Estado. O Controle Social foi concebido como a fiscalização direta da sociedade civil nos processos de gestão da coisa pública e consistiria na apropriação, pela sociedade organizada, dos meios e instrumentos de planejamento, fiscalização e análise das ações e dos serviços de saúde.

\subsection{Controle Social}

\subsubsection{Ação popular}

A ação popular é um instrumento processual constitucional que permite ao cidadão comum exercer o Controle Social, questionando, junto ao poder judiciário, as decisões da administração que podem trazer prejuízos ao bem público. No exercício democrático, é uma importante ferramenta de Controle Social, que visa à intervenção direta nos atos lesivos ao bem comum. Foi inserida no ordenamento jurídico pátrio com o fim de contestar os atos prejudiciais praticados pela administração pública direta ou indireta. Busca a anulação ou a reparação do dano decorrente de decisões ilegais ou que contrariam a moralidade administrativa, que lesam o patrimônio histórico, cultural, do meio ambiente, assim como o patrimônio público ou de entidades que tenham a participação do Estado.

Possui natureza regressiva quando busca a anulação dos atos lesivos e a cessação de seus efeitos. Além disso, pode ser proposta de forma preventiva, impedindo a ocorrência de atos que venham trazer prejuízo ao bem tutelado. Essa ferramenta jurídica também pode ser usada para corrigir a omissão de atos da administração pública, os quais deveriam ser praticados. 
É válido ressaltar que a ação popular é um remédio jurídico que não pode ser usado na busca de uma satisfação puramente individual, ou seja, o autor na lide processual não busca a satisfação de um interesse particular, mas da coletividade.

A doutrina defendida por Medina (2006) ressalta que a ação popular não é apenas uma forma de garantia dos direitos fundamentais, mas também, antes de tudo, importante instrumento de participação política do cidadão para a defesa do patrimônio público, da moralidade administrativa, do meio ambiente e do patrimônio histórico-cultural. São a estes bens que se consagra a actio referenciada.

Em um entendimento doutrinário mais amplo, Almeida (2003) classifica a ação popular como possuindo dupla natureza jurídica. Primeiramente é considerada como um direito constitucional político de participação direta na fiscalização da administração pública; em segundo lugar como uma garantia processual constitucional de agir no exercício direto desse direito político de participação. Tanto como direito político do cidadão ou como garantia processual de agir, a ação popular é portadora da dignidade constitucional.

Reis (2014) descreve, de forma objetiva, a ação popular como umbilicalmente ligada à noção de democracia do Estado brasileiro, um instituto de direito constitucional processual voltado à participação política e democrática do cidadão no seio da administração pública.

A ação popular representa uma forma de democracia direta elencada no texto constitucional com a mesma importância do direito ao voto, à iniciativa popular (de projeto de Lei), ao referendo, ao plebiscito e à organização e participação nos partidos políticos. É ela, em suma, uma ação judicial de cunho participativo democrático popular. A sua natureza axiológica permite a manifestação direta do cidadão na participação democrática na fiscalização da Administração Pública, conforme descrita por Reis (2014, p. 52):

É de clareza solar, portanto, que o fundamento constitucional da ação popular resta encravado no princípio democrático e no da soberania popular. Como todo poder emana do povo, ente este cuja atuação se dá direta e indiretamente, ao cidadão é declinada a possibilidade de intervir no rumo da Administração Pública para fins corretivo-reparatórios, desde que verificada a hipótese de violação aos seus principais vetores, legalidade, moralidade, etc. 
Esse entendimento é confirmado na doutrina de Meirelles (1995, p. 87):

Ação popular é o meio constitucional posto à disposição de qualquer cidadão para obter a invalidação de atos ou contratos administrativos - ou a este equiparado - ilegais e lesivos do patrimônio federal, estadual ou municipal, ou de suas autarquias, entidades paraestatais e pessoas jurídicas subvencionadas com dinheiros públicos.

A peculiaridade da ação popular desde sua implantação no ordenamento jurídico é a necessidade de preservação do interesse público, mesmo que em paralelo com o interesse particular, conforme anota Silva (2007, p. 23-24):

Sempre que houvesse um interesse público, e fosse atribuída a ação cuivis e populo, aí se configuraria a ação popular, estivesse o direito público mesclado ou confundido com o interesse privado, ou fosse simplesmente público.

\subsubsection{Origem}

As primeiras evidências do surgimento da ação popular podem ser notadas no Direito Romano, no qual surgiram as ações conhecidas como actiones populares. As primeiras ações foram propostas com o objetivo de atender aos interesses da coletividade.

Bielsa (1955) enfatiza que, na Roma Antiga, já existiam ferramentas jurídicas que poderiam ser usadas por qualquer cidadão romano em defesa da moralidade administrativa, da segurança pública e dos bens comuns. As actiones populares, no Direito Romano, outorgavam poderes ao cidadão a fim de resguardar o interesse estatal e social.

Nesse sentido, Silva (2007, p. 29) comenta, em sua doutrina:

No direito intermédio a ação popular teve várias vicissitudes. Certo, até quando e até onde o direito romano manteve sua poderosa influência e foi aplicado como direito comum, essa ação foi observada e adotada compativelmente com os regulamentos políticos dos Estados e das cidades, em que o direito mesmo se impôs. Certo é também que o direito bárbaro não conheceu esse instituto de modo específico, a não ser que se queira admitir, o que não cremos exato, que a acusação pública fosse uma forma específica de ação popular. Certo é, enfim, que o modo amplo e seguro, onde esta foi reconhecida, sancionada, aplicada e interpretada entre os romanos, não encontra nenhuma correspondência no direito feudal, nem no estatutário. Acrescenta que "onde [...] o regime político assume caráter de absolutismo e de despotismo, a ação popular primitiva, aquela que convoca qualquer um a participar na tutela da coisa pública, não podia surgir". 
Corrêa Telles (1918) classifica como ações populares aquelas que poderiam ser postuladas por qualquer pessoa do povo em defesa das coisas públicas. Mesmo que intentando algum possível benefício imediato ao autor, não afastava sua legitimidade, desde que fosse fundamentada em um interesse público relevante. Cita como exemplos de ação popular, no regime das Ordenações, o fato de que qualquer cidadão poderia promover contra quem houvesse usurpado terreno baldio ou iniciado construção prejudicial a um lugar público como a rua, o rio, etc.

Desde o inicio do ordenamento jurídico pátrio que regulamentou o instituto da ação popular, foi estabelecido como condição à sua propositura a necessidade de satisfação do interesse público, conforme comenta Silva (1998, p. 349): "sempre que houvesse um interesse público, e fosse atribuída a ação cuivis e populo, aí se configuraria a ação popular, estivesse o direito público mesclado ou confundido com o interesse privado, ou fosse simplesmente público".

No regime das ordenanças já existia a possibilidade de qualquer pessoa do povo promover ação contra quem houvesse tomado posse de imóvel público ou iniciado construção prejudicial, o que é considerado por Corrêa Telles (1918) como prelúdio da ação popular.

De forma semelhante, a Primeira Constituição Brasileira, de 1824 (BRASIL, 1824), já previa os casos em que o cidadão comum poderia promover essa modalidade de ação ao estabelecer:

Art. 157: Por suborno, peita, peculato e concussão haverá contra eles a ação popular, que poderá ser intentada dentro de ano e dia pelo próprio queixoso ou por qualquer do povo, guardada a ordem do processo estabelecido na Lei.

Para Alvim (1983), a Constituição Imperial, ao instituir esse instrumento processual, destaca-se como inovadora por sua originalidade, especialmente no fato de ser contemporânea aos textos romanos, à época vigente no Brasil, em decorrência das Ordenações.

A ação popular foi suprimida na Constituição Republicana de 1891, porém albergada pelo legislador constitucional na Carta Magna de 1934 (BRASIL, 1934):

Art. 113 - A Constituição assegura a brasileiros e a estrangeiros residentes no País a inviolabilidade dos direitos concernentes à liberdade, à subsistência, à segurança individual e à propriedade, nos termos seguintes: $[\ldots]$ 
Qualquer cidadão será parte legítima para pleitear a declaração de nulidade ou anulação dos atos lesivos do patrimônio da União, dos Estados ou dos Municípios.

Os avanços desse instrumento democrático restabelecidos pelo legislador constitucional de 1934 foram breves, pois foram suprimidas do ordenamento jurídico com o surgimento do Estado Novo. Mancuso (2003, p. 62) cita essa curta duração do texto constitucional, que sucumbiu com o estabelecimento do novo regime político em 1937, causando retrocessos no ordenamento jurídico:

Os pálidos encômios com que a ação popular veio recepcionada pela inteligência jurídica nacional não foram, porém, suficientes para que ela sobrevivesse ao advento do Estado Novo e assim foi que, decorridos cerca de três anos da sua fugaz existência, não resistiu ela ao tacão da ditadura que se veio a instalar, acabando suprimida na Carta outorgada em 1937.

Nos demais ordenamentos constitucionais de 1967 e 1969, a ação popular foi mantida como ferramenta democrática de fiscalização dos atos lesivos do Estado. Com a promulgação da Carta Magna de 1988 ampliou-se a abrangência do referido instituto com previsão expressa no artigo $5^{\circ}$, LXXIII:

Art. $5^{\circ}$. [...] LXXIII - Qualquer cidadão é parte legítima para propor ação popular que vise a anular ato lesivo ao patrimônio público ou de entidade de que o Estado participe, à moralidade administrativa, ao meio ambiente e ao patrimônio histórico e cultural, ficando o autor, salvo comprovada má-fé, isento de custas judiciais e do ônus da sucumbência (BRASIL, 1988).

Houve um cuidado do legislador em garantir a ação popular como instrumento democrático na Carta Magna, ainda que já existisse a regulamentação infraconstitucional pela Lei № 4.717/65 (BRASIL, 1965):

Art. $1^{\circ}-$ Qualquer cidadão será parte legítima para pleitear a anulação ou a declaração de nulidade de atos lesivos ao patrimônio da União, do Distrito Federal, dos Estados e dos Municípios, de entidades autárquicas, de sociedades de economia mista (Constituição art. 141, § 38), de sociedades mútuas de seguro nas quais a União representa os segurados ausentes, de empresas públicas, de serviços sociais autônomos, de instituições ou fundações para cuja criação ou custeio o tesouro público haja concorrido ou concorra com mais de cinquenta por cento do patrimônio ou da receita ânua de empresas incorporadas ao patrimônio da União, do Distrito Federal, dos Estados e dos Municípios e de quaisquer pessoas jurídicas ou entidades subvencionadas pelos cofres públicos. 
Com as mudanças feitas pela Constituição Federal de 1988, a ação popular passou a alcançar não só a administração pública direta, mas abrangeu também a administração pública indireta, como enfatizado por Silva (1998, p. 462).

Finalmente, do plenário saiu a ação popular na forma prevista no $\S 38$ do Art. 141 da Constituição de 1946. Incluíram-se, no âmbito de controle da ação popular, também os atos lesivos ao patrimônio das autarquias e das sociedades de economia mista, o que não ocorria no regime da Constituição de 1934. Atendeu-se, assim, ao processo evolutivo da Administração Pública, que, naquele tempo, se descentralizava por meio de entidades autárquicas, bem como ao fenômeno do intervencionismo estatal através de empresas públicas e das sociedades de economia mista.

Não se exclui a possibilidade do uso de outros instrumentos processuais capazes de defender os princípios constitucionais que regem a Administração Pública. Segundo Silva (2007), a peculiaridade da ação popular consiste na exclusividade da titularidade em favor do cidadão, concretizando um direito positivo de natureza essencialmente política, assim como a manifestação direta da soberania popular consubstanciada no art. $1^{\circ}$, parágrafo único, da Constituição.

Nesse mesmo sentido, Moraes (2009, p. 165) enfatiza:

A ação popular, juntamente com o direito de sufrágio, direito de voto em eleições, plebiscitos e referendos, e ainda a iniciativa popular da Lei e o direito de organização e participação de partidos políticos, constituem formas de exercícios da soberania popular (CF, arts. $1^{\text {a }}$ e 14), pela qual, na presente hipótese, permite-se ao povo, diretamente, exercer a função fiscalizatória do Poder Público, com base no princípio da legalidade dos atos administrativos e no conceito de que a res pública (República) é patrimônio do povo.

Para Medina (2006), a instituição da ação popular tem a prerrogativa de não apenas garantir os direitos fundamentais, mas também, ser importante instrumento de participação política do cidadão para a defesa do patrimônio público, da moralidade administrativa, do meio ambiente e do patrimônio histórico-cultural, como bens a que se destina o instrumento constitucional.

Está em concordância com a doutrina predominante, os ensinamentos de Dinamarco (2001), para quem a ação popular é um instituto processual civil colocado à disposição de qualquer cidadão como garantia político-constitucional e com o objetivo de defender os interesses da coletividade, mediante a provocação do poder judiciário, impedindo atos lesivos do patrimônio público, da moralidade administrativa, do meio ambiente e do patrimônio histórico e cultural. 


\subsubsection{Procedimento}

O bem jurídico tutelado por meio da ação popular é o ato ilegal e lesivo ao patrimônio público, como definido pelo próprio teor do artigo $5^{\circ}$, LXXIII, da Constituição Federal (BRASIL, 1988), o qual busca anular ou impedir decisões administrativas que possam violar os princípios que regem a administração pública, especialmente os elencados no artigo 37 do texto legal. Dessa forma, o instrumento processual constitucional serve para reparar ou prevenir a lesão ao patrimônio público, à moralidade administrativa, ao meio ambiente e ao patrimônio histórico e cultural.

Esses atos lesivos foram citados por Meirelles (1995, p. 95): "Os direitos pleiteáveis na ação popular são de caráter cívico-administrativo, tendentes a repor a administração nos limites da legalidade e a restaurar o patrimônio público do desfalque sofrido".

A peculiaridade do objeto da ação popular são as consequências do ato que se busca anular. Diante disso, mesmo que não haja intenção objetiva do gestor em lesionar o bem tutelado, se o resultado de suas ações resultar em prejuízo, de forma direta ou indireta, então estará sujeito à norma.

Importante ressaltar que os atos administrativos ao qual se busca intervir com a ação popular não se restringem ao prejuízo patrimonial, alcançando decisões comprovadamente ilegais ou que afronta o princípio da moralidade, conforme Siqueira JR. (2012, p. 549-550):

A lesão ao patrimônio público não é apenas financeira ou econômica, admitindo-se a lesão não econômica, moral, cívica ou cultural, na medida em que o texto constitucional afirma que a ação popular visa anular também ato lesivo à moralidade administrativa, ao meio ambiente e ao patrimônio histórico e cultural. "Enquanto a sua finalidade, no passado, era simplesmente patrimonial, visando à anulação de atos lesivos ao patrimônio de entidades públicas, o constituinte de 1988 admitiu sua utilização também em relação a valores não econômicos, como a moralidade administrativa, o meio ambiente e o patrimônio histórico e cultural, mantendo-se sempre a exigência de ilegalidade. Assim, exige-se o binômio ilegalidade-lesividade para a propositura da ação, dando-se tão somente sentido mais amplo à lesividade, que pode não importar prejuízo patrimonial, mas a lesão a outros valores, protegidos pela Constituição". Nesse sentido, o Supremo Tribunal Federal entendeu que "para o cabimento da ação popular, basta a ilegalidade do ato administrativo a invalidar, por contrariar normas específicas que regem sua prática ou por se desviar dos princípios que norteiam a Administração Pública, dispensável a demonstração de prejuízo material aos cofres públicos, não é ofensivo ao inc. LXXIII do art. $5^{\circ}$ da Constituição Federal, norma esta que abarca não só o patrimônio moral, o cultural e o histórico. 
Uma inovação trazida pela Constituição Federal (BRASIL, 1988), artigo 37, foi a ampliação da tutela da Ação Popular, alcançando a moralidade administrativa, além dos valores patrimoniais. Da mesma forma, atos administrativos perfeitamente fundamentados na legalidade, mas que resultem em prejuízo ao patrimônio público, estarão sujeitos ao instrumento processual.

O princípio da moralidade na administração é a simples gestão nos termos das normas sem lesar o patrimônio público, especialmente de boa-fé, segundo Waline (1963), que atesta sobre precedentes produzidos pelo Conselho de Estado francês:

A jurisprudência anulava atos que não tinham nada de ilegalidade, mas que eram contrários à moralidade administrativa, isto é, a certas regras de boa administração, da administração orientada no sentido só do interesse público.

Nesse mesmo sentido, de acordo com Bandeira de Mello (2001, p, 72):

[...]a administração e seus agentes têm de atuar na conformidade de princípios éticos. Violá-los implicará violação ao próprio Direito, configurando ilicitude que as sujeitam a conduta viciada à invalidação, porquanto tal princípio assumiu foros de pauta jurídica, na conformidade do art. 37 da Constituição.

O tema não encontra um consenso amplo na doutrina processualista, pois, em sentido contrário, Barbosa Moreira (1991) defende a necessidade de o autor popular comprovar que a ação guerreada tenha violado algum tipo de norma, conjugando a imoralidade com a ilegalidade sob o risco de incidir subjetivismo indesejado.

Em apoio a esse entendimento, outros doutrinadores defendem que, caso o poder judiciário exerça a jurisdição nos atos administrativos sob suspeita lastreados apenas na imoralidade, poderia sobrepujar as decisões discricionárias típicas da administração pública. Esse pensamento é também defendido por Medina (2006, p. 125-126):

As considerações precedentes em torno da moralidade administrativa, como objeto de tutela pela ação popular, já deixaram entrever a feição especial da causa petendi, nessa ação. Para a sua configuração plena, é mister que o ato impugnado, além de causar dano a um dos bens e valores que a ação visa a proteger, ofenda a letra ou o espírito de disposição legal de qualquer natureza. O binômio ilegalidade-lesividade há de estar presente, para que o ato possa ser anulado por via da ação popular. Sem que se alegue vício de 
legalidade, suscetível de ensejar a anulação do ato, não se configurará a primeira das condições da ação - a possibilidade jurídica do pedido - e o autor dela será julgado carecedor. Sem a efetiva ocorrência da ilegalidade invocada e a prova da lesão que dela decorra, o pedido será julgado improcedente, ressalvada, nesse último caso, a possibilidade de aplicação do disposto no art. 18 da Lei n. ${ }^{\circ} 4.717 / 65$.

Uma qualidade essencial para figurar como parte legítima no polo ativo da ação popular é que o indivíduo seja cidadão em pleno gozo dos seus direitos políticos. Na descrição do artigo $5^{\circ}$ da Carta Magna (BRASIL, 1988), o texto é específico:

LXXIII - qualquer cidadão é parte legítima para propor ação popular que vise a anular ato lesivo ao patrimônio público ou de entidade de que o Estado participe, à moralidade administrativa, ao meio ambiente e ao patrimônio histórico e cultural, ficando o autor, salvo comprovada má-fé, isento de custas judiciais e do ônus da sucumbência;

A regulamentação dada à Ação Popular pelo artigo $1^{\circ}, \S 3^{\circ}$, da Lei 4.717/1965 (BRASIL, 1965), define a forma pela qual deve ser demonstrada a qualidade de cidadão necessária à propositura da lide em tela, que é a apresentação do título de eleitor:

Art. $1^{\circ}$ Qualquer cidadão será parte legítima para pleitear a anulação ou a declaração de nulidade de atos lesivos ao patrimônio da União, do Distrito Federal, dos Estados e dos Municípios, de entidades autárquicas, de sociedades de economia mista (Constituição art. 141, § 38), de sociedades mútuas de seguro nas quais a União representa os segurados ausentes, de empresas públicas, de serviços sociais autônomos, de instituições ou fundações para cuja criação ou custeio o tesouro público haja concorrido ou concorra com mais de cinquenta por cento do patrimônio ou da receita ânua de empresas incorporadas ao patrimônio da União, do Distrito Federal, dos Estados e dos Municípios e de quaisquer pessoas jurídicas ou entidades subvencionadas pelos cofres públicos.

$\S 3^{\circ} \mathrm{A}$ prova da cidadania, para ingresso em juízo, será feita com o título eleitoral, ou com documento que a ele corresponda.

Por determinação legal ficam impedidos de promover esse instrumento processual os cidadãos que não exercem plenamente a cidadania pátria. A Constituição Federal (BRASIL, 1988) nos artigos, 12, §4 15 e 37, elenca as circunstâncias em que o indivíduo perde a cidadania brasileira:

Art. $12[\ldots]$

$\S 4^{\circ}$. Será declarada a perda da nacionalidade do brasileiro que:

I - tiver cancelada sua naturalização, por sentença judicial, em virtude de atividade nociva ao interesse nacional; 
II - adquirir outra nacionalidade, salvo nos casos:

Art. 15. É vedada a cassação de direitos políticos, cuja perda ou suspensão só se dará nos casos de:

I - cancelamento da naturalização por sentença transitada em julgado;

II - incapacidade civil absoluta;

III - condenação criminal transitada em julgado, enquanto durarem seus efeitos;

IV - recusa de cumprir obrigação a todos imposta ou prestação alternativa, nos termos do artigo $5^{\circ}$, VIII;

$\mathrm{V}$ - improbidade administrativa, nos termos do artigo $37, \S 4^{\circ}$.

Art. $37[\ldots]$

$\S 4^{\circ}$. Os atos de improbidade administrativa importarão a suspensão dos direitos políticos, a perda da função pública, a indisponibilidade dos bens e o ressarcimento ao erário, na forma e gradação previstas em Lei, sem prejuízo da ação penal cabível.

Conforme Siqueira JR. (2012, p. 545), a democracia só pode ser exercida pelo cidadão em plena vida política, pois, assim como o voto, a ação popular fiscaliza a gestão da coisa pública:

O exercício da cidadania configura-se como um dos desdobramentos do Estado Democrático e Social de Direito, constituindo princípio fundamental da República Federativa do Brasil. A cidadania credencia o cidadão a participar da vida efetiva do Estado como partícipe da sociedade política. $\mathrm{O}$ cidadão passa a ser pessoa integrada na vida estatal. A cidadania é esse efetivo exercício político. O exercício da cidadania é mais amplo que o simples exercício dos direitos políticos, entretanto, aquele pressupõe a existência deste. Assim, só o titular dos direitos políticos pode exercer a cidadania plena.

Por exclusão, as pessoas jurídicas ficam impedidas de proporem a Ação Popular, segundo entendimento jurisprudencial já pacificado no Supremo Tribunal Federal a teor do enunciado da súmula 365 (STF, 1963): "Pessoa jurídica não tem legitimidade para propor ação popular".

Nesse contexto, o Ministério Público não possui legitimidade para propor uma ação popular. No que pese ser uma instituição essencial à promoção da justiça, - Ministério Público não se qualifica como cidadão, porém, sua participação é obrigatória na função de custos legis, conforme previsão da Lei n. ${ }^{\circ}$ 4.717/65 (BRASIL, 1965), artigo $6^{\circ} \S 4^{\circ}$, podendo assumir o feito no caso de desistência da parte autora, inclusive na execução de sentença condenatória. Devido a sua autonomia processual, o Ministério Público, após análise das provas nos autos, poderá opinar pela carência ou improcedência da ação.

Nos termos do artigo $1^{\circ}$ e artigo $6^{\circ}$ da Lei 4.717/65 (BRASIL, 1965), a legitimidade passiva na ação popular alcança todas as pessoas responsáveis direta 
ou indiretamente pelo ato jurídico guerreado. Mesmo sem uma previsão expressa na legislação pertinente, qualquer cidadão no exercício pleno de suas atividades políticas e que tenha interesse jurídico no resultado da lide, poderá atuar como assistente, tanto no polo ativo como no polo passivo, nos termos do Código de Processo Civil (BRASIL, 1973):

Art. 50. Pendendo uma causa entre duas ou mais pessoas, o terceiro, que tiver interesse jurídico em que a sentença seja favorável a uma delas, poderá intervir no processo para assisti-la.

Parágrafo único. A assistência tem lugar em qualquer dos tipos de procedimento e em todos os graus da jurisdição; mas o assistente recebe o processo no estado em que se encontra.

Uma importante peculiaridade da Ação Popular é a possibilidade do ente público demandado não contestar o pedido inicial, passando a atuar em consonância com o autor da lide, desde que fique resguardado o interesse público acima do interesse particular nos termos da Lei 4.717/65, artigo $6^{\circ}$, $\S 3^{\circ}$ (BRASIL, 1965). Nesse caso, a autoridade poderá promover por iniciativa própria a anulação do ato lesivo e antijurídico, conforme o entendimento jurisprudencial já sumulado pelo Supremo Tribunal Federal (STF):

\footnotetext{
Súmula $n^{\circ} 346$. A administração pública pode declarar a nulidade dos seus próprios atos.

Súmula $n^{\circ} 473$. A administração pode anular seus próprios atos, quando eivados de vícios que os tornam ilegais, porque deles não se originam direitos; ou revogá-los, por motivo de conveniência ou oportunidade, respeitados os direitos adquiridos, e ressalvada, em todos os casos, a apreciação judicial.
}

O lugar para a proposição da Ação Popular será o do lugar onde se originou o ato lesivo, sendo competente, inicialmente, a justiça comum de primeiro grau. Conforme disposição do artigo $5^{\circ}$ da Lei 4.717/65 (BRASIL, 1965), tratando-se de Estado e Município o procedimento será regulamentado pela organização judiciária do Tribunal Estadual. Sendo requerida a União, o procedimento será definido de acordo com o artigo 109 da Carta Magna (BRASIL, 1988).

Nesse entendimento já se pronunciou o Supremo Tribunal Federal:

AÇÃO ORIGINÁRIA. QUESTÃO DE ORDEM. AÇÃO POPULAR. COMPETÊNCIA ORIGINÁRIA DO SUPREMO TRIBUNAL FEDERAL: NÃOOCORRÊNCIA. PRECEDENTES. 1. A competência para julgar ação popular contra ato de qualquer autoridade, até mesmo do Presidente da 
República, é, via de regra, do juízo competente de primeiro grau. Precedentes. 2. Julgado o feito na primeira instância, se ficar configurado o impedimento de mais da metade dos desembargadores para apreciar o recurso voluntário ou a remessa obrigatória, ocorrerá a competência do Supremo Tribunal Federal, com base na letra $\mathrm{n}$ do inciso I, segunda parte, do artigo 102 da Constituição Federal. 3. Resolvida a Questão de Ordem para estabelecer a competência de um dos juízes de primeiro grau da Justiça do Estado do Amapá. (STF - AO-QO: 859 AP, Relator: ELLEN GRACIE, Data de Julgamento: 11/10/2001, Tribunal Pleno, Data de Publicação: DJ 01-08-2003 PP-00102 EMENT VOL-02117-16 PP-03213).

Deve ser ressaltada a exceção prevista pela Constituição Federal (BRASIL, 1988), a qual prevê a competência originária do Supremo Tribunal Federal nos termos do Art. 102, inciso I, alínea "n":

Art. 102. Compete ao Supremo Tribunal Federal, precipuamente, a guarda da Constituição, cabendo-Ihe: I processar e julgar, originariamente:

n) a ação em que todos os membros da magistratura sejam direta ou indiretamente interessados, e aquela em que mais da metade dos membros do tribunal de origem estejam impedidos ou sejam direta ou indiretamente interessados;

Esse posicionamento já é pacificado pela jurisprudência do Supremo Tribunal Federal:

DIREITO CONSTITUCIONAL ADMINISTRATIVO E PROCESSUAL CIVIL. AÇÃO POPULAR CONTRA TODOS OS MAGISTRADOS DO ESTADO DO ACRE. COMPETÊNCIA ORIGINÁRIA DO SUPREMO TRIBUNAL FEDERAL (ART. 102, I, N, DA C.F.). CABIMENTO DA AÇÃO. MEDIDA LIMINAR. GRATIFICAÇÃO DE NÍVEL UNIVERSITÁRIO AOS MAGISTRADOS DO ESTADO DO ACRE: ATO No 143/89, DE 20.07.1989, BAIXADO PELO PRESIDENTE DO TRIBUNAL DE JUSTIÇA. ART. 326 DO CÓDIGO DE ORGANIZAÇÃO JUDICIÁRIA DO ESTADO (L.C. N 47, DE 22.11.1995). QUESTÕES DE ORDEM. 1. A competência originária do Supremo Tribunal Federal é de ser reconhecida, em face do disposto no art. 102, I, n, da Constituição Federal, pois a Ação é proposta contra todos os Juízes do Estado do Acre, inclusive os Desembargadores do Tribunal de Justiça. 2. A Ação Popular é cabível, já que objetiva a suspensão definitiva do pagamento da Gratificação de Nível Superior e a consequente condenação dos beneficiários à devolução de todas as quantias recebidas, devidamente corrigidas. Com efeito, a Ação Popular, como regulada pela Lei $n^{\circ} 4.717$, de 29.06.1965, visa à declaração de nulidade ou à anulação de atos administrativos, quando lesivos ao patrimônio público, como dispõem seus artigos $1^{\circ}, 2^{\circ}$ e $4^{\circ}$.[.... 3 (STF AO: 506 AC, Relator: Min. SYDNEY SANCHES, Data de Julgamento: 06/05/1998, Tribunal Pleno, Data de Publicação: DJ 04-12-1998 PP-00010 EMENT VOL-01934-01 PP-00022).

O procedimento legal segue subsidiariamente ao rito ordinário previsto no Código de Processo Civil, devendo ser ressaltados os prazos processuais diferenciados estabelecidos pela Lei 4.717/65. Cabível, também, a apreciação de pedido liminar se presentes os requisitos do fumus boni iuris e o periculum in mora. 
Havendo procedência do pedido, o ato questionado será declarado inválido, produzindo efeitos erga omnes, protegendo o bem tutelado. No caso de improcedência é necessário uma análise das circunstancias a fim de definir o alcance dos efeitos da sentença. Nesse sentido, enfatiza Moraes (2009, p. 187):

\begin{abstract}
Se a ação popular for julgada improcedente por ser infundada, a sentença produzirá efeitos de coisa julgada erga omnes, permanecendo válido o ato. Porém, se a improcedência decorrer de deficiência probatória, apesar da manutenção da validade do ato impugnado, a decisão de mérito não terá eficácia de coisa julgada erga omnes, havendo possibilidade de ajuizamento de uma nova ação popular com o mesmo objeto e fundamento, por prevalecer o interesse público de defesa da legalidade e da moralidade administrativas, em busca da verdade real (MORAES, 2009, p. 187).
\end{abstract}

\title{
2.2.2 Ação civil pública
}

A ação civil pública (ACP) como instrumento processual, inicialmente instituído para defesa dos direitos difusos, coletivos e individuais homogêneos, tornou-se uma ferramenta jurídica apta para proteger os direitos sociais, redirecionando as decisões administrativas fixadas pela administração pública. Como instrumento processual constitucional, promove a legitimação do Ministério Público (BRASIL, 1988), com o objetivo de fiscalizar e coibir os atos de improbidade administrativa danosos aos interesses difusos e coletivos da sociedade.

Art. 129. São funções institucionais do Ministério Público:

III - promover o inquérito civil e a ação civil pública, para a proteção do patrimônio público e social, do meio ambiente e de outros interesses difusos e coletivos;

Esse dispositivo processual possui mecanismos adequados para cessar ou prevenir atos lesivos aos bens e direitos de valor artístico, estético, paisagístico, histórico, turístico e ao meio ambiente, assim como nas infrações de ordem econômica, inclusive no direito do consumidor. Busca a proteção do bem tutelado, impondo a aplicação das sanções previstas no artigo $37, \S 4^{\circ}$, da Constituição Federal (BRASIL, 1988), e exigindo uma reparação do dano causado ao patrimônio público ou ao direito lesado.

Victor (2008, p. 1) destaca a asserção da ação civil pública como um divisor de águas no que tange à tutela jurisdicional coletiva no Brasil, in verbis: 
De fato, com ela despontaram as primeiras experiências no campo da legitimidade de agir, por substituição social, especialmente em prol de direitos difusos e coletivos. Conforme restará esmiuçado em tópico sucessivo, desde a sua introdução em 1985 (Lei $n^{\circ} 7.347$ ), a ação civil pública ganhou corpo e espaço, sendo hoje um dos instrumentos processuais coletivos mais disseminados e versáteis.

Mendes (2007) enfatiza que, em uma sociedade moderna, o processo coletivo surge como fenômeno natural de superação do modelo individual de direitos subjetivos, revelando-se, inclusive, como autêntico corolário do princípio da economia processual.

A ação civil pública inovou como instrumento jurídico de Controle Social e institucional. Tem como objetivo a cessação ou prevenção de atos ou políticas públicas que causem danos ao consumidor, ao patrimônio público, com destinação específica, não podendo ser proposta em defesa de direitos particulares ou disponíveis. Foi regulamentada pela Lei n. 7.347/85 (BRASIL, 1985):

Art. $1^{\circ}$ Regem-se pelas disposições desta Lei, sem prejuízo da ação popular, as ações de responsabilidade por danos morais e patrimoniais causados.

I - ao meio-ambiente;

II - ao consumidor;

III - a bens e direitos de valor artístico, estético, histórico, turístico e paisagístico;

IV - a qualquer outro interesse difuso ou coletivo.

$V$ - por infração da ordem econômica;

$\mathrm{VI}$ - à ordem urbanística;

VII - à honra e à dignidade de grupos raciais, étnicos ou religiosos;

VIII - ao patrimônio público e social.

O objeto da ação civil pública é a defesa dos direitos protegidos pela Constituição Federal e as Leis especiais, podendo ter como fulcro jurídico a inconstitucionalidade de Lei, norma ou ato ilegal lesivo à coletividade, tendo como resultado dano ao meio ambiente, ao consumidor, a bens e direitos de valor artístico ou de interesse difuso e coletivos.

Nesse sentido, enfatiza Aguiar JR. (1995, p. 23) que os pedidos propostos em sede de uma ação civil pública devem estar em concordância com o artigo $3^{\circ}$ da Lei 7.347/85, quanto à obrigação de fazer ou de não fazer, assim como a condenação em dinheiro:

A ação civil pública pode ser usada para fins de obter a) uma condenação em dinheiro, destinada a indenizar o dano já causado, ou b) a cominação para fazer ou não o fazer algo. Na ação que tenha por objeto obrigação de 
fazer ou não fazer, o juiz determinará o cumprimento da prestação ou da atividade devida, ou a cessação da atividade nociva, sob pena de execução específica ou de cominação de multa diária (astreintes), se esta for suficiente e compatível, independentemente de requerimento do autor.

Em defesa disso, Amaral (2001, p. 214) enfatiza:

\begin{abstract}
As prestações positivas são exigíveis pelo cidadão, havendo dever do Estado ou de entregar a prestação, através de um dar ou fazer, ou de justificar porque não o faz. Esta justificativa será apenas a existência de circunstâncias concretas que impedem 0 atendimento de todos que demandam prestações essenciais e, assim, tornam inexoráveis escolhas trágicas, conscientes ou não. Estando presentes circunstâncias desse tipo, haverá espaço de escolha, no qual o Estado estabelecerá critérios de alocação dos recursos e, consequentemente, de atendimento às demandas, o que tornará legítima a não entrega da prestação demandada para aqueles que não estão enquadrados nos critérios.
\end{abstract}

Isso posto, defende-se que a ação civil pública não deveria ser proposta pelo Ministério Público exclusivamente com o objetivo de ressarcimento de prejuízos ao erário público, pois isso não preencheria suas finalidades sociais. Nesse entendimento, Barroso (2006, p. 223) indica que "a alternatividade que o dispositivo enseja não impede a cumulação, numa mesma ação, dos pedidos de prestar ou não algum fato e de indenizar em certa quantia de dinheiro".

No que pese a regulamentação dada à ação civil pública pela LACP (Lei de ação civil pública - BRASIL, 1985), existem outras normas concorrentes que orientam o emprego dessa ação em outras diferentes aplicações. No ano de 1990, com a vigência do Código de Defesa do Consumidor (CDC - BRASIL, 1990), o artigo 117 alterou o artigo 21 da Lei 7.347/85 (BRASIL, 1985), modificando a regulamentação da ação civil pública e adotando procedimento similar às ações coletivas de defesa do consumidor, no que for cabível:

Art. 21. Aplicam-se à defesa dos direitos e interesses difusos, coletivos e individuais, no que for cabível, os dispositivos do Título III da Lei que instituiu o Código de Defesa do Consumidor.

Com esta alteração, prevalece a regulamentação dada pelo artigo 81 do CDC (BRASIL, 1990), o qual indica os casos de defesa de interesse difuso, coletivo e individual homogêneo:

Art. 81. A defesa dos interesses e direitos dos consumidores e das vítimas poderá ser exercida em juízo individualmente, ou a título coletivo. 
Parágrafo único. A defesa coletiva será exercida quando se tratar de:

I - interesses ou direitos difusos, assim entendidos, para efeitos deste Código, os transindividuais, de natureza indivisível, de que sejam titulares pessoas indeterminadas e ligadas por circunstâncias de fato;

II - interesses ou direitos coletivos, assim entendidos, para efeitos deste Código, os transindividuais de natureza indivisível de que seja titular grupo, categoria ou classe de pessoas ligadas entre si ou com a parte contrária por uma relação jurídica-base;

III - interesses ou direitos individuais homogêneos, assim entendidos os decorrentes de origem comum.

Dessa forma, o CDC e a LACP devem ser usados concomitantemente ao nortear o processo de defesa dos interesses transindividuais e individuais homogêneos com aplicação subsidiária no procedimento.

Almeida (2003) assinala que com o surgimento do CDC, a ação civil pública alçou contornos muito mais amplos, consubstanciando verdadeiro microssistema de tutela dos direitos e interesses coletivos e abarcando não só os direitos coletivos em sentido estrito e difusos, mas também os direitos individuais homogêneos.

\subsubsection{Procedimento}

O Ministério Público possui legitimação direta da Constituição Federal (BRASIL, 1988), contudo a regulamentação dada pela Lei 7.347/85 (BRASIL, 1985) amplia de modo significativo as instituições que podem figurar no polo ativo da demanda:

Art. $5^{\circ}$ Têm legitimidade para propor a ação principal e a ação cautelar: (Redação determinada na Lei $n^{\circ} 11.448$, de 15.1.2007, DOU 16.1.2007)

I - o Ministério Público;

II - a Defensoria Pública;

III - a União, os Estados, o Distrito Federal e os Municípios;

IV - a autarquia, empresa pública, fundação ou sociedade de economia mista;

$\mathrm{V}-\mathrm{a}$ associação que, concomitantemente:

a) esteja constituída há pelo menos 1 (um) ano nos termos da Lei civil;

b) inclua, entre suas finalidades institucionais, a proteção ao meio ambiente, ao consumidor, à ordem econômica, à livre concorrência ou ao patrimônio artístico, estético, histórico, turístico e paisagístico.

Nesses termos, a ação civil pública pode ser proposta pelo Ministério Público, pela União, pelos Estados, Municípios, Distrito Federal, assim como as empresas públicas, fundações, sociedades de economia mista e associações. No caso de desistência infundada do processo, o Ministério Público ou qualquer outro legitimado poderá prosseguir no feito. 
É importante ressaltar que a legislação pertinente não limita a legitimidade no polo passivo da demanda, com isso é possível propor a ação em relação a quaisquer pessoas físicas ou jurídicas, de direito público ou privado.

Santos (2000) ressalta a peculiaridade da ação civil pública quanto à legitimação extraordinária no polo ativo, o que permite que se postule, em nome próprio, direito alheio, permitindo excepcionalmente que a ação seja proposta por quem não é o titular do direito material.

Alvim (2005) ressalta que a inclusão dos direitos individuais homogêneos deve observar algumas restrições pertinentes ao Ministério Público, o qual só deve intentar a ação civil pública com o objetivo de proteger direitos indisponíveis, como descrito no art. 127 da Constituição Federal (BRASIL, 1988).

O lugar competente para proposição da ação civil pública, assim como a ação cautelar, é em regra o local onde ocorreu o dano, salvo legislação especial ou a prevenção por outro juízo, conforme previsto no artigo $2^{\circ}$ da Lei 7.347/85 (BRASIL, 2005).

Art. $2^{\circ}$ As ações previstas nesta Lei serão propostas no foro do local onde ocorrer dano, cujo juízo terá competência funcional para processar e julgar a causa.

Parágrafo único. A propositura da ação prevenirá a jurisdição do juízo para todas as ações posteriormente intentadas que possuam a mesma causa de pedir ou o mesmo objeto.

A ação civil pública pode ser proposta sob o rito ordinário ou sumário do processo civil, podendo, ainda, conter pedido liminar cautelar ou de tutela antecipada, desde que presentes os requisitos de aparência do bom direito e do perigo da demora.

Quanto à possibilidade de antecipação de tutela, existem divergências doutrinárias. No entendimento de Meirelles (2003), a LACP estabeleceu um procedimento ao pedido liminar, não se aplicando a Lei geral. Para outros doutrinadores, assim como ensina Barroso (2003), é possível o pedido de tutela antecipada nos casos das ações em que tenham por objeto a obrigação de fazer ou não fazer.

Com a previsão de aplicação subsidiária do Código de Processo Civil (CPC - BRASIL, 1973), dada pelo artigo 19 da LACP, possibilita a proposição de ação cautelar preparatória ou incidental: 
Aplica-se à ação civil pública, prevista nesta Lei, o Código de Processo Civil, aprovado pela Lei $n^{\circ} 5.869$, de 11 de janeiro de 1973, naquilo em que não contrarie suas disposições.

Julgado procedente o pedido, o administrador público deverá sanar o ato impugnado, retornando ao estado anterior, respondendo ainda por possíveis danos patrimoniais. Sendo a sentença julgada improcedente, somente produzirá efeito jurídico após a confirmação em segunda instância, que deverá ser de ofício, caso as partes não apresente o recurso.

\subsubsection{Conselho de Saúde}

O Conselho de Saúde constitui um instrumento de Controle Social, por intermédio da participação permanente da sociedade no desenvolvimento e fiscalização das políticas públicas de saúde. Como instrumento de democracia participativa, possui previsão legal no artigo 198, inciso III, da Constituição Federal (BRASIL, 1988, grifo nosso).

Art. 198. As ações e serviços públicos de saúde integram uma rede regionalizada e hierarquizada e constituem um sistema único, organizado de acordo com as seguintes diretrizes:

I - descentralização, com direção única em cada esfera de governo;

II - atendimento integral, com prioridade para as atividades preventivas, sem prejuízo dos serviços assistenciais;

III - participação da comunidade.

Em atendimento aos dispositivos constitucionais referentes ao setor saúde, o legislador infraconstitucional estabeleceu as Conferências de Saúde e os Conselhos de Saúde nas respectivas esferas de governo (federal, estadual, municipal e distrital), como órgãos deliberativos e permanentes, consolidando a gestão participativa do SUS. A criação desses mecanismos norteadores das políticas públicas de saúde consolida a democracia participativa, conforme assevera Moraes (2006, p. 131 e 132):

A consagração de um Estado Democrático pretende, precipuamente, afastar a tendência humana ao autoritarismo e concentração de poder. [...] Assim, o princípio democrático exprime fundamentalmente a exigência da integral participação de todos e de cada uma das pessoas na vida política do país, a fim de garantir-se o respeito à soberania popular.

Como defende Gurza e Isunza (2011) a participação na tomada de decisões tem o potencial de desenvolver no cidadão o sentimento de corresponsabilidade 
junto à sociedade, que além de motivar a formação de identidades sociais amplas, também colabora para a legitimação das instituições políticas. Os Conselhos de Saúde atuam como corresponsáveis das políticas públicas, conforme previsto pela Constituição Federal de 1988, emoldurado com as prerrogativas e garantias legais.

Ferreira (2000, p. 208) enaltece o princípio da democracia participativa, representada pelo Conselho de Saúde, como exercício do sistema democrático de governo:

Governo do povo; soberania popular. Doutrina ou regime político baseado nos princípios da soberania popular e da distribuição equitativa do poder.

Participação popular quer dizer: 1.informar, comunicar. 2. ter ou tomar parte em. 3. ter parcela em um todo.

Conforme descreve o Ministério da Saúde (BRASIL, 2006, p. 94), o Conselho de Saúde é um órgão colegiado de caráter permanente com função deliberativa e de gestão compartilhada do SUS, em cada esfera de governo, disponibilizando à sociedade civil organizada um modelo concreto de Controle Social:

\begin{abstract}
Abrange as práticas de fiscalização e de participação nos processos deliberativos relacionados à formulação de políticas de saúde e de gestão no SUS. Há mecanismos institucionalizados que garantem a participação e - Controle Social, como os Conselhos de Saúde e as Conferências de Saúde, com representatividade dos diversos atores sociais. As Conferências de Saúde, que ocorrem a cada dois anos, devem avaliar o cumprimento das diretrizes contidas no respectivo Plano de Saúde e produzir diretrizes que orientem novas políticas e programas no seu âmbito de atuação. Conselhos e conferências são garantidos nas três esferas de gestão do SUS pela Lei n. 8.142 de 28 de dezembro de 1990. O SUS garante aos estados, ao Distrito Federal e aos municípios autonomia para administrar os recursos da Saúde. Para isso, é preciso que cada esfera de gestão tenha seu Conselho de Saúde funcionando de forma adequada. Ao Ministério da Saúde (MS) e às secretarias estaduais e municipais de Saúde cabe a implementação de mecanismos para a gestão e apoio ao fortalecimento do Controle Social no SUS.
\end{abstract}

Gonçalves e Almeida (2002, p. 168) enaltecem o Conselho de Saúde como órgão colegiado que possui um ambiente propício para o debate de ideias e para defesa de interesses dos diversos segmentos sociais ali representados, a fim de propiciar políticas públicas de saúde mais abrangentes:

[...] são espaços de conflito e integram os atores com diferentes projetos e interesses. Mas são também possíveis espaços onde os sujeitos sociais podem, através do Controle Social, exercer a cidadania, o poder participativo 
e construírem sujeitos políticos com capacidade e potência para intervir positivamente na implementação do SUS no nível local.

Moreira (2007) observa que os Conselhos de Saúde são novidade política, muito distintas daquelas tradicionais, ainda que em processo de desenvolvimento. São instituições que estão sendo estabelecidas como uma participação não política eleitoral ou partidária, de representação extraparlamentar, o que indica um processo de pluralização da representação, como experiências de inovação democrática. 0 surgimento desses novos sujeitos sociopolíticos modificou a maneira de fazer política das entidades organizadas e da própria gestão pública.

Outro doutrinador que engrandece as atribuições do Conselho de Saúde por sua abrangência e representatividade social é Carvalho (1995, p. 104), que o identifica como marco histórico:

Nada há, na história do Estado Brasileiro, que se assemelhe aos Conselhos de Saúde da atualidade, seja pela representatividade social que expressam, seja pela gama de atribuições e poderes legais de que são investidos, seja pela extensão em que estão implantados por todo o país, nas três esferas governamentais.

Para Dallari et al. (1996), os Conselhos são instâncias de ação política que articulam as ações do Estado e da cidadania, com objetivo de fazer prevalecer o interesse social na gestão pública do SUS. Com essa estruturação, observa-se que o Controle Social adquiriu materialidade, contribuindo de forma prática para a democratização das relações entre Estado e sociedade.

Na lição de Gama (2006, p. 131), a democracia participativa é a "forma de governo em que o povo controla diretamente a gestão da sociedade", ou seja, é quando a vontade social é exercida diretamente na tomada de decisões, o que acontece na atribuição deliberativa do Conselho de Saúde. Corroborando esse posicionamento, Dallari (1990, p. 31) afirma que:

Primeiramente a Democracia surge como um processo de democratização entendido como processo de aprofundamento democrático da ordem política, econômica, social e cultural. Depois, o princípio democrático recolhe as duas dimensões historicamente consideradas como antitéticas: por um lado, acolhe os mais importantes elementos da teoria democrática representativa (órgãos representativos, eleições periódicas, pluralismo partidário, separação de poderes); por outro lado, dá guarida a algumas exigências fundamentais da teoria participativa (alargamento do princípio democrático a diferentes aspectos da vida econômica, social e cultural, incorporação de participação popular direta e conhecimento de partidos e associações como relevantes agentes de dinamização democrática). 
Essa doutrina defende que a verdadeira democracia só é possível com a participação efetiva e direta do povo na gestão da coisa pública. Essa participação se estabelece como um princípio fundamental da democracia participativa, conforme afirma Bobbio (2002, p. 68 e 69):

Hoje, se se deseja apontar um indicador de desenvolvimento democrático, este não pode mais ser o número de pessoas que têm o direito de votar, mas o número de locais, diferentes dos locais políticos nos quais se exerce o direito de voto; sintética mas eficazmente: para dar um juízo sobre o Estado de democratização, num dado país, o critério não deve ser mais o de "quem" vota, mas o do "onde" se vota (e fique claro que aqui entendo o "votar" como ato típico e mais comum do participar, mas não pretendo de forma alguma limitar a participação ao voto).

Segundo Coelho (2004), o desempenho dessa participação social inovadora, resultante do processo de redemocratização política, especialmente após a promulgação da Constituição Federal de 1988, tem sido influenciado por fatores socioculturais históricos, como a falta de tradição e cultura nacional nas atividades de coparticipação na gestão pública.

\subsubsection{Regulamentação}

Em que pese a menção ao Conselho de Saúde na Lei n. 8080 de 19 de setembro de 1990 (BRASIL, 1990, grifos nossos), chamada Lei Orgânica da saúde, nos artigos 12; 26; 33 e 37, o mesmo foi instituído e regulamentado somente a posteriori:

Art. 12 Serão criadas comissões intersetoriais de âmbito nacional, subordinadas ao Conselho Nacional de Saúde, integradas pelos Ministérios e órgãos complementares e por entidades representativas da sociedade civil.

Art. 26 Os critérios e valores para a remuneração de serviços e os parâmetros de cobertura assistencial serão estabelecidos pela direção nacional do Sistema Único de Saúde SUS, aprovados no Conselho Nacional de Saúde.

Art. 33 Os recursos financeiros do Sistema Único de Saúde - SUS serão depositados em conta especial, em cada esfera de sua atuação, e movimentados sob fiscalização dos respectivos Conselhos de Saúde.

Art. 37 - O Conselho Nacional de Saúde estabelecerá as diretrizes a serem observadas na elaboração dos planos de saúde, em função das características epidemiológicas e da organização dos serviços em cada jurisdição administrativa. 
Embora a Lei 8.080/90 (BRASIL, 1990) indicasse o Conselho de Saúde como órgão de gestão do SUS, não apresentou qualquer regulamentação, cabendo posteriormente à Lei Federal n. 8.142 de 28 de dezembro de 1990 (BRASIL, 1990), instituir seu funcionamento.

O Conselho de Saúde tem atribuição legal para atuar diretamente na elaboração das políticas públicas de saúde de maneira autônoma em relação ao gestor. Somente dessa forma é possível defender os interesses dos diversos segmentos sociais representados. Fazem parte das atribuições do Conselho de Saúde: o planejamento e a fiscalização da execução dos programas de saúde; a deliberação e aprovação das prestações de contas, conforme estabelece a Lei federal $n^{\circ} 8.142 / 90$ (BRASIL, 1990).

No artigo $1^{\circ}$ da norma citada, estabelece a instituição da Conferência de Saúde e do Conselho de Saúde em cada esfera de governo, sem prejuízo das atribuições do Poder Legislativo.

Atribui, no parágrafo $2^{\circ}$, o caráter permanente e deliberativo do Conselho de Saúde como órgão colegiado composto por representantes da administração pública, prestadores de serviço, profissionais de saúde e usuários:

\footnotetext{
Art. $1^{\circ} \mathrm{O}$ Sistema Único de Saúde (SUS), de que trata a Lei ${ }^{\circ} 8.080$, de 19 de setembro de 1990, contará, em cada esfera de governo, sem prejuízo das funções do Poder Legislativo, com as seguintes instâncias colegiadas: I - a Conferência de Saúde; e II - o Conselho de Saúde.

$\S 2^{\circ} \mathrm{O}$ Conselho de Saúde, em caráter permanente e deliberativo, órgão colegiado composto por representantes do governo, prestadores de serviço, profissionais de saúde e usuários, atua na formulação de estratégias e no controle da execução da política de saúde na instância correspondente, inclusive nos aspectos econômicos e financeiros, cujas decisões serão homologadas pelo chefe do poder legalmente constituído em cada esfera do governo.
}

O Conselho de Saúde é composto por usuários do SUS, prestadores de serviço da área da saúde e representantes da administração pública. A representação dos usuários do SUS deve ser paritária (50\%) em relação ao conjunto dos demais segmentos, sendo o seu funcionamento definido por regimento próprio, nos termos do artigo $1^{\circ}$ e $\S 4^{\circ}$, da Lei 8.142/90 (BRASIL, 1990): 
A Lei condiciona o repasse de verbas federais destinadas à saúde à existência do Conselho de Saúde, conforme determina o artigo $4^{\circ}$, inciso II, parágrafo único, da Lei citada, in litteris:

Art. $4^{\circ}$ Para receberem os recursos, de que trata o art. $3^{\circ}$ desta Lei, os Municípios, os Estados e o Distrito Federal deverão contar com:

[...]

II - Conselho de Saúde [...]

Parágrafo único. O não atendimento pelos Municípios, ou pelos Estados, ou pelo Distrito Federal, dos requisitos estabelecidos neste artigo, implicará em que os recursos concernentes sejam administrados, respectivamente, pelos Estados ou pela União.

Dessa forma, a instituição dos Conselhos Estaduais e Municipais de Saúde não é uma decisão discricionária, mas sim uma exigência imposta pela Constituição e pelas Leis 8.080/90 e 8.142/90 (BRASIL, 1990) como exercício da democracia participativa. Acerca do tema, Vázquez (2005, p.151) afirma:

No Brasil, a participação da população é um dos eixos principais na estruturação do Sistema Único de Saúde (SUS) e está claramente definida dentro do marco legal da reforma do setor saúde (Constituição Federal, 1988; Leis 8.080 e 8.142, 1990; NOB's 1/91, $1 / 92$ e 1/96). A Constituição Federal estabelece que é um direito e um dever de todo cidadão participar em todos os níveis de governo. Este novo marco legal recolhe uma concepção democrática da participação em saúde, significando a integração, em parceria com o Estado, dos diferentes setores da população na definição de políticas de saúde a serem implementadas, bem como no monitoramento de sua implementação, incluindo aspectos econômicos e financeiros.

\subsubsection{Atribuições e competência}

O Conselho de Saúde tem como atribuição a coparticipação na definição de metas e diretrizes das políticas públicas, bem como na elaboração dos planos e programas de saúde. Como instrumento de Controle Social, possui a função de análise e aprovação dos contratos e convênios, assim como a deliberação e aprovação da proposta orçamentária anual da saúde, conforme o disposto na Lei de Diretrizes Orçamentárias, nos termos do artigo 195 , parágrafo $2^{\circ}$, da Lei Maior (BRASIL, 1988),

Art. 195. A seguridade social será financiada por toda a sociedade, de forma direta e indireta, nos termos da Lei, mediante recursos provenientes dos orçamentos da União, dos Estados, do Distrito Federal e dos Municípios, e das seguintes contribuições sociais: 
$\S 2^{\circ} \mathrm{A}$ proposta de orçamento da seguridade social será elaborada de forma integrada pelos órgãos responsáveis pela saúde, previdência social e assistência social, tendo em vista as metas e prioridades estabelecidas na Lei de diretrizes orçamentárias, assegurada a cada área a gestão de seus recursos.

O planejamento e o orçamento do setor saúde também devem considerar o disposto no artigo 36 da Lei n. 8.080 de 19 de setembro de 1990 (BRASIL, 1990).

Art. 36. O processo de planejamento e orçamento do Sistema Único de Saúde (SUS) será ascendente, do nível local até o federal, ouvidos seus órgãos deliberativos, compatibilizando-se as necessidades da política de saúde com a disponibilidade de recursos em planos de saúde dos Municípios, dos Estados, do Distrito Federal e da União.

As atribuições do Conselho de Saúde englobam: a fiscalização e o controle das despesas; acompanhamento da execução dos serviços de saúde; participação na elaboração dos programas de saúde, assim como a escolha das prioridades de uso dos recursos financeiros; análise e aprovação do relatório de gestão, com a respectiva prestação de contas, dentre outras. Essas atribuições estão dispostas na Lei Complementar 141/12 (BRASIL, 2012, grifos nossos)

Art. 36 - O gestor do SUS em cada ente da Federação elaborará Relatório detalhado referente ao quadrimestre anterior, o qual conterá, no mínimo, as seguintes informações:

$\S 1^{\circ}$ - A União, os Estados, o Distrito Federal e os Municípios deverão comprovar a observância do disposto neste artigo mediante o envio de

Relatório de Gestão ao respectivo Conselho de Saúde, até o dia 30 de março do ano seguinte ao da execução financeira, cabendo ao Conselho emitir parecer conclusivo sobre o cumprimento ou não das normas estatuídas nesta Lei Complementar, ao qual será dada ampla divulgação, inclusive em meios eletrônicos de acesso público, sem prejuízo do disposto nos arts. 56 e 57 da Lei Complementar $n^{\circ}$ 101, de 4 de maio de 2000.

$\S 2^{\circ}$ - Os entes da Federação deverão encaminhar a programação anual do Plano de Saúde ao respectivo Conselho de Saúde, para aprovação antes da data de encaminhamento da Lei de diretrizes orçamentárias do exercício correspondente, à qual será dada ampla divulgação, inclusive em meios eletrônicos de acesso público.

O sistema de fiscalização e controle instituído por meio do Conselho de Saúde é amplo e abrange todas as etapas do sistema de saúde. Tem início com a elaboração das diretrizes das políticas públicas se desenvolvendo até a efetiva prestação de contas, conforme previsto na LC 141/12 (BRASIL, 2012): 
Art. 41 - Os Conselhos de Saúde, no âmbito de suas atribuições, avaliarão a cada quadrimestre o relatório consolidado do resultado da execução orçamentária e financeira no âmbito da saúde e o relatório do gestor da saúde sobre a repercussão da execução desta Lei Complementar nas condições de saúde e na qualidade dos serviços de saúde das populações respectivas e encaminhará ao Chefe do Poder Executivo do respectivo ente da Federação as indicações para que sejam adotadas as medidas corretivas necessárias.

\subsubsection{Desempenho das atividades}

Sposati e Lobo (1992) apontam a imaturidade social no momento da instituição dos Conselhos de Saúde como motivo dos resultados módicos de sua atuação. Apesar de ter formado uma extensa rede de participação social, não propiciou resultados efetivos nos diversos segmentos sociais. O ganho quantitativo não proporcionou uma melhora qualitativa na participação popular na saúde.

Outros autores que avaliam o desempenho dos Conselhos de Saúde apresentaram as atividades da instituição como "proforma", apenas com a finalidade de satisfazer as exigências legais, como apresenta Martins et al. (2013, p. 438):

Dentro do processo de descentralização da saúde, a criação dos Conselhos de Saúde passou a ser uma exigência para o repasse de recursos da esfera federal para as esferas estaduais e municipais. Diante disso, criaram-se muitos Conselhos como mera formalidade para viabilizar o recebimento dos recursos. Esses Conselhos, forjados pelo Estado, caracterizam-se majoritariamente pela manipulação de sua composição, ingerência dos gestores e atuação inexpressiva no sentido de aprovar documentos para repasse de recursos.

Com essa perspectiva, Martins et al. (2013) enfatizam que esses órgãos pouco influenciam na definição das políticas de saúde. Para eles, essa situação é uma consequência da tradição autoritária histórica do Estado brasileiro; da fragilidade e falta de cultura da vida associativa; e da própria resistência ou dificuldade dos participantes sociais em apresentar uma discussão. Martins et al. (2013, p.439) descrevem:

Dentro dos Conselhos, os próprios representantes dos segmentos dos usuários e dos trabalhadores, destituídos de tantos recursos quanto os que têm os representantes das classes hegemônicas, cumprem, em sua maioria, papel meramente formal. [...]

O conhecimento, sujeito a tais distorções, distanciado da ideologia e dos interesses dos segmentos representados, limita a possibilidade de intervenção autônoma e a possibilidade de uma real representatividade no Conselho. 
Grisotti et al. (2010, p.835) em pesquisa em Florianópolis, Santa Catarina, com uma abordagem qualitativa, a qual teve como objetivo analisar a efetividade das ações do SUS e a participação efetiva do Conselho Municipal de Saúde, constataram o baixo desempenho da participação popular:

\begin{abstract}
Apesar de esses mecanismos de participação social, nesses últimos anos, serem enfatizados tanto na literatura acadêmica quanto nas políticas públicas (muitas vezes pressionadas por agências internacionais), observa-se que os mesmos permanecem ainda como um ideal a ser atingido. Mesmo que tenham ocorrido no Brasil várias experiências de participação popular, muitas não tiveram continuidade devido à falta de uma estrutura institucional que as apoiasse numa perspectiva de longo prazo e, também, à falta de uma cultura participativa no interior da sociedade.
\end{abstract}

Mesmo considerando que a instituição dos Conselhos seja resultado de uma obrigação legal e administrativa originada na esfera federal, Luchmann (2002, p.43) em seu estudo sobre as experiências dos Conselhos gestores de políticas públicas, aponta que a "obrigatoriedade legal" da participação da população configura um quadro de ambiguidade, enfatizando que:

por um lado, essa obrigatoriedade é responsável pela implementação de uma série de experiências conselhistas que se institucionalizam sem ou com reduzido respaldo de mobilização e participação social, o que os torna espaços com caráter meramente formal-legal. Por outro lado, essa obrigatoriedade permite, por não depender única e exclusivamente do projeto político do governo, uma maior explicitação dos conflitos sociais. $O$ embate entre a sociedade civil, ou setores desta, e o Estado no interior de várias experiências conselhistas é um indicador importante de que, ancorados em um estatuto legal, os Conselhos podem não apenas provocar importantes ruídos tendo em vista questionar os mecanismos de poder tradicionais, como alterar condições e realidades sociais.

Outro aspecto do Controle Social por meio dos Conselhos de Saúde destacado da pesquisa realizada por Grisotti et al. (2010, p.836) enfatizam o fato de que as Assembleias realizadas para a deliberação e aprovação das prestações de contas do gestor público cumprem apenas mera formalidade, sem um debate sobre os temas apresentados:

Os Conselhos de Saúde, portanto, foram criados para propiciar a participação visando ao Controle Social no uso dos recursos públicos. Entretanto, no contexto em estudo, encontramos deficiências na sua dinâmica de funcionamento, nos encaminhamentos das deliberações, no papel do conselheiro e na sua relação com a entidade que ele representa, e até na composição e representatividade dos conselheiros. 
Em relação à dinâmica de funcionamento do Conselho, percebe-se uma frustração em relação aos resultados obtidos (a resolutividade de suas atividades) diante do longo tempo despendido em reuniões demoradas e dispersas, especialmente aquelas sobre prestações de contas, cujos relatórios, geralmente, vinham prontos da Secretaria para serem aprovados na reunião.

Guizardi e Pinheiro (2006, p. 798) destacam que mesmo considerando a composição paritária dos usuários do sistema de saúde em $50 \%$ da composição dos membros do Conselho de Saúde, as diferenças sociais podem pender as decisões em favor dos gestores:

Propõe discutir como se concretiza essa participação, já que a presença quantitativa assegurada com o requisito jurídico da paridade não significa uma correspondência direta com a capacidade de intervenção [...]

Nesse sentido, mesmo a formalização igualitária assegurada pelo reconhecimento comum dos direitos civis e políticos (sem mencionar os direitos sociais) revelou-se inconsistente, já que permanentemente submetida a um padrão de dominação social caracterizado por absurdos hiatos e desigualdades entre as classes populares e os setores médios e altos da população.

Ao analisar o desempenho dos Conselhos de Saúde, Gerschman (2004, p.1673) questiona o peso político dos conselheiros no desempenho de suas funções:

Por sua vez, os conselheiros representantes da sociedade nos Conselhos perderam a base política de sustentação sobre a qual tinha se forjado a identidade e a mobilização política características do movimento popular em saúde. Cabe então se perguntar: qual o papel político dos Conselhos? Que Controle Social exercem, entendido este como vigilância da sociedade organizada sobre as ações de governo? Qual a natureza da representação social exercida pelo conselheiro, a sua configuração dentro da esfera pública e seu tipo de mandato? Qual a efetividade do Conselho, levando em consideração sua composição, criação e funcionamento? [...].

No início da implantação dos Conselhos, os conselheiros exerciam uma função que se originava na delegação política que a comunidade lhe outorgava. Isso não se dava sem confronto entre projetos oriundos das múltiplas organizações populares então atuantes.

\subsection{Agente público}

É essencial a conceituação de agente público a fim de definir as pessoas alcançadas pela legislação que regulamenta o serviço público, assim como a sujeição às penalidades previstas pelas Leis pertinentes. 
A definição de agente público alcança todo indivíduo que exerça, ainda que temporariamente ou mesmo sem remuneração, qualquer função pública, seja por eleição, nomeação, designação, contratação ou qualquer outra forma de investidura ou vínculo com o ente público, empresa incorporada ao patrimônio público ou de entidade para cuja criação ou custeio o erário haja concorrido ou concorra com mais de cinquenta por cento do patrimônio ou da receita anual, nos termos dos art. $1^{\circ}$ e $2^{\circ}$ da Lei n 8.429, de 1992 (BRASIL, 1992):

\begin{abstract}
Art. $1^{\circ}$ Os atos de improbidade praticados por qualquer agente público, servidor ou não, contra a administração direta, indireta ou fundacional de qualquer dos Poderes da União, dos Estados, do Distrito Federal, dos Municípios, de Território, de empresa incorporada ao patrimônio público ou de entidade para cuja criação ou custeio o erário haja concorrido ou concorra com mais de $50 \%$ (cinquenta por cento) do patrimônio ou da receita anual, serão punidos na forma desta Lei.

Art. $2^{\circ}$ Reputa-se agente público, para os efeitos desta Lei, todo aquele que exerce, ainda que transitoriamente ou sem remuneração, por eleição, nomeação, designação, contratação ou qualquer outra forma de investidura ou vínculo, mandato, cargo, emprego ou função nas entidades mencionadas no artigo anterior.
\end{abstract}

A tipificação dada pela Lei $n^{\circ}$. 8.429/92 (BRASIL, 1992) prevê que, além dos servidores públicos propriamente definidos, também são passivos da prática de atos de improbidade qualquer outro agente público no exercício de suas atribuições, seja por mandato, cargo, qualquer forma de vínculo, emprego ou função nas entidades que são consideradas como sujeitos passivos de improbidade.

Os atos de improbidade administrativa podem ser praticados, também, por particular que, de alguma forma, concorra ou dele se beneficie, conforme previsão do art. $3^{\circ}$ da Lei 8.429/92 (BRASIL, 1992):

Art. $3^{\circ}$ As disposições desta Lei são aplicáveis, no que couber, àquele que, mesmo não sendo agente público, induza ou concorra para a prática do ato de improbidade ou dele se beneficie sob qualquer forma direta ou indireta.

Art. $5^{\circ}$ Ocorrendo lesão ao patrimônio público por ação ou omissão, dolosa ou culposa, do agente ou de terceiro, dar-se-á o integral ressarcimento do dano.

Art. $6^{\circ}$ No caso de enriquecimento ilícito, perderá o agente público ou terceiro beneficiário os bens ou valores acrescidos ao seu patrimônio.

$\mathrm{Na}$ definição de agente público, observa-se que o legislador adotou um conceito mais amplo para alcançar todos aqueles que, de alguma forma, contribuíram para o prejuízo da coisa pública. Mesmo aqueles que não exercem 
qualquer função pública, mas auxiliaram na execução dos atos de improbidade, estão sujeitos às mesmas penalidades legais.

A doutrinadora Di Pietro (2007) descreve o "agente público" como sendo toda pessoa física que presta serviços ao Estado, atuando na Administração Pública direta ou indireta. $\mathrm{O}$ autor ainda classifica o agente público em: agentes políticos, servidores públicos, militares e particulares em colaboração com o Poder Público.

Em entendimento mais amplo, Araújo (2005, p.243) extrapola esse entendimento, definindo como agente público "todo aquele que, de alguma forma, sob qualquer categoria ou título jurídico, desempenha função ou atribuição considerada pelo Poder Público como a si pertinente".

Cretella Júnior (1970, p.138), em uma doutrina tradicional, define agente público como uma terminologia para designar todo indivíduo que participa de maneira permanente, temporária ou acidental da atividade do Estado, quer editando atos jurídicos ou executando atos de natureza técnica e material.

Mello (2003, p. 226 e 227) define agentes públicos como sujeitos que servem ao Poder Público, ainda quando o façam apenas de forma ocasional ou episodicamente.

\footnotetext{
Quem quer que desempenhe funções estatais, enquanto as exercita, é um agente público. Por isso, a noção abarca tanto o Chefe do poder Executivo (em quaisquer das esferas) como os senadores, deputados e vereadores, os ocupantes de cargos ou empregos públicos da Administração direta dos três Poderes, os servidores das autarquias, das fundações governamentais, das empresas públicas e sociedades de economia mista nas distintas órbitas de governo, os concessionários e permissionários do serviço público, os delegados de função ou ofício público, os requisitados, os contratados sob locação civil de serviços e os gestores de negócios públicos.
}

Em uma subdivisão dessa definição, Mello (2003, p. 229) classifica o agente público em três espécies, sendo: a) agentes políticos, b) servidores estatais e c) particulares em colaboração com o Estado.

Essa subdivisão doutrinária, porém, não é pacífica. Di Pietro (2004, p. 431) classifica o agente público em quatro espécies: a) agentes políticos, b) servidores públicos, c) militares e d) particulares em colaboração com o Poder Público. 


\title{
2.3.1 Agentes políticos
}

Existem vários entendimentos doutrinários no que se refere ao conceito de agentes políticos. Preferindo uma descrição mais ampla, Meirelles (2004, p.222) afirma que:

Agentes políticos constituem, na realidade, categoria própria de agente público. Porém, sem dúvida, no título e seções referidas, a Carta Magna, para fins de tratamento jurídico, coloca-os como se fossem servidores públicos, sem embargo de os ter como agentes políticos, como se verá mais adiante. Todos os cargos vitalícios são ocupados por agentes políticos, porém esses também ocupam cargos em comissão, como os Ministros dos Estados. Normalmente deverão ser regidos pelo regime estatutário, contudo alguns estão obrigatoriamente submetidos a um regime estatutário de natureza peculiar, a exemplo da Magistratura e do Ministério Público.

Em conceituação diversa, Mello (2003, p. 229) adota uma aplicação mais restrita:

\begin{abstract}
Agentes políticos são os titulares dos cargos estruturais à organização política do País, ou seja, ocupantes dos que integram o arcabouço constitucional do Estado, o esquema fundamental do poder. Daí que se constituem nos formadores da vontade superior do Estado. São agentes políticos apenas o Presidente da República, os Governadores, os Prefeitos e respectivos vices, os auxiliares imediatos dos chefes de Executivo, isto é, Ministros e Secretários das diversas Pastas, bem como os senadores, Deputados federais e estaduais e os vereadores.
\end{abstract}

Mello (2003) defende que o vínculo que tais agentes possuem com o Estado não é de natureza profissional, mas de natureza política. Com esse entendimento, defende que deve ser considerado o fato de que os agentes políticos exercem atividade essencialmente política, desempenhadas, predominantemente, pelo Poder Executivo e também pelo Poder Legislativo.

Essa posição é compartilhada por Di Pietro (2004, p. 432) que, ao comparar as conceituações de Meirelles (2004) e Mello (2003), argumenta que "esta última conceituação é a preferível. A ideia de agente político liga-se, indissociavelmente, à de governo e à de função política, a primeira dando ideia de órgão (aspecto subjetivo), e a segunda, de atividade (aspecto objetivo)". 


\subsubsection{Servidores públicos}

No conceito de Di Pietro (2004, p. 433), são considerados servidores públicos as pessoas físicas que prestam serviços ao Estado e às entidades da Administração Pública Indireta, com vínculo empregatício e mediante remuneração paga pelos cofres públicos.

Segundo a autora, os servidores públicos podem ser classificados em: servidores estatutários, empregados públicos e servidores temporários. Os estatutários estão sujeitos ao estatuto do servidor e são ocupantes de cargos públicos. Os empregados públicos são aqueles regidos pela Consolidação das Leis Trabalhistas (CLT) ocupantes de empregos públicos e os servidores temporários, que são os contratados para atender uma necessidade transitória, exercendo função sem vínculo com o cargo ou emprego público.

Mello (2003, p. 230) classifica os servidores públicos como sendo espécies do gênero servidores estatais. A designação "servidores estatais":

[...] abarca todos aqueles que entretêm com o Estado e suas entidades da Administração indireta, independentemente de sua natureza pública ou privada (autarquias, fundações, empresas públicas e sociedades de economia mista), relação de trabalho de natureza profissional e caráter não eventual sob o vínculo de dependência.

Esclarece, ainda, o mencionado doutrinador, que a designação servidores públicos possui um alcance restrito, não sendo adequada para incluir os empregados das instituições de Administração Pública indireta de Direito Privado (estatais). Para Mello (2003), os servidores públicos se diferenciam das pessoas governamentais de Direito Privado.

Contrariando esse ensinamento, Di Pietro (2004) afirma que os empregados públicos da Administração Pública Indireta de Direito Privado devem ser considerados servidores públicos. Para Mello (2003), esses servidores não devem ser considerados assim, pois não estão submetidos ao regime estatutário; portanto, não se adequam a essa denominação. Submetem-se a um regime jurídico próprio, estando sujeitos à Consolidação das Leis Trabalhistas; por isso, não podem ser considerados servidores públicos. 


\title{
2.3.3 Militares
}

Di Pietro (2004) sugere uma classificação específica para os militares, a qual abrange as Polícias Militares e Corpos de Bombeiros dos Estados, Distrito Federal e Territórios, além de todas as pessoas físicas que prestam serviços às Forças Armadas: Marinha, Exército e Aeronáutica.

No entanto, Cunha Júnior (2006, p. 208) prefere denominá-los simplesmente como servidores públicos (estatais):

\begin{abstract}
São servidores estatais sujeitos a regime jurídico especial que devem estabelecer normas sobre ingresso, limites de idade, estabilidade, transferência para a inatividade, direitos, deveres, remuneração, prerrogativas e outras situações especiais consideradas as peculiaridades de suas atividades (CF, art. $42, \S 1^{\circ}$ e $\left.142, \S 3^{\circ}, \mathrm{X}\right)$. Incluem-se nessa espécie os membros das Polícias Militares e Corpos de Bombeiros Militares dos Estados, do Distrito Federal e dos Territórios (CF, art. 42) e os membros das Forças Armadas (CF, art. 142).
\end{abstract}

\subsubsection{Particulares em colaboração com o Poder Público}

Para Cunha Júnior (2006), fazem parte dessa categoria as pessoas físicas que, sem vínculo empregatício, prestam serviços ao Estado, de forma remunerada ou não. Importante observar que, nesses casos, os particulares atuam em nome próprio, cabendo ao Estado somente fiscalizar o desempenho dessas atividades.

A classificação elaborada por Mello (2003) alcança todos os particulares que colaboram com o Poder Público de alguma forma, podendo ser: por delegação, concessão e permissão de serviços públicos. Esse entendimento abrange também: Leiloeiros, tradutores, peritos, assim como os que exercem serviços notariais e de registro. A remuneração se dá pelos próprios usuários e não pelo Estado.

\subsection{5 conselheiro como agente público}

O conselheiro, membro do Conselho de Saúde, seja ele eleito ou designado pelo gestor público, alcança o status de agente público, posto que sua definição abrange todo o indivíduo que exerce, ainda que temporariamente ou mesmo sem remuneração, qualquer função pública, seja por eleição, nomeação, designação, contratação ou qualquer outra forma de investidura ou vínculo com o ente público, 
empresa incorporada ao patrimônio público ou de entidade para cuja criação ou custeio o erário haja concorrido ou concorra com mais de cinquenta por cento do patrimônio ou da receita anual, nos termos dos art. $1^{\circ}$ e $2^{\circ}$ da Lei $n^{\circ} 8.429$, de 1992 (BRASIL, 1992):

\begin{abstract}
Art. $1^{\circ}$ Os atos de improbidade praticados por qualquer agente público, servidor ou não, contra a administração direta, indireta ou fundacional de qualquer dos Poderes da União, dos Estados, do Distrito Federal, dos Municípios, de Território, de empresa incorporada ao patrimônio público ou de entidade para cuja criação ou custeio o erário haja concorrido ou concorra com mais de $50 \%$ (cinquenta por cento) do patrimônio ou da receita anual, serão punidos na forma desta Lei.

Art. $2^{\circ}$ Reputa-se agente público, para os efeitos desta Lei, todo aquele que exerce, ainda que transitoriamente ou sem remuneração, por eleição, nomeação, designação, contratação ou qualquer outra forma de investidura ou vínculo, mandato, cargo, emprego ou função nas entidades mencionadas no artigo anterior.
\end{abstract}

Nesse entendimento Santo (2012, p. 158, grifos nossos) é incisivo ao afirmar a condição do conselheiro, membro do Conselho de Saúde, como agente público, sujeito a todas as normas e regulamentações cabíveis:

Por fim, resta saber se o conselheiro de saúde também é passível de punição quando descumprir com as obrigações legais e regimentais do Conselho de Saúde e as da LC 141/12. O conselheiro é um agente público, ainda que exerça suas atividades de forma gratuita, e todo agente público deve responder perante o Poder Público pelo exercício das atividades que lhe forem conferidas por Lei.

\title{
2.4 Atos de improbidade administrativa
}

O crime de improbidade administrativa abrange não somente os gestores da administração direta e indireta, mas alcança todo agente público, no exercício de sua função, os quais promovam atos que atentem contra os princípios da administração pública, causando enriquecimento ilícito ou prejuízo ao patrimônio público.

A Lei Federal 8.429/1992 (BRASIL, 1992) define os atos de improbidade praticados por qualquer agente público, conforme descrito:

Art. $1^{\circ}$ Os atos de improbidade praticados por qualquer agente público, servidor ou não, contra a administração direta, indireta ou fundacional de qualquer dos Poderes da União, dos Estados, do Distrito Federal, dos Municípios, de Território, de empresa incorporada ao patrimônio 
público ou de entidade para cuja criação ou custeio o erário haja concorrido ou concorra com mais de cinquenta por cento do patrimônio ou da receita anual, serão punidos na forma desta Lei.

Parágrafo único. Estão também sujeitos às penalidades desta Lei os atos de improbidade praticados contra o patrimônio de entidade que receba subvenção, benefício ou incentivo, fiscal ou creditício, de órgão público bem como daquelas para cuja criação ou custeio o erário haja concorrido ou concorra com menos de cinquenta por cento do patrimônio ou da receita anual, limitando-se, nesses casos, a sanção patrimonial à repercussão do ilícito sobre a contribuição dos cofres públicos.

A tipificação dada pela Lei $n^{\circ}$. 8.429/92 (BRASIL, 1992) prevê que, além dos agentes públicos propriamente definidos, também são passivos da prática de atos de improbidade administrativa o particular que, de alguma forma, concorra ou dele se beneficie, conforme previsão do art. $3^{\circ}, 5^{\circ}$ e $6^{\circ}$ da Lei 8.429/95 (BRASIL, 1992):

Art. $3^{\circ}$ As disposições dessa Lei são aplicáveis, no que couber, àquele que, mesmo não sendo agente público, induza ou concorra para a prática do ato de improbidade ou dele se beneficie sob qualquer forma direta ou indireta.

Art. $5^{\circ}$ Ocorrendo lesão ao patrimônio público por ação ou omissão, dolosa ou culposa, do agente ou de terceiro, dar-se-á o integral ressarcimento do dano.

Art. $6^{\circ}$ No caso de enriquecimento ilícito, perderá o agente público ou terceiro beneficiário os bens ou valores acrescidos ao seu patrimônio.

O conceito de ato de improbidade administrativa não é claramente definido pela doutrina, como afirma Fazzio Júnior (2000, p. 45). Por isso, torna-se um tema complexo, de difícil conceituação. O autor apresenta uma simples noção:

Não adianta palmilhar a busca de um conceito preciso nessa matéria. Também não é oportuno importá-lo do regramento legal, porque este é extremamente detalhado e, por isso, capaz de produzir sensíveis confusões exegéticas... a probidade é espécie do gênero moralidade administrativa.

Medauar (1999, p. 38) vincula o conceito de probidade ao princípio da moralidade administrativa, como referência de conduta:

A probidade, que há de caracterizar a conduta e os atos das autoridades e agentes públicos, aparecendo como dever, decorre do princípio da moralidade administrativa. Na linguagem comum, probidade equivale a honestidade, honradez, integridade de caráter, retidão. A improbidade administrativa tem um sentido forte de conduta que lese o erário público, que importe em enriquecimento ilícito ou proveito próprio ou de outrem no exercício do mandato, cargo, função, emprego público. 
Em um posicionamento convergente, Gomes Júnior (2004, p. 86) comenta acerca da aplicação da moralidade administrativa:

Outra questão relevante é delimitar o que é o Princípio da Moralidade Administrativa. Segundo os administrativistas, teria sido Hauriou o primeiro jurista a abordar o tema da Moralidade Administrativa sob a ótica atual. Em suas palavras, seria um princípio que dependeria da análise da conduta em decorrência de uma distinção entre o bem e o mal. Na administração haveria sempre uma diferenciação, além daquela envolvendo os conceitos de justo e injusto, do honrado e desonrado, do que seria conveniente do inconveniente. Poder Público estaria atuando por uma noção de moral jurídica, especialmente quando em análise de atos tidos como praticados com desvio e poder.

Impossível ignorar que a noção de "moralidade administrativa" é um conceito vago. Não restam dúvidas de que a concepção de justo e injusto varia de indivíduo para indivíduo, sendo comumente aceito que o ato moral está dentro de um conceito de "justo", ao contrário daquele que possui a pecha de imoral, apesar das dificuldades de se conceituarem ou de se delimitarem tais situações pela evidente carga de subjetividade em tal análise.

Moraes (1999, p. 65) traça um paralelo entre o princípio da legalidade dos atos do gestor público e o princípio da moralidade administrativa:

Pelo princípio da moralidade administrativa, não bastará ao administrador o estrito cumprimento da estrita legalidade, devendo ele, no exercício de sua função pública, respeitar os princípios éticos de razoabilidade e justiça, pois a moralidade constitui, a partir da Constituição de 1988, pressuposto de validade de todo ato da administração pública... O princípio da moralidade está intimamente ligado com a ideia de probidade, dever inerente do administrador público.

Na lição de Horta (2004, p. 15) é mencionado o desvio de conduta do agente público:

[...] a corrupção é manifestação maligna, que nega a moralidade administrativa. $\mathrm{Na}$ linguagem vernácula, a improbidade, designa a desonestidade, a maldade, a perversidade; equivale ao ímprobo, que conduz ao improbus administrador, caracterizando, no serviço público, o administrador desonesto.

Gomes Júnior (2004, p. 16, grifos nossos) ressalta que a moral administrativa é o princípio pelo qual o administrador deve pautar suas ações, seguindo a noção de moral, contudo buscando o interesse público, observando sempre os parâmetros legais: 
Numa primeira aproximação, improbidade administrativa é o designativo técnico para a chamada corrupção administrativa, que, sob diversas formas, promove o desvirtuamento da Administração Pública e afronta os princípios nucleares da ordem jurídica (Estado de Direito, Democrático e republicano), revelando-se pela obtenção de vantagens patrimoniais indevidas a expensas do erário, pelo exercício nocivo das funções e empregos públicos, pelo "tráfico de influência" nas esferas da Administração Pública e pelo favorecimento de poucos em detrimento dos interesses da sociedade, mediante a concessão de obséquios e privilégios ilícitos.).

A Constituição Federal (BRASIL, 1988) estabelece no art. 37, §4 as penas para os atos de improbidade, sem prejuízo da ação penal cabível.

Art. 37. A administração pública direta e indireta de qualquer dos Poderes da União, dos Estados, do Distrito Federal e dos Municípios obedecerá aos princípios de legalidade, impessoalidade, moralidade, publicidade e eficiência e, também, ao seguinte:

[...]

$\S 4^{\circ}$ Os atos de improbidade administrativa importarão a suspensão dos direitos políticos, a perda da função pública, a indisponibilidade dos bens e o ressarcimento ao erário, na forma e gradação previstas em Lei, sem prejuízo da ação penal cabível.

A Lei 8.429/1992 (BRASIL, 1992), que define os atos de improbidade administrativa, estabelece sanções a serem aplicadas, sem prejuízo de outras penalidades na esfera cível, penal ou administrativa.

Art. 12. Independentemente das sanções penais, civis e administrativas previstas na legislação específica, está o responsável pelo ato de improbidade sujeito às seguintes cominações, que podem ser aplicadas isolada ou cumulativamente, de acordo com a gravidade do fato:

I - na hipótese do artigo $9^{\circ}$, perda dos bens ou valores acrescidos ilicitamente ao patrimônio, ressarcimento integral do dano, quando houver, perda da função pública, suspensão dos direitos políticos de 8 (oito) a 10 (dez) anos, pagamento de multa civil de até 3 (três) vezes o valor do acréscimo patrimonial e proibição de contratar com o Poder Público ou receber benefícios ou incentivos fiscais ou creditícios, direta ou indiretamente, ainda que por intermédio de pessoa jurídica da qual seja sócio majoritário, pelo prazo de 10 (dez) anos;

II - na hipótese do artigo 10, ressarcimento integral do dano, perda dos bens ou valores acrescidos ilicitamente ao patrimônio, se concorrer esta circunstância, perda da função pública, suspensão dos direitos políticos de 5 (cinco) a 8 (oito) anos, pagamento de multa civil de até 2 (duas) vezes o valor do dano e proibição de contratar com o Poder Público ou receber benefícios ou incentivos fiscais ou creditícios, direta ou indiretamente, ainda que por intermédio de pessoa jurídica da qual seja sócio majoritário, pelo prazo de 5 (cinco) anos;

III - na hipótese do artigo 11, ressarcimento integral do dano, se houver, perda da função pública, suspensão dos direitos políticos de 3 (três) a 5 (cinco) anos, pagamento de multa civil de até 100 (cem) vezes o valor da remuneração percebida pelo agente e proibição de contratar com o Poder Público ou receber benefícios ou incentivos fiscais ou creditícios, direta ou indiretamente, ainda que por intermédio de pessoa jurídica da qual seja sócio majoritário, pelo prazo de 3 (três) anos. 
3 PROPOSIÇÃO 



\section{PROPOSIÇÃO}

\subsection{Objetivo geral}

Este estudo tem por objetivo analisar o discurso dos membros do Conselho de Saúde quanto a sua percepção sobre o desempenho das suas funções de fiscalização e controle do sistema de saúde nos termos da legislação vigente.

\subsection{Objetivos específicos}

3.2.1 Analisar a percepção dos membros do Conselho Municipal de Saúde quanto a sua contribuição para a elaboração das políticas de saúde em nível local.

3.2.2 Analisar a percepção dos membros do Conselho de Saúde quanto ao nível de informação sobre o Controle Social e o poder deliberativo desse Conselho.

3.2.3 Analisar a percepção dos membros do Conselho de Saúde quanto a necessidade de acompanhamento do financiamento do setor de saúde e a respectiva prestação de contas.

3.2.4 Analisar a percepção dos membros do Conselho de Saúde quanto ao seu papel como agente público na função de Conselheiro. 

4 MATERIAL e Métodos 



\section{MATERIAL E MÉTODOS}

\subsection{Características do cenário de pesquisa}

O estudo foi realizado no município de Bauru, no estado de São Paulo, região centro-oeste, distante da capital $345 \mathrm{~km}$, população de 366.992 habitantes. O Índice de Desenvolvimento Humano Municipal (IDH-M) de Bauru é de 0,801, sendo o $20^{\circ}$ maior de todo o estado de São Paulo e o $37^{\circ}$ de todo o Brasil (entre 5.565). O Produto Interno Bruto (PIB) de Bauru é o $18^{\circ}$ maior do estado de São Paulo e o $68^{\circ}$ de todo o país, em um total de R\$ 6.795.517 mil (IBGE, 2015).

A prestação de serviços e o comércio são as maiores fontes geradoras de riqueza do município, com destaque do setor educacional universitário, o qual possui cinco universidades (Uninove , Universidade de São Paulo - USP, Universidade do Sagrado Coração - USC, Universidade Estadual Paulista - Unesp, Universidade Paulista - UNIP), somadas a outras cinco faculdades (Faculdade de Tecnologia de Bauru - Fatec, Faculdade IESB Preve, Faculdade de Direito de Bauru - ITE, Faculdades Anhanguera de Bauru e Faculdades Integradas de Bauru - FIB). (BAURU, 2015).

A área de pesquisa possui 17 Unidades Básicas de Saúde, 6 Unidades de Saúde da Família e oito Unidades de Pronto Atendimento. O município também abriga centros de pesquisas científicas de reconhecimento internacional, com foco no atendimento de anomalias, como o Hospital de Reabilitação de Anomalias Craniofaciais - USP (Centrinho), o Hospital Lauro de Souza Lima e o Instituto Brannemark (BAURU, 2015). 


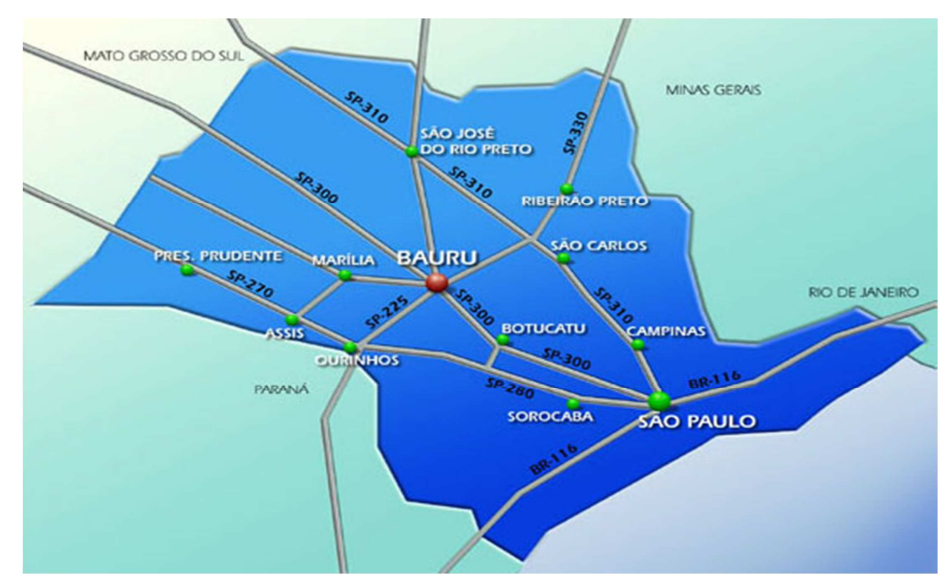

Figura 1 - Localização do município de Bauru.

Fonte: <http://www2.fc.unesp.br/ermac.bauru/chegar.php>. Acesso em 15/11/2015.

\subsection{Delineamento do estudo}

O presente estudo foi realizado usando-se o método de análise transversal, descritivo, qualitativo, baseado na análise do discurso do sujeito e realizado por meio de pesquisa com roteiro semiestruturado.

\subsection{Participantes da pesquisa}

Os conselheiros participantes desta pesquisa fazem parte do Conselho Municipal de Saúde de Bauru, criado em 7 de maio de 2001, por intermédio da Lei Municipal 4.669/2001:

Art. $5^{\circ}$ - Fica criado o Conselho Municipal de Saúde, em caráter permanente, como instância deliberativa do Sistema Único de Saúde, no âmbito municipal, sem prejuízo das funções do Poder Legislativo, a ele competindo:

I - supervisionar o funcionamento e gerenciamento do Fundo Municipal de Saúde;

II - aprovar, por deliberação, no prazo de 60 (sessenta) dias o Plano Municipal de Saúde, podendo emendá-lo, respeitadas as limitações orçamentárias. Caso o Conselho não delibere no prazo fixado, considera-se o Plano aprovado tacitamente;

III - fiscalizar a execução do Plano Municipal de Saúde, podendo para isso requerer informações, relatórios, cronograma e outros elementos necessários, que serão atendidos na forma do inciso $V$, do artigo $3^{\circ}$ desta Lei; 
IV - examinar as propostas encaminhadas pela Secretaria Municipal de Saúde, modificadas no Plano Municipal de Saúde;

$\mathrm{V}$ - propor medidas para o aperfeiçoamento e execução do Plano Municipal de Saúde;

VI - controlar, mensalmente, a receita e a despesa do Fundo Municipal de Saúde;

VII - comunicar, de pronto, ao Prefeito e à Câmara Municipal, as irregularidades na execução do Plano Municipal de Saúde ou no gerenciamento do Fundo Municipal de Saúde;

VIII - comunicar ao Ministério Público suas deliberações não atendidas pelo Poder

Público no prazo estipulado;

IX - opinar sobre política de recursos humanos, materiais e investimentos a serem efetuados no âmbito da Saúde;

$X$ - discutir os problemas de saúde suscitados pela população e propor medidas para resolvê-los ou atenuá-los;

XI - estimular e facilitar a participação da população na discussão e elaboração do Plano Municipal de Saúde.

\section{A formação do Conselho respeitou a composição paritária entre os usuários}

e os demais segmentos representados, totalizando 28 conselheiros:

Art. $6^{\circ}$ - Integram o Conselho Municipal de Saúde:

I - Do Serviço Público:

a) dois representantes da Secretaria Municipal de Saúde;

b) um representante da Secretaria Municipal de Meio Ambiente;

c) um representante da Secretaria Municipal da Educação;

d) um representante local da Secretaria Estadual de Saúde.

II - Dos Profissionais de Saúde e Centros de Formação de Recursos Humanos para a Saúde:

a) um representante da Associação Paulista de Medicina ou do Conselho Regional de Medicina ou do Sindicato dos médicos;

b) dois representantes dos demais profissionais de nível universitário da área de saúde, indicados pelos Conselhos, Delegacias ou Associações Profissionais do Município;

c) um representante das Instituições de Ensino de nível superior e Pesquisa;

d) dois representantes das Entidades Prestadoras de Serviços na Área de Saúde, eleito entre seus pares;

e) três representantes dos trabalhadores do setor Saúde, indicados pelos respectivos Sindicatos.

III - Dos Usuários do Sistema Municipal de Saúde:

a) seis representantes do conjunto das Associações de Moradores;

b) seis representantes do conjunto dos Sindicatos dos Trabalhadores com Sede ou Delegacia Sindical no Município;

c) um representante do conjunto das Associações dos Usuários de Serviços de Saúde;

d) um representante da Associação dos Aposentados.

Atendendo ao determinado pela legislação pertinente, o Conselho Municipal de Bauru constituiu regimento próprio definindo as normas de funcionamento, inclusive alterando o número de conselheiros para 26. 
Para definição dos participantes da pesquisa, dentro do universo de estudo, o pesquisador optou por sortear $75 \%$ (setenta e cinco por cento) dos membros do Conselho de Saúde, pretendendo atingir o ponto de saturação das questões propostas. Foram divididos em dois grupos, um grupo dos representantes dos usuários e outro grupo formado pelas demais categorias. As entrevistas foram realizadas após a aprovação do Comitê de Ética em Pesquisa da Faculdade de Odontologia de Bauru da Universidade de São Paulo.

Foram consideradas perdas os participantes que manifestaram recusas ou não foram localizados, totalizando 4 participantes.

\subsection{Coleta de dados}

Foram realizadas entrevistas individuais com roteiro semiestruturado, permitindo-se ao participante uma resposta abrangente sobre o tema em questão.

As entrevistas foram previamente agendadas em local e horário estabelecidos pelos participantes por meio de gravação de áudio. O equipamento usado foi um iPhone 6 da Apple®.

A pesquisa foi realizada nos meses de outubro e novembro de 2015 . Os pesquisados, sem exceção, foram receptivos, demonstrando grande interesse pelo tema.

O uso de roteiro semiestruturado permite a realização de entrevista flexível e espontânea. Nesse tipo de entrevista, mesmo havendo um roteiro predefinido, o participante tem a liberdade de discorrer sobre outros temas que considera relevante.

\subsection{Análise dos dados coletados}

Foram feitas transcrições literais das entrevistas gravadas a fim de possibilitar a análise do discurso dos sujeitos. Cada entrevistado foi identificado com uma letra, sendo "U" para usuários (10 participantes), "G" para gestores (5 participantes) e "T" para trabalhadores (5 participantes), de modo a preservar a confidencialidade das informações. 
O objetivo do emprego dessa metodologia é a identificação de padrões simbólicos, socialização, valores, concepção e práticas empregadas pelo universo pesquisado, visando compreender a percepção do participante da pesquisa em relação às suas atribuições e responsabilidades enquanto membro do Conselho de Saúde.

A pesquisa teve seu limite quando as respostas apresentadas foram alcançando o "ponto de saturação", tornando-se perceptiva uma ideia central discursiva repetidamente.

Com fulcro na teoria da Representação Social, essa técnica consiste em analisar o depoimento verbal coletado em roteiros abertos ou semiestruturados, extraindo-se o consenso, chamado de "Ideias Centrais" e as suas correspondentes "Expressões Chave".

As Expressões Chave $(\mathrm{ECH})$ são trechos dos depoimentos pesquisados destacados pelo pesquisador que apresentam a essência do conteúdo do discurso ou a teoria subjacente. A Ideia Central (IC) é o termo usado para identificar o consenso presente nas respostas analisadas.

No conjunto de análise dos depoimentos, podem ser percebidos expressões ideológicas embutidas no discurso do autor, como se fosse uma afirmação, chamada de Ancoragem (AC).

\subsection{Procedimento ético}

Antes do início da pesquisa foi apresentado ao participante o TERMO DE CONSENTIMENTO LIVRE E ESCLARECIDO, cuja explicação, em seus detalhes, foi dada pelo pesquisador, dirimindo qualquer dúvida quanto ao procedimento.

Todos os procedimentos previstos no item VII da Resolução n 466/12 do Conselho Nacional de Saúde do Ministério da foram respeitados.

O anonimato do participante da pesquisa foi garantido; o pesquisador procurou deixar bem esclarecido que todas as informações individuais prestadas seriam confidenciais e guardadas por força de sigilo profissional nos termos dos artigos 7, 33 e 54, V, da Lei $n^{\circ} 8.906$, de 4 de julho de 1994, combinados com os artigos 25 a 27 do Código de Ética e Disciplina da Ordem dos Advogados do 
Brasil, assegurando que a posterior publicação dos resultados desse trabalho não permitirá a identificação dos participantes.

Esta pesquisa foi aprovada pelo Comitê de Ética em Pesquisa - CEP- da Faculdade de Odontologia de Bauru - CAEE 48748615.5.0000.5417, parecer número 1.235 .563 de 2015. 


\section{RESULTADOS}





\section{RESULTADOS}

A análise minuciosa das entrevistas realizadas possibilitou a identificação de algumas ideias centrais: a falta de preparo e a necessidade de capacitação do conselheiro, o Conselho de Saúde como palanque político, a falta de empenho do conselheiro, a falta de representatividade do usuário, a falta de conhecimento do SUS e a fiscalização ineficiente das prestações de conta.

\subsection{Preparo dos conselheiros}

Dentre as funções dos Conselhos de Saúde está a responsabilidade por conhecer, analisar, julgar, cobrar e divulgar os programas de saúde. Considerando a complexidade que envolve o desempenho dessa função é necessária uma qualificação técnica e uma estrutura compatível com a tarefa.

O estudo realizado junto ao Conselho Municipal de Saúde do município de Bauru demonstrou a percepção da falta de capacitação dos conselheiros para o exercício de suas funções, conforme relato:

... Então, a nossa dificuldade hoje é ter conselheiro realmente capacitado para ser conselheiro. Tem muitos de boa vontade, mas nem todos têm conhecimento para isso... o conselheiro deveria ser assim, porque ele não tem noção do que é ser um conselheiro ${ }^{U 2}$

Porque eu observo assim, que também o conselheiro, ele tem que ter conhecimento na hora daquele assunto, porque, às vezes a gente percebe que tem pessoas que ela participa, mas com um desconhecimento daquilo que acontece. Ela participa, ela fala, às vezes até tumultua a reunião, mas porque ela não tem conhecimento daquilo ou preparo de como é realizado aquilo... que às vezes a pessoa está ali, mas ela está despreparada realmente para aquilo. ${ }^{\top}$

... porque eu acho que falta um pouco de conhecimento neste sentido, de como fiscalizar, o que fiscalizar... Eu penso que falta um entendimento maior. Acho que eles não fiscalizam por falta de conhecimento. ${ }^{\text {G }}$ 
Eu acho que precisaria haver uma formação, orientação aos conselheiros para que eles realmente entendam o papel deles no Conselho, quais são suas prerrogativas, até onde eles podem ir. O que se observa é que a maioria dos conselheiros não entende, não se aprofunda muito nos assuntos, não procura entender o porquê das coisas. O ideal é, lógico, que cada um se debruçasse sobre os documentos antes de chegar na reunião, mas a maioria das pessoas não tem preparo para analisar este tipo de documento, balanços ou propostas para poder chegar na reunião com uma opinião formada. ${ }^{T 4}$

Essa situação, contudo, não é exclusiva do município de Bauru, conforme Martins et al. (2013) destacam em trabalho de pesquisa, enfatizando que os representantes de todos os segmentos entrevistados não conhecem suficientemente o papel tanto do conselho quanto do conselheiro de saúde. A maioria dos conselheiros de saúde não recebeu capacitação para exercer o cargo.

Essa realidade também é verificada por Oliveira (2011), na pesquisa realizada em Campo Grande/MS, a qual destaca a legitimidade, representatividade e qualificação dos conselheiros. Descreve também que os Conselhos criados há mais tempo têm maior tendência a pausas prolongadas, o que parece apontar a presença de conselheiros despreparados e despolitizados concluindo que a representatividade de conselheiros é fraca.

Labra e Figueiredo (2002) abordam o tema relativo ao desempenho dos Conselhos de Saúde pelo viés do Controle Social, e os resultados obtidos aproximam-se dos resultados da presente pesquisa, ou seja, em geral não é percebido o Controle Social como uma realidade na prática dos Conselhos de Saúde.

Essa falta de preparo e capacitação não se justifica, pois existe previsão legal que obriga o gestor público a disponibilizar ao Conselho de Saúde programa de educação continuada a fim de capacitar o conselheiro para o desempenho de suas funções, conforme determina o artigo 44 da LC 141/12 (BRASIL, 2012):

A falta de implantação desses programas de educação continuada para a capacitação dos conselheiros já ensejaria motivo de rejeição das contas do Poder Executivo. 


\subsection{O Conselho de Saúde como palanque político}

No entendimento de Van Stralen et al. (2006), os Conselhos de Saúde fazem parte de um cenário que busca novas formas de participação sociopolítica, anteriormente arraigadas em política partidária. Esse novo cenário social se dedica a criar instituições democráticas que promovam a inclusão política social. Trata-se de uma inovação institucional que surgiu em um momento de transição social em que a sociedade passou a rejeitar o modelo clientelístico. O novo padrão almeja por participações sociais desenhadas a partir das necessidades da população e da participação direta dos cidadãos no processo de tomada de decisões.

O objetivo de alguns conselheiros em usar o Conselho de Saúde como palanque político partidário, usando a visibilidade da função meramente para a promoção pessoal, ficou nítido na percepção de um dos conselheiros pesquisados, ao mencionar:

Os conselheiros, mesmo, que representa a grande maioria da população, é até triste eu falar isso, mas o que eu faço uma leitura existe um interesse muito político, então eu quero ir lá, mostrar que eu sei brigar, que eu quero fazer, porque eu tenho um interesse futuro, talvez, em ser conhecido, em alguém votar em mim, sei lá. Porque, às vezes, a questão política interfere muito... Infelizmente, as pessoas misturam ser conselheiro com ser político, e aí a gente não sai daquele lugar ${ }^{T 2}$

\subsection{Empenho do conselheiro}

Outro dado que mereceu destaque nas falas selecionadas da entrevista foi o fato de que os representantes do gestor público possuíam uma estrutura administrativa que pendia a seu favor, ao passo que os representantes dos demais segmentos, em especial dos usuários, além de não ter flexibilidade de suas atividades, tinham que custear suas despesas..

Outro dado observado foi a falta de empenho e proatividade dos membros do Conselho, em função da ausência e falta de pontualidade nas reuniões.

... mas também a questão da disponibilidade, porque a maior parte das pessoas trabalha. Isso é um limitante também, é um fator limitante. ${ }^{G 1}$ 
Por exemplo, é só uma coisa que é irritante, tem uma chamada às $19 \mathrm{~h}$, não tem ninguém; tem uma chamada às 19h30, não tem ninguém. Quinze para as 20h, o pessoal começa a chegar, nós fomos convocados para as $19 \mathrm{~h}$.

Então, existe essa... e é sempre aquelas pessoas que são representantes da Casa do Conselho que chegam às $21 \mathrm{~h}$. Então, essas coisas são muito ruins, porque a gente trabalha $o$ dia inteiro, o pessoal da Secretaria da Saúde também, a gente vê que eles ficam lá direto. O pessoal que vem mesmo, que deveria estar representando, que era quem mais deveria estar ali, eu não sinto muito essa... sabe? Hoje eu vejo que o Conselho de Saúde ele é feito pelos funcionários da Secretaria da Saúde e as instituições que prestam serviço, porque os conselheiros, mesmo, muito pouco. Tem conselheiro lá que começou no começo do ano e nunca mais eu vi". T2

Gostaria que os membros eleitos fossem mais atuantes e participativos, comprometidos com o cargo que os mesmos se disponibilizaram a aceitar, porque eu só sou conselheira porque eu me disponibilizei a estar lá. E se eu me disponibilizei a estar lá, por que eu não estou? Na verdade, não muda em nada a minha vida profissional eu estando lá ou não estando, mas, com certeza, se eu me disponibilizei estar e não estou, com certeza eu vou fazer falta na hora das votações. Porque às vezes a gente fica esperando dar quórum para que a gente comece as reuniões. Então, se você não quer ser um conselheiro, não fique lutando para ser, então... T3

\subsection{Representatividade do usuário}

Em pesquisa realizada em alguns municípios do estado do Mato Grasso, Van Stralen et al. (2006) enfocam os conselheiros que representam os usuários, especialmente em relação à análise do perfil socioeconômico e cultural, discutindo os recursos e as desigualdades entre os segmentos. Tal estudo enfatizou a falta de capacitação técnica e política dos conselheiros para ocupar espaços de negociação; entretanto, ressaltou que os Conselhos são espaços de aprendizagem de cidadania e de desenvolvimento de capital social.

Em que pese a determinação legal de que o Conselho de Saúde deva ser composto por cinquenta por cento de representantes dos usuários, essa cota, às vezes, é preenchida por entidades organizadas por seus participantes. Isso ficou claro a partir do depoimento de um dos conselheiros pesquisados: 
Então, eu entendo que teria que se mudar, melhorar, a representatividade de usuários colocando no Conselho conselheiros e pessoas indicadas por essas entidades que realmente representassem o interesse do usuário final. ${ }^{G 1}$

Em pesquisa realizada no interior de Pernambuco, Vasques et al. (2005) relatam um cenário semelhante, pois há algumas instituições organizadas com representantes atuando por meio da cota de usuários, o que mascara e deturpa o verdadeiro objetivo do Controle Social.

Devido à predominância da representação de setores com maior capacidade de organização, há uma tendência de a participação nos Conselhos se elitizar, como sugerem Van Stralen et al. (2006). Em sua pesquisa houve destaque à variedade de entidades que representam os usuários, como as associações comunitárias, sindicatos, entidades religiosas e representantes de gênero e etnia.

\subsection{Entendimento sobre o funcionamento do SUS}

Considerando a falta de conhecimento do SUS, no entendimento de Van Stralen et al. (2006) não é surpresa que as principais necessidades apontadas pelos informantes, em sua pesquisa, digam respeito a carências do sistema de saúde, tais como acesso a medicamentos e consultas especializadas.

Nessa perspectiva, a possibilidade de os Conselhos contribuírem para a reestruturação e melhoria dos serviços de saúde sem o conhecimento do SUS é meramente hipotética.

A estruturação das discussões e deliberações dos Conselhos de Saúde depende essencialmente do conhecimento do mecanismo de atuação do SUS. Não é possível prosseguir em um processo de tomada de decisão sem entender como o sistema funciona.

Então, os conselheiros tinham que ter ideia do que realmente é o SUS, o que ele representa, quer dizer, entender o conjunto, entender a finalidade, que é buscar atender a todos. ${ }^{\mathrm{G} 1}$

Precisava realmente que eles conhecessem a fundo a política de saúde hoje implantada pelo SUS, que é uma política que traz benefício para a população, apesar de parecer tão ruim, mas ela é... e eu sou uma defensora do SUS, meu salário vem 
do SUS, eu vejo o quanto que o SUS beneficia os pacientes que a gente atende diariamente, então eu acho que a gente precisa conhecer. ${ }^{T 2}$

Eu acho que ele deveria conhecer mais a política do SUS, entender como funciona o sistema, como funciona o Sistema de Saúde, entender os mecanismos que o Conselho pode intervir nessa política. Eu acho que deveria haver um aprofundamento maior do conselheiro para que ele consiga entender mais o papel dele. ${ }^{\text {T4 }}$

Os relatos de falta de conhecimento da estrutura do SUS por parte de alguns conselheiros constituem um dado preocupante, pois demonstra o despreparo para o exercício das funções relativas ao cargo.

Em que pese a complexidade técnica nas mais diversas áreas de conhecimento que são exigidas para o desempenho das funções do Conselho de Saúde, entender o funcionamento do SUS é fundamental para a atuação do conselheiro.

\subsection{Fiscalização das prestações de conta}

Martins et al. (2013) ressaltam o processo de descentralização da saúde, no qual a criação dos Conselhos de Saúde se deu como uma exigência para o repasse de recursos da esfera federal para as esferas estaduais e municipais. Nesse contexto, criaram-se muitos Conselhos simplesmente para viabilizar o recebimento dos recursos, e esses se caracterizam majoritariamente pela manipulação de sua composição, ingerência dos gestores e atuação inexpressiva no sentido de aprovar documentos para repasse de recursos.

É importante ressaltar o posicionamento de Van Stralen et al. (2006) quanto à efetividade da deliberação e a aprovação das contas do executivo, quando o presidente do Conselho de Saúde é o secretário de saúde. Os autores salientam que a permanência do secretário de Saúde como presidente do Conselho indica uma possível restrição da autonomia do Conselho, podendo caracterizar-se uma manipulação do colegiado. 
O legislador pátrio teve a preocupação em discriminar recursos mínimos para o financiamento público do setor saúde em todas as esferas do governo, além de especificar como devem ser utilizadas as verbas.

Todo esse empenho em instituir um mecanismo da democracia participativa e Controle Social seria inócuo sem a efetiva fiscalização das aplicações das verbas por meio das prestações de conta.

Nesse contexto, a população fica refém de uma gestão sem referência administrativa.

Às vezes, falando enquanto funcionário da Secretaria, eu tenho a sensação de que as fiscalizações de contas pouco ocorrem ou não ocorrem. G3

Van Stralen et al. (2006) também mencionam que a instituição dos Conselhos de Saúde como órgãos de Controle Social e gestão participativa são fruto da mobilização de profissionais de saúde e de setores da sociedade civil; contudo, na maioria dos municípios, sua implantação resultou de uma política de indução do Ministério da Saúde, condicionando o repasse de recursos federais à criação do Conselho Municipal de Saúde. Esse processo resultou em Conselhos muito heterogêneos, por vezes cartoriais, sem uma fiscalização eficiente dos gestores do SUS. Van Stralen et al. (2006) observam que as deliberações pareciam pautar-se mais por um discurso em defesa dos princípios do SUS do que por considerações técnicas ou orçamentárias, como sugere o fato de que apenas um informante soube participar o percentual dos gastos municipais aplicados à saúde e nenhum sabia o percentual dos gastos com atenção básica.

Isso reforça o fato de a capacitação dos conselheiros de saúde ser primordial para o exercício de suas funções.

\subsection{A necessidade de capacitação do conselheiro}

Outro dado verificado na pesquisa junto aos conselheiros foi a conscientização da necessidade de capacitação, como importante ferramenta para o desempenho de suas funções: 
Uma capacitação nesse sentido penso que poderia ajudar... uma necessidade, com os municípios da região, de participação, de capacitação para uma participação mais efetiva, até para que eles entendam qual é o verdadeiro papel deles enquanto conselheiros de saúde. ${ }^{G 3}$

A capacitação ajudaria muito. Até nisso que eu estou falando, do despreparo da pessoa. É bem-vinda a capacitação. ${ }^{T 1}$

Então, sinto que uma capacitação é fundamental. Acho que deveria ser assim... deveria ser como se fosse uma condição para você continuar como conselheiro.

Capacitação, com certeza. Eu acho que deveria ter mais treinamento para que as pessoas, na verdade, soubessem as atribuições que lhe competem e desempenhá-las com mais segurança, tranquilidade.

Não seria uma, seriam várias capacitações que deveria ser feito mesmo, periodicamente, não só falar, mas teria que ter uma capacitação periódica e mais objetiva e qualificada para que o conselheiro realmente entenda, primeiro, que ele entenda seu papel, para que ele possa levar esse entendimento do que é função dele para a sociedade para que a sociedade conheça e entenda o que é um Conselho. ${ }^{T 5}$

Seria muito bom uma capacitação. ${ }^{44}$

A necessidade de capacitação foi mencionada pela grande maioria dos pesquisados como essencial para o desempenho da função de conselheiro. Foi sugerido até mesmo um programa de educação continuada.

Os entrevistados afirmaram que a capacitação oferecida foi há tanto tempo que a maioria dos atuais conselheiros não chegaram a participar.

Esse dado reforça a falta de preparo dos conselheiros, pois a LC 141/12 determina ao gestor a implantação de um programa de capacitação permanente.

O fato de não existir um programa de educação continuada ensejaria em reprovação das contas da Secretaria Municipal de Saúde. 



\section{DISCUSSÃO}

\subsection{Controle Social}

O Controle Social pode ser exercido individualmente pelo cidadão, por meio da ação popular ou de forma coletiva, representados por uma instituição, através da ação civil pública.

É de suma importância diferenciar a peculiaridade de cada instrumento processual, a fim de entender e definir suas aplicações e suas implicações.

A ação popular, como instrumento processual, permite ao cidadão exercer o Controle Social individualmente, provocando o poder judiciário quanto às decisões e atos administrativos que possam ter trazido prejuízos à coisa pública.

Como objeto do pedido, busca a anulação, prevenção ou reparação do dano resultante de decisões que lesam o patrimônio histórico, cultural ou do meio ambiente, assim como o erário público ou de instituições que tenham a participação do Estado. Também pode ser proposta preventivamente, impedindo a ocorrência de atos que possam trazer prejuízo ao bem tutelado.

A ação popular, em suma, é um instrumento jurídico de cunho social que permite a fiscalização e intervenção direta do cidadão na Administração Pública, conforme mencionada por Reis (2014). Ao cidadão é declinada a possibilidade de intervir no rumo da Administração Pública para fins corretivo-reparatórios, desde que verificada a hipótese de violação aos seus princípios vetores, legalidade, moralidade, entre outros.

Compartilhando esse entendimento, Meirelles (1995) destaca a ação popular como instrumento democrático, posto à disposição de qualquer cidadão para obter a invalidação de atos ou contratos administrativos - ou a este equiparado.

Em concordância com a doutrina predominante, estão os ensinamentos de Dinamarco (2001), para quem a ação popular é um instituto processual civil colocado à disposição de qualquer cidadão como garantia político-constitucional e com o objetivo de defender os interesses da coletividade, mediante a provocação do poder judiciário, impedindo atos lesivos do patrimônio público, da moralidade administrativa, do meio ambiente e do patrimônio histórico e cultural. 
É válido ressaltar que o objeto tutelado pela ação não se limita ao ato ou à omissão da administração pública (que causa prejuízo financeiro), mas alcança decisões ilegais ou afronta o princípio da moralidade. A lesão ao patrimônio público não é apenas financeira ou econômica, admitindo-se a lesão não econômica, moral, cívica ou cultural, na medida em que o texto constitucional afirma que a ação popular visa anular também ato lesivo à moralidade administrativa, ao meio ambiente e ao patrimônio histórico e cultural (SIQUEIRA JR., 2012, p. 549-550).

Esse conceito deve ser aceito com cautela, pois, caso o poder judiciário intervenha na administração pública com fulcro apenas na imoralidade, poderia promover uma ingerência. "Sem que se alegue vício de legalidade, suscetível de ensejar a anulação do ato, não se configurará a primeira das condições da ação - a possibilidade jurídica do pedido" (MEDINA, 2006, p. 125-126).

Nesse mesmo compasso, a ação civil pública é uma ferramenta jurídica apta para o exercício do Controle Social promovido por instituições organizadas, pois busca reavaliar as decisões e os atos administrativos proferidos pela administração pública. Esse instrumento processual constitucional atribui a legitimidade ativa somente às instituições organizadas, públicas ou privadas, para atuar no polo ativo da lide, assim como autoriza o Ministério Público (BRASIL, 1988), a fim de coibir os atos de improbidade administrativa danosos aos interesses difusos, coletivos e individuais homogêneos da sociedade.

A ação civil pública inovou como instrumento jurídico de Controle Social e institucional ao buscar a cessação ou a prevenção de atos que causem danos ao consumidor ou ao patrimônio público, com destinação específica, não podendo ser proposta em defesa de direitos particulares ou disponíveis, conforme regulamentação pela Lei n. 7.347/85 (BRASIL, 1985).

O objeto da ação civil pública é a defesa dos direitos constitucionais e infraconstitucionais, atacados por ato ilegal ou lesivo à coletividade, tendo como resultado dano ao meio ambiente, ao consumidor, a bens e direitos de valor artístico.

Nesse sentido, enfatiza Aguiar JR. (1995, p. 23) que os pedidos propostos em sede de uma ação civil pública devem estar em concordância com o artigo $3^{\circ}$ da Lei 7.347/85, quanto à obrigação de fazer ou de não fazer, assim como a condenação em dinheiro.

Nesses termos, a ação civil pública pode ser proposta pelo Ministério Público, pela União, pelos Estados, Municípios, Distrito Federal, assim como as 
empresas públicas, fundações, sociedades de economia mista e associações. No caso de desistência infundada do processo, o Ministério Público ou qualquer outro legitimado poderá prosseguir no feito, excluindo a atuação individual do cidadão.

É importante destacar que a legislação não limita a legitimidade passiva da demanda, podendo ser proposta em relação a quaisquer pessoas físicas ou jurídicas, de direito público ou privado.

Julgado procedente o litígio, o administrador público deverá sanar o ato impugnado, retornando ao estado anterior, respondendo ainda por possíveis danos patrimoniais. Sendo a sentença julgada improcedente, somente produzirá efeito jurídico após a confirmação em segunda instância, que deverá ser de ofício, caso as partes não apresentem o recurso.

A ação popular e a ação civil pública são instrumentos aptos de Controle Social à disposição da sociedade como uma possibilidade, dependendo exclusivamente da livre iniciativa do cidadão ou de instituição organizada apta para esse fim.

\subsection{Conselhos de Saúde}

O Conselho de Saúde possui peculiaridade diversa, pois nele o Controle Social é regulamentado por Lei e impõe uma obrigação legal ao conselheiro participante. Não possui caráter discricionário.

A Constituição Federal de 1988 foi o marco inicial de um novo conceito de Controle Social na gestão pública, ao instituir os Conselhos gestores, em especial os Conselhos de Saúde, como órgãos deliberativos e permanentes.

Os Conselhos de Saúde foram regulamentados no início dos anos 1990, inaugurando uma nova fase da política de saúde pública no Brasil, quando o gestor público passou a compartilhar suas responsabilidades do setor de saúde com os representantes da sociedade.

Inicialmente previsto no artigo 198 da Constituição Federal (BRASIL, 1988) os Conselhos de Saúde foram regulamentados pelas Leis 8080/90 e 8142/90 (BRASIL, 1990) as quais estabeleceram os mecanismos de Controle Social de forma institucional, ao regulamentar seu funcionamento como órgão colegiado de atuação permanente. 
As atribuições dos Conselhos de Saúde são inusitadas, pois participam da elaboração, fiscalizam a execução das políticas públicas de saúde, além de deliberarem quanto à aprovação das prestações de conta do setor de saúde.

Essa peculiaridade do Conselho de Saúde como instrumento de Controle Social, tem colocado o Brasil como modelo para outros países, de acordo com Escorel (2008).

A Lei 8.142/90 (BRASIL, 1990), que instituiu os Conselhos de Saúde, definiu questões basilares, como a proporção dos participantes; assim, a representação dos usuários do SUS deve ser paritária (50\%) em relação ao conjunto dos demais segmentos. A Lei supracitada determinou também a autonomia dos Conselhos de Saúde em estabelecer regimentos próprios, a fim de definir seus funcionamentos, nos termos do artigo $1^{\circ}$, $\S 4^{\circ}$ e $\S 5^{\circ}$ da Lei 8.142/90 (BRASIL, 1990).

A percepção dos membros do Conselho de Saúde como parte integrante e essencial para a elaboração das políticas de saúde muitas vezes é ofuscada ou simplesmente comutada em um analista de contas, perdendo importante prerrogativa social:

Eu acho que precisaria haver uma formação, orientação aos conselheiros para que eles realmente entendam o papel deles no Conselho, quais são suas prerrogativas, até onde eles podem ir. O que se observa é que a maioria dos conselheiros não entende, não se aprofunda muito nos assuntos, não procura entender o porquê das coisas. ${ }^{T 4}$

As atribuições e funções dos Conselhos de Saúde foram mais bem especificadas pela Lei Complementar 141/12 (LC 141/12) (BRASIL, 2012), que estabeleceu mecanismos de avaliação, fiscalização e controle do setor saúde nas três esferas de governo, sem prejuízo de outros meios de controle criados por legislação anterior.

Os Conselhos de Saúde, no limite de suas competências, deverão avaliar quadrimestralmente a prestação de contas da execução orçamentária e financeira do setor saúde, assim como o relatório do gestor público sobre as condições e qualidade dos serviços de saúde prestados à população, encaminhando ao chefe do Poder Executivo do respectivo ente da Federação parecer consubstanciado. Contudo, observa-se um cenário diferente no cotidiano pesquisado, conforme relato de um conselheiro pesquisado: 
Às vezes, falando enquanto funcionário da Secretaria, eu tenho a sensação de que as fiscalizações de contas pouco ocorrem ou não ocorrem. ${ }^{G 3}$

O não cumprimento dessas atribuições impostas ao Conselho de Saúde implica em graves irregularidades legais, conforme previsão do artigo 46 da LC 141/12 (BRASIL, 2012).

O conselheiro, membro do Conselho de Saúde, seja ele eleito ou designado pelo gestor público, possui os atributos de agente público, nos termos da definição imposta pela Lei 8.429/92 (BRASIL, 1992).

Diante disso, Santos (2012) é incisivo ao afirmar a condição do conselheiro, membro do Conselho de Saúde, como agente público, sujeito a todas as normas e regulamentações cabíveis.

O cidadão ao ser empossado como membro do Conselho de Saúde torna-se um agente público, assumindo todas as suas prerrogativas e responsabilidades legais, nas esferas administrativas, criminal e civil, pelo descumprimento de suas atribuições, conforme previsão do artigo 46 da LC 141/2012 (BRASIL, 2012), sujeito às infrações previstas nos dispositivos legais: Decreto-Lei 2.848/40 (Código Penal), a Lei 1.079/50, o Decreto-Lei 201/67, a Lei 8.429/92 e demais normas da legislação pertinente. 

7 CONSIDERAÇÕES FINAIS 



\section{CONSIDERAÇÕES FINAIS}

As funções atribuídas aos Conselhos de Saúde são de extrema complexidade técnica, pois exigem conhecimento contábil, administrativo, jurídico além de outros específicos.

É imprescindível que os membros do Conselho de Saúde estejam preparados e capacitados, especialmente no exercício do Controle Social, proporcionando à comunidade uma política de saúde pública adequada e eficiente.

O legislador pátrio, ao estabelecer as normas e diretrizes do setor saúde, teve a preocupação de que fossem elaboradas políticas públicas eficazes e eficientes, pois, além de definir parâmetros do financiamento público, instituiu os mecanismos de fiscalização e Controle Social, sem prejuízo das atribuições de outras instituições político-administrativas de controle externo como o Ministério Público e o Tribunal de Contas.

Observa-se a falta de percepção na maioria dos conselheiros pesquisados quanto a uma das principais funções do Conselho de Saúde, que é a participação direta nas decisões que definem as prioridades e os programas de atuação do gestor público. Contudo, é importante ressaltar que o planejamento, a execução e a fiscalização desses programas devem atender às normatizações legais, as quais definem a discricionariedade do poder executivo.

Os representantes das categorias que compõem o Conselho Municipal de Saúde de Bauru (usuário, trabalhadores e gestores) relatam a falta de preparo dos Conselheiros para o acompanhamento do financiamento e das despesas, pois as planilhas apresentadas pela Secretaria Municipal de Saúde nem sempre são compreensíveis a todos e são apresentadas sem tempo hábil para uma análise detalhada.

O modelo descentralizado de gestão da saúde pública no Brasil transferiu ao poder local autonomia e responsabilidade no desenvolvimento das políticas públicas de saúde, pois nos modelos administrativos anteriores as decisões eram engessadas pela burocracia e distantes da realidade da população.

A autonomia de gestão foi definida dentro de parâmetros objetivos, pois os projetos, além de atender as necessidades locais da comunidade, devem observar 
critérios técnicos e as determinações legais, em harmonia com as políticas sociais das demais esferas de governo.

A reestruturação do setor saúde, com a gestão regionalizada das políticas públicas, também instituiu os Conselhos de Saúde como órgãos deliberativos e permanentes, especialmente com a função de promover o Controle Social.

Ao analisarmos em um contexto mais amplo, observamos que as funções do Conselho de Saúde são extremamente complexas, pois incluem a responsabilidade de conhecer, analisar, julgar, cobrar e divulgar os programas de saúde. Considerando a complexidade dessas funções, impõe-se a necessidade de uma qualificação técnica e uma estrutura adequada para execução das tarefas.

Cabe salientar, no entanto, que tal circunstância não exime os membros do Conselho de Saúde do integral cumprimento das normas legais e a aplicação de critérios técnicos no desempenho de suas funções. Contudo é nítida a falta de percepção do conselheiro quanto a sua atuação como agente público, sujeito a suas prerrogativas e regulamentações.

No presente estudo observou-se que existe uma percepção por parte dos conselheiros quanto ao despreparo e a falta de qualificação, principalmente em relação à legislação e a estrutura do SUS, o que dificulta o desempenho de suas atividades de Controle Social. 


\section{REFERÊNCIAS}





\section{REFERÊNCIAS}

ARAÚJO, E. N. Curso de Direito Administrativo. São Paulo: Saraiva, 2005.

AGUIAR JR, R. R. de. O acesso do consumidor à Justiça do Brasil. Revista de Direito do Consumidor, n 16., p 23, out/dez 1995.

ALMEIDA, G. A. Direito processual coletivo brasileiro: um novo ramo do direito processual. São Paulo: Saraiva, 2003. p. 393.

ALVIM, A. Ação popular. Revista de Processo, São Paulo, n. 32, 1983.

ALVIM, E. A. Apontamentos sobre o processo das ações coletivas. In: MAZZEI, R.; NOLASCO, R. (Orgs.). Processo civil coletivo. São Paulo: Quartier Latin, 2005. p. 48,64 .

AMARAL, G. Direito, escassez e escolha. Rio de Janeiro: Renovar, 2001. p. 214215.

BANDEIRA DE MELLO, C. A. Curso de Direito Administrativo. 13. ed. São Paulo: Malheiros, 2001. p. 72-73.

BARBOSA MOREIRA, J. C. Ações coletivas na Constituição Federal de 1988. Revista do Processo, São Paulo, n. 61, 1991.

BARROSO, L. R. O controle de constitucionalidade no direito brasileiro: exposição sistemática da doutrina e análise crítica da jurisprudência. 2. ed. São Paulo: Saraiva, 2006.

BIELSA, R. A ação popular e o poder discricionário da administração. Revista Forense, v. 52, n. 157, p.34-49, jan./fev. 1955.

BOBBIO, N. O futuro da democracia. 8. ed. Rio de Janeiro: Paz e Terra, 2002.

BAURU, http://www.bauru.sp.gov.br/. Acesso em 15/11/2015

BRASIL. O SUS de A a Z: garantindo saúde nos municípios. Brasília: Ministério da Saúde, 2006. 
Saúde, 2013.

Para entender o Controle Social na saúde. Brasília, DF: Ministério da

Constituição da República Federativa do Brasil (1988). Brasília, DF:

Casa Civil, Subchefia para Assuntos Jurídicos. Disponível em: <http://www.planalto.gov.br/ccivil 03/constituicao/constituicao.htm>. Acesso em: 3 maio 2014.

. Constituição Política do Império do Brazil (1824). Brasília, DF: Casa Civil, Subchefia para Assuntos Jurídicos. Disponível em: <http://www.planalto.gov.br/ccivil 03/constituicao/constituicao24.htm>. Acesso em: 3 maio 2014.

Constituição da República dos Estados Unidos do Brasil (1934). Brasília, DF: Casa Civil, Subchefia para Assuntos Jurídicos. Disponível em: <http://www.planalto.gov.br/ccivil 03/constituicao/constituicao34.htm>. Acesso em: 3 maio 2014.

Lei $n^{\circ}$ 8.142, de 28 de dezembro de 1990. Dispõe sobre as transferências intergovernamentais de recursos financeiros na área da saúde e outras providências. Diário Oficial da União, 31 dez. 1990.

Lei $n^{\circ}$ 4.717, de 29 de junho de 1965. Brasília, DF: Casa Civil, Subchefia para Assuntos Jurídicos. Disponível em: <http://www.planalto.gov.br/ccivil_03/Leis/L4717.htm>. Acesso em: 3 maio 2014.

Lei $n^{\circ}$ 5.869, de 11 de janeiro de 1973 Brasília, DF: Casa Civil, Subchefia para Assuntos Jurídicos. Disponível em: <http://www.planalto.gov.br/>. Acesso em: 3 maio 2014..

Lei $n^{\circ}$. 7.347, de 24 de julho de 1985. Brasília, DF: Casa Civil, Subchefia para Assuntos Jurídicos. Disponível em: <http://www.planalto.gov.br/ >. Acesso em: 3 maio 2014.

Lei 8.078 de 1990, Brasília, DF: Casa Civil, Subchefia para Assuntos Jurídicos. Disponível em: <http://www.planalto.gov.br/>. Acesso em: 3 maio 2014.

CARVALHO, A. I. Conselhos de Saúde no Brasil: participação e Controle Social. Rio de Janeiro: FASE/IBAM, 1995.

COELHO, V. S. P. Conselhos de saúde enquanto instituições políticas: o que está faltando? In: COELHO, V. S. P; NOBRE, M. (Orgs.). Participação e deliberação: 
teoria democrática e experiências do Brasil contemporâneo. São Paulo: Editora 34, 2004. p. 255-267.

CORREAA TELLES, J. H. Doutrina das ações. Rio de Janeiro: Jacintho Ribeiro dos Santos Editor, 1918. § 14, p. 44.

CORREIA, M. V. C. Dicionário da educação profissional em saúde. Rio de Janeiro: Editora Fiocruz, 2009.

CRETELLA JÚNIOR, J. Tratado de Direito Administrativo. Rio de Janeiro: Forense, 1970.

CUNHA JÚNIOR, D. Curso de Direito Administrativo. 4. ed. Salvador: JusPodivm, 2006. p. 208.

DALLARI, D. de A. O renascer do direito. São Paulo: Saraiva, 1990.

DALLARI, S. G. et al. O direito à saúde na visão de um conselheiro municipal de saúde. Caderno Saúde Pública, n.12, p. 531-540, 1996.

DINAMARCO, P. S. Ação civil pública. São Paulo: Saraiva, 2001.

DI PIETRO, M. S. Z. Direito Administrativo. 17. ed. São Paulo: Atlas, 2004. p. 431.

. Temas polêmicos sobre licitações e contratos. 5. ed. São Paulo: Malheiros , 2006.

. Direito Administrativo. 20. ed. São Paulo: Atlas, 2007.

DUARTE, R. Cadernos de Pesquisa, n. 115, mp. a1rç3o9/-125040,2 mar. 2002.

ESCOREL S. Conselhos de saúde: entre a inovação e a reprodução da cultura política. Saúde Debate, p. 23-28, 2008.

FAZZIO JUNIOR, W. Improbidade administrativa e crimes de prefeitos. São Paulo: Editora Atlas S.A., 2000.

FERREIRA, B. H. Mini Aurélio século XXI: O minidicionário da Língua Portuguesa. Rio de Janeiro: Nova Fronteira, 2000. 
GAMA, R. R. Dicionário básico jurídico. Campinas: Russell, 2006.

GERSCHMAN S. Conselhos Municipais de Saúde: atuação e representação das comunidades populares. Caderno Saúde Pública, Rio de Janeiro, n. 20(6), nov-dez, 2004, p. 1670-1681.

GOMES JUNIOR, L. M. Ação popular: aspectos polêmicos. Rio de Janeiro: Editora Forense, 2004.

GONÇALVES, M. L.; ALMEIDA, M. C. P. Construindo o Controle Social e a cidadania em uma experiência concreta: o Conselho Municipal de Saúde de Ribeirão Preto (SP). Revista Saúde em Debate, Rio de Janeiro, v. 26, n. 61, 2002.

GRISOTTI, M.;ZULEICA, P.; Maria and Silva, Andréia da . A participação de usuários, trabalhadores e conselheiros de saúde: um estudo qualitativo. Ciência saúde coletiva, v.15, n.3, p.831-840, maio 2010.

GUIZARDI, F. L.; PINHEIRO, R. Dilemas culturais, sociais e políticos da participação dos movimentos sociais nos Conselhos de Saúde. Ciência \& Saúde Coletiva, n. 11, p. 797-805, 2006.

GURZA, L. A.; ISUNZA, V. E. A trama da crítica democrática: da participação à representação e à accontabillity. São Paulo, Lua Nova, 2011. p. 353-364.

IBGE, http://cod.ibge.gov.br/233EA. Acesso em 15/11/2015.

HORTA, R. M. Improbidade e corrupção. Revista de Direito Administrativo. Rio de Janeiro: Livraria e Editora Renovar, 2004. v. 236.

LEFEVRE, F.; LEFEVRE, A. M. C. Comunicação, Saúde, Educação, v.10, n. 20, p.517-524, jul./dez. 2006.

Discurso do sujeito coletivo, complexidade e auto-organização. Ciências e Saúde Coletiva, n. 14, p. 1193-1204, 2009.

O discurso do sujeito coletivo: um novo enfoque em pesquisa qualitativa (desdobramentos). Caxias do Sul: EDUCS, 2003.

LONGHI, J. C.; CANTON, G. A. M. Reflexões sobre cidadania e os entraves para a participação popular no SUS. Physis Revista de Saúde Coletiva, Rio de Janeiro, n.21, p. 15-30, 2011. 
LUCHMANN, LHH. Os Conselhos gestores de políticas públicas: desafios do desenho institucional. Revista de Ciências Sociais Unisinos, p. 43-79, 2002.

MANCUSO, R. C. Ação popular. 5. ed. rev. atual. e ampl. São Paulo: Revista dos Tribunais, 2003. p. 62.

MANNHEIM, K. Sociologia sistemática: uma introdução ao estudo de sociologia. 2. ed. São Paulo: Pioneira, 1971.

MARTINS, C. S. et al. Conhecimento dos usuários, trabalhadores da saúde e gestores sobre conselheiros e Conselhos de Saúde. Saúde em Debate. Rio de Janeiro, v. 37, n. 98, p. 437-445, jul./set. 2013.

MEDAUAR, O. Direito Administrativo Moderno. São Paulo: Editora Revista dos Tribunais, 1999.

MEDINA, P. R. G. Direito processual constitucional. Rio de Janeiro: Forense, 2006. p. 121-122.

MEIRELLES, H. L. Mandado de segurança. 16. ed. São Paulo: Malheiros, 1995.

. Direito Administrativo Brasileiro. 29. ed. São Paulo: Malheiros, 2004. p. 222.

MELLO, C. A. B. Curso de Direito Administrativo. 15. ed. São Paulo: Malheiros, 2003. p. 226 e 227.

MENDES, G. F. Ação Civil Pública e controle de constitucionalidade. In: Arnoldo

WALD, A. (Coord.). Aspectos polêmicos da Ação Civil Pública. 2. ed. São Paulo: Saraiva, 2007. p. 151-165.

MORAES, A. Direito Constitucional. São Paulo: Editora Atlas, 1999.

. Constituição do Brasil interpretada e legislação constitucional. São Paulo: Atlas, 2006.

. Direito Constitucional. 24. ed. São Paulo: Atlas, 2009. p. 185. 
MOREIRA, M. L. Consolidação dos conselhos municipais de saúde depende de superação dos desafios. Agência Fiocruz de Notícias, 24 jul. 2007.

NOGUEIRA-MARTINS, M. C. F.; BÓGUS, C. M. Saúde e Sociedade, v. 13, n. 3, p. 44-57, set.-dez., 2004.

REIS, U. L. S. Ação popular constitucional. Revista Jus Navigandi, Teresina, ano 19, n. 3.969, 14 maio 2014. Disponível em: <http://jus.com.br/artigos/28396>. Acesso em: 12 jul. 2015.

SANTOS, L. SUS e a Lei Complementar 141 comentada. 2. ed. Campinas: Saberes, 2012. p. 158.

SANTOS, M. M. Legitimidade na ação civil pública. Revista Jus Navigandi, Teresina, ano 5, n. 45, 1 set. 2000. Disponível em: <http://jus.com.br/artigos/348>. Acesso em: 13 ago. 2015.

SILVA, J. A. Ação popular constitucional. 2. ed. rev. ampl. São Paulo: Malheiros, 2007.

1998. p. 349 e 462.

Curso de Direito Constitucional Positivo. 15. ed. São Paulo: Malheiros,

SIQUEIRA JR., P. H. Direito processual constitucional. 6. ed. São Paulo: Saraiva, 2012.

STF. Súmula nº 365 - 13/12/1963 - Súmula da Jurisprudência Predominante do Supremo Tribunal Federal.

SPOSATI A.; LOBO, E. Controle Social e políticas públicas. Cadernos de Saúde Pública, v. 4, n. 8, p. 366-378, 1992.

VÁZQUEZ, M. L. et al. Nível de informação da população e utilização dos mecanismos institucionais de participação social em saúde em dois municípios do Nordeste do Brasil. Ciências. saúde coletiva, v. 10, p. 141-155, dez. 2005.

VICTOR, R. A. O controle de constitucionalidade em sede de ação civil pública. Revista Jus Navigandi, Teresina, ano 13, n. 1692, 18 fev. 2008. Disponível em: <http://jus.com.br/artigos/10951>. Acesso em: 13 ago. 2015.

WALINE, M. Droit Administratif. 9. ed. Paris: Éditions Sirey, 1963. 
APÊNDICE 



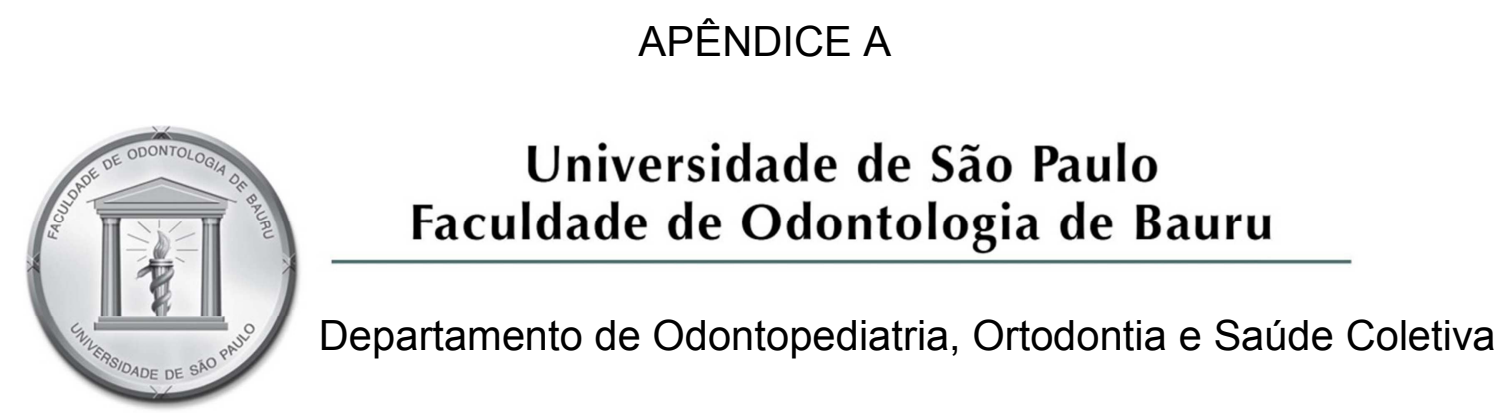

Convido o Sr. (a).

portador da cédula de identidade RG

a participar de uma pesquisa acadêmica que tem por objetivo avaliar a eficiência do controle das políticas de saúde pública, especialmente mediante o controle social, na perspectiva dos representantes do Conselho Municipal de Saúde, Ministério Público e do Tribunal de Contas, lotados no Município de Bauru.

O resultado dessa pesquisa poderá contribuir para o desenvolvimento e aprimoramento às instituições participantes, no desenvolvimento e aprimoramento do controle das Políticas de Saúde Públicas. Como método de coleta de dados, será realizada uma entrevista gravada em local e data previamente agendados, com duração aproximada de 30 minutos.

O risco consiste no desconforto diante do tema abordado e o tempo dedicado em colaborar com a pesquisa, não haverá um benefício individual imediato, mas contribuirá significantemente com informações importantes para o desenvolvimento das Políticas de Saúde Pública.

Esse documento será apresentado em duas vias devidamente assinado e rubricado, sendo uma para o entrevistado e a outra que será mantida em arquivo pelo pesquisador.

A participação é livre e o entrevistado pode, a qualquer momento retirar seu consentimento, deixando de participar desta pesquisa sem qualquer prejuízo.

Será mantido o anonimato do entrevistado, sendo que todas as informações individuais prestadas serão confidenciais e guardadas por força de sigilo profissional nos termos dos artigos7, 33 e 54, V, da Lei $n^{\circ}$ 8.906, de 04 de julho de 1994, combinados com os artigos 25 a 27 do Código de Ética e Disciplina da Ordem dos Advogados do Brasil, assegurando que a a posterior publicação dos resultados desse trabalho não permitirá a identificação dos participantes.

Uma via do presente TERMO DE CONSENTIMENTO será entregue ao participante da pesquisa.

O entrevistado não terá qualquer despesa, não havendo ressarcimento.

Havendo algum prejuízo ao participante, em decorrência da pesquisa, o mesmo será indenizado pelo pesquisador.

Pelo presente instrumento que atende às exigências legais, o Sr. (a)

portador da cédula de identidade , após leitura minuciosa das informações constantes neste TERMO DE CONSENTIMENTO LIVRE E ESCLARECIDO, devidamente explicada pelos profissionais em seus mínimos detalhes, ciente dos serviços e procedimentos aos quais será submetido, não restando quaisquer dúvidas a respeito do lido e explicado, DECLARA e FIRMA seu CONSENTIMENTO LIVRE E ESCLARECIDO concordando em participar da pesquisa proposta. Fica claro que o participante da pesquisa, pode a qualquer momento retirar seu CONSENTIMENTO LIVRE E ESCLARECIDO e deixar 
de participar desta pesquisa e ciente de que todas as informações prestadas tornar-se-ão confidenciais e guardadas por força de sigilo profissional (sigilo profissional nos termos dos artigos7, 33 e 54, V, da Lei $n^{\circ}$ 8.906, de 04 de julho de 1994, combinados com os artigos 25 a 27 do Código de Ética e Disciplina da Ordem dos Advogados do Brasil).

Por fim, como pesquisador responsável pela pesquisa, DECLARO o cumprimento do disposto na Resolução CNS n 466 de 2012, contidos nos itens IV.3 e item IV.5.a e na íntegra com a resolução CNS nº 466 de dezembro de 2012.

Bauru, SP, de de

Pesquisador responsável: Marimárcio Matos Corsino Petrúcio - Rua Raposo Tavares, 11-62, Bauru, SP. (14) 99745-0033 e-mail: marimarcio@usp.br

O Comitê de Ética em Pesquisa - CEP, organizado e criado pela FOB-USP, em 29/06/98 (Portaria GD/0698/FOB), previsto no item VII da Resolução n 466/12 do Conselho Nacional de Saúde do Ministério da Saúde (publicada no DOU de 13/06/2013), é um Colegiado interdisciplinar e independente, de relevância pública, de caráter consultivo, deliberativo e educativo, criado para defender os interesses dos participantes da pesquisa em sua integridade e dignidade e para contribuir no desenvolvimento da pesquisa dentro de padrões éticos.

Qualquer denúncia e/ou reclamação sobre sua participação na pesquisa poderá ser reportada a este CEP:

\section{Horário e local de funcionamento:}

Comitê de Ética em Pesquisa

Faculdade de Odontologia de Bauru-USP - Prédio da Pós-Graduação (bloco E - pavimento superior), de segunda à sexta-feira, no horário das $14 \mathrm{~h}$ às 17 horas, em dias úteis.

Alameda Dr. Octávio Pinheiro Brisolla, 9-75

Vila Universitária - Bauru - SP - CEP 17012-901

Telefone/FAX(14)3235-8356

e-mail: cep@fob.usp.br 


\section{APÊNDICE B \\ Questionário da pesquisa - Conselheiro Municipal}

1. Já participou anteriormente de algum outro projeto social, mesmo não ligado à área da saúde?

2. Como foi que conheceu as atividades do Conselho Municipal de Saúde?

3. Qual seguimento o(a) senhor(a) representa?

4. Há quanto tempo já atua como conselheiro?

5. No período em que está atuando como conselheiro, já foi oferecido algum tipo de treinamento ou capacitação pela administração pública ou alguma instituição particular?

6. Além das reuniões ordinárias do conselho, existe algum outro tipo de evento regional, encontros, congressos ou algo parecido?

7. Nas reuniões ordinárias como é feita a convocação? É enviada a pauta com antecedência para uma análise prévia?

8. Quando surge alguma dúvida na pauta como é o acesso à Secretaria Municipal de Saúde?

9. Existe alguma assessoria técnica de apoio ao Conselho Municipal de Saúde, tais como contábil, jurídica, administrativa ou outra?

10. Quando são apreciadas as contas da Secretaria Municipal de Saúde a votação registra os votos favoráveis e os contrários de forma individual?

11. Existe algum tipo de intercâmbio entre o Conselho Municipal de Saúde, o Ministério Público; (se sim) Como funciona?

12. A atual estrutura do Conselho de Saúde é suficiente para desenvolver as atividades de fiscalização das atividades da Secretaria de Saúde? Comente.

13. Em sua opinião, o que deveria ser mudado para tornar o trabalho do Conselho de Saúde mais eficiente?

14. Em sua opinião, quais são os aspectos mais importantes como conselheiro?

15. Você considera que uma capacitação ajudaria no desempenho da atividade de conselheiro?

16. $O$ (a) senhor(a) gostaria de acrescentar algum comentário sobre o Conselho Municipal de Saúde? 


\section{APÊNDICE C}

\section{Analise das expressões-chave e ideias centrais}

\begin{tabular}{|c|c|c|}
\hline EC & IC & Ancoragem \\
\hline $\begin{array}{l}\text {... porque tem conselheiro que não sabe nem } \\
\text { que papel ele está fazendo, nem porque ele } \\
\text { está nisso. U1 } \\
\text {... Então, a nossa dificuldade hoje é ter } \\
\text { conselheiro realmente capacitado para ser } \\
\text { conselheiro. Tem muitos de boa vontade, mas } \\
\text { nem todos têm conhecimento para isso... o } \\
\text { conselheiro deveria ser assim, porque ele não } \\
\text { tem noção do que é ser um conselheiro. U2 }\end{array}$ & $\begin{array}{l}\text { Falta de preparo } \\
\text { para as atividades } \\
\text { de conselheiro }\end{array}$ & $\begin{array}{lr}\text { OLIVEIRA, } & \text { AMC, } \\
\text { Pereira PCM. Uma } \\
\text { estratégia para a } \\
\text { formulação } \\
\text { políticas de saúde. } \\
\begin{array}{l}\text { Pensar BH/Política } \\
\text { Social2011 }\end{array}\end{array}$ \\
\hline $\begin{array}{l}\text { Porque eu observo assim, que também o } \\
\text { conselheiro, ele tem que ter conhecimento na } \\
\text { hora daquele assunto, porque, às vezes a } \\
\text { gente percebe que tem pessoas que ela } \\
\text { participa, mas com um desconhecimento } \\
\text { daquilo que acontece. Ela participa, ela fala, } \\
\text { às vezes até tumultua a reunião, mas porque } \\
\text { ela não tem conhecimento daquilo ou preparo } \\
\text { de como é realizado aquilo... que às vezes a } \\
\text { pessoa está ali, mas ela está despreparada } \\
\text { realmente para aquilo }\end{array}$ & & \\
\hline $\begin{array}{l}\text {... porque eu acho que falta um pouco de } \\
\text { conhecimento neste sentido, de como } \\
\text { fiscalizar, o que fiscalizar... Eu penso que falta } \\
\text { um entendimento maior. Acho que eles não } \\
\text { fiscalizam por falta de conhecimento. G3 }\end{array}$ & & \\
\hline $\begin{array}{l}\text { Eu acho que precisaria haver uma formação, } \\
\text { orientação aos conselheiros para que eles } \\
\text { realmente entendam o papel deles no } \\
\text { Conselho, quais são suas prerrogativas, até } \\
\text { onde eles podem ir. O que se observa é que a } \\
\text { maioria dos conselheiros não entende, não se } \\
\text { aprofunda muito nos assuntos, não procura } \\
\text { entender o porquê das coisas. O ideal é, } \\
\text { lógico, que cada um se debruçasse sobre os } \\
\text { documentos antes de chegar na reunião, mas } \\
\text { a maioria das pessoas não tem preparo para } \\
\text { analisar este tipo de documento, balanços ou } \\
\text { propostas para poder chegar na reunião com } \\
\text { uma opinião formada T4 }\end{array}$ & & \\
\hline $\begin{array}{l}\text {... a maioria dos conselheiros não tem } \\
\text { capacitação nenhuma, então, a gente tem }\end{array}$ & & \\
\hline
\end{tabular}




\begin{tabular}{|c|c|c|}
\hline $\begin{array}{l}\text { dificuldade em aprovar as contas... Então, } \\
\text { assim, é falta de preparo dos conselheiros. }{ }^{T 5}\end{array}$ & & \\
\hline $\begin{array}{l}\text { Creio que qualquer tipo de capacitação ajuda. } \\
\text { G2 } \\
\text { Uma capacitação nesse sentido penso que } \\
\text { poderia ajudar... uma necessidade, com os } \\
\text { municípios da região, de participação, de } \\
\text { capacitação para uma participação mais } \\
\text { efetiva, até para que eles entendam qual é o } \\
\text { verdadeiro papel deles enquanto conselheiros } \\
\text { de saúde. G3 }\end{array}$ & $\begin{array}{l}\text { Necessidade } \\
\text { de capacitação } \\
\text { para o conselheiro }\end{array}$ & 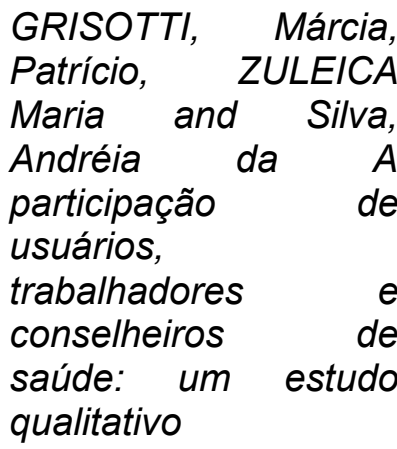 \\
\hline $\begin{array}{l}\text { A capacitação ajudaria muito. Até nisso que } \\
\text { eu estou falando, do despreparo da pessoa. É } \\
\text { bem-vinda a capacitação. }\end{array}$ & & \\
\hline $\begin{array}{l}\text { Então, sinto que uma capacitação é } \\
\text { fundamental. Acho que deveria ser assim... } \\
\text { deveria ser como se fosse uma condição para } \\
\text { você continuar como conselheiro. }{ }^{T 2}\end{array}$ & & \\
\hline $\begin{array}{l}\text { Capacitação, com certeza. Eu acho que } \\
\text { deveria ter mais treinamento para que as } \\
\text { pessoas, na verdade, soubessem as } \\
\text { atribuições que Ihe competem e desempenhá- } \\
\text { las com mais segurança, tranquilidade. T3 }\end{array}$ & & \\
\hline $\begin{array}{l}\text { Não seria uma, seriam várias capacitações } \\
\text { que deveria ser feito mesmo, periodicamente, } \\
\text { não só falar, mas teria que ter uma } \\
\text { capacitação periódica e mais objetiva e } \\
\text { qualificada para que o conselheiro realmente } \\
\text { entenda, primeiro, que ele entenda seu papel, } \\
\text { para que ele possa levar esse entendimento } \\
\text { do que é função dele para a sociedade para } \\
\text { que a sociedade conheça e entenda o que é } \\
\text { um Conselho. }{ }^{\text {Th }}\end{array}$ & & \\
\hline Seria muito bom uma capacitação. ${ }^{\cup 4}$ & & \\
\hline $\begin{array}{l}\text { A capacitação é importante para você } \\
\text { entender quais são as suas obrigações ou } \\
\text { pelo menos o seu compromisso inicial, mas } \\
\text { teria que ter alguma coisa de formação de } \\
\text { natureza continuada. }{ }^{61}\end{array}$ & & \\
\hline $\begin{array}{l}\text { Os conselheiros, mesmo, que representa a } \\
\text { grande maioria da população, é até triste eu } \\
\text { falar isso, mas o que eu faço uma leitura }\end{array}$ & $\begin{array}{l}\text { O Conselho de } \\
\text { Saúde como } \\
\text { palanque politico }\end{array}$ & $\begin{array}{l}\text { A Contribuição da } \\
\text { Pesquisa - Avaliação } \\
\text { para o Processo de } \\
\text { Implementação do }\end{array}$ \\
\hline
\end{tabular}




\begin{tabular}{|c|c|c|}
\hline $\begin{array}{l}\text { existe um interesse muito político, então eu } \\
\text { quero ir lá, mostrar que eu sei brigar, que eu } \\
\text { quero fazer, porque eu tenho um interesse } \\
\text { futuro, talvez, em ser conhecido, em alguém } \\
\text { votar em mim, sei lá. Porque, às vezes, a } \\
\text { questão política interfere muito... Infelizmente, } \\
\text { as pessoas misturam ser conselheiro com ser } \\
\text { político, e aí a gente não sai daquele lugar } \\
\text { Os conselheiros, por sua vez, alguns deles } \\
\text { Os cabam ocupando os espaços simplesmente } \\
\text { para fazer palanque eleitoral. T5 }\end{array}$ & & $\begin{array}{lll}\text { Controle } & \text { Social no } \\
\text { SUS } & & \end{array}$ \\
\hline $\begin{array}{l}\text { mas também a questão da disponibilidade, } \\
\text { porque a maior parte das pessoas trabalha. } \\
\text { Isso é um limitante também, é um fator } \\
\text { limitante. }{ }^{2} \\
\text { Por exemplo, é só uma coisa que é irritante, } \\
\text { tem uma chamada às } 19 h \text {, não tem ninguém; } \\
\text { tem uma chamada às 19h30, não tem } \\
\text { ninguém. Quinze para as 20h, o pessoal } \\
\text { começa a chegar, nós fomos convocados para } \\
\text { as } 19 h \text {. Então, existe essa... e é sempre } \\
\text { aquelas pessoas que são representantes da } \\
\text { Casa do Conselho que chegam às } 21 h \text {. Então, } \\
\text { essas coisas são muito ruins, porque a gente } \\
\text { trabalha o dia inteiro, o pessoal da Secretaria } \\
\text { da Saúde também, a gente vê que eles ficam } \\
\text { lá direto. O pessoal que vem mesmo, que } \\
\text { deveria estar representando, que era quem } \\
\text { mais deveria estar ali, eu não sinto muito } \\
\text { essa... sabe? Hoje eu vejo que o Conselho de } \\
\text { Saúde ele é feito pelos funcionários da } \\
\text { Secretaria da Saúde e as instituições que } \\
\text { prestam serviço, porque os conselheiros, } \\
\text { mesmo, muito pouco. Tem conselheiro lá que } \\
\text { começou no começo do ano e nunca mais eu } \\
\text { vi. } \\
\text { Gostaria que os membros eleitos fossem mais } \\
\text { atuantes e participativos, comprometidos com } \\
\text { o cargo que os mesmos se disponibilizaram a } \\
\text { aceitar, porque eu só sou conselheira porque } \\
\text { eu me disponibilizei a estar lá. E se eu me } \\
\text { disponibilizei a estar lá, por que eu não estou? } \\
\text { Na verdade, não muda em nada a minha vida } \\
\text { profissional eu estando lá ou não estando, } \\
\text { mas, com certeza, se eu me disponibilizei } \\
\text { estar e não estou, com certeza eu vou fazer } \\
\text { falta na hora das votações. Porque às vezes a } \\
\text { gente fica esperando dar quórum para que a } \\
\text { gente comece as reuniões. Então, se você } \\
\text { não quer ser um conselheiro, não fique } \\
\text { lutando para ser, então... T3 }\end{array}$ & $\begin{array}{ll}\text { Falta } & d e \\
\text { disponibilidade } & d o \\
\text { conselheiro } & \end{array}$ & $\begin{array}{l}\text { Participação cidadã e } \\
\text { controle social nos } \\
\text { conselhos municipais } \\
\text { de saúde da Paraíba. }\end{array}$ \\
\hline
\end{tabular}




\begin{tabular}{|c|c|c|}
\hline $\begin{array}{l}\text { Então, eu entendo que teria que se mudar, } \\
\text { melhorar, a representatividade de usuários } \\
\text { colocando no Conselho conselheiros e } \\
\text { pessoas indicadas por essas entidades que } \\
\text { realmente representassem o interesse do } \\
\text { usuário final. G1 }\end{array}$ & $\begin{array}{l}\text { Falta } \\
\text { representatividade } \\
\text { do usuário }\end{array}$ & 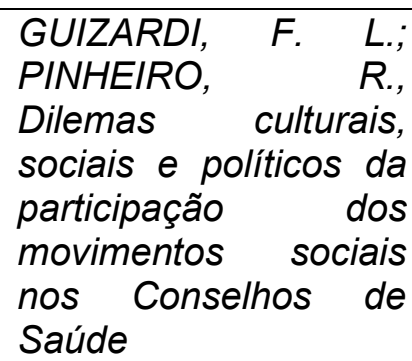 \\
\hline 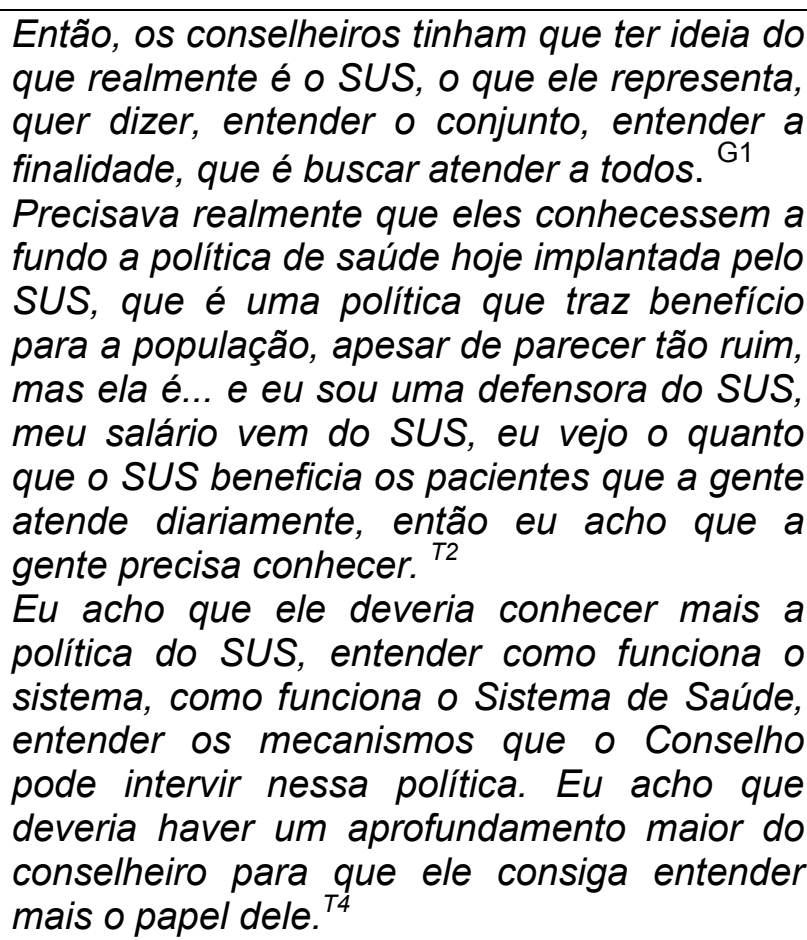 & $\begin{array}{ll}\text { Falta } & d e \\
\text { conhecimento } & d o \\
\text { SUS } & \end{array}$ & $\begin{array}{lr}\text { Nível de informação } \\
\text { da população e } \\
\text { utilização } \\
\text { mecanismos dos } \\
\text { institucionais de } \\
\text { participação social em } \\
\text { saúde em dois } \\
\text { municípios do } \\
\text { Nordeste do Brasil }\end{array}$ \\
\hline $\begin{array}{l}\text { Às vezes, falando enquanto funcionária da } \\
\text { Secretaria, eu tenho a sensação de que as } \\
\text { fiscalizações de contas pouco ocorrem ou não } \\
\text { ocorrem. }\end{array}$ & $\begin{array}{l}\text { Fiscalização das } \\
\text { contas/finanças. }\end{array}$ & $\begin{array}{l}\text { Participação cidadã e } \\
\text { controle social nos } \\
\text { conselhos municipais } \\
\text { de saúde da Paraíba. }\end{array}$ \\
\hline
\end{tabular}



ANEXO 



\section{FACULDADE DE ODONTOLOGIA DE BAURU- USP}

\section{PARECER CONSUBSTANCIADO DO CEP}

\section{DADOS DO PROJETO DE PESQUISA}

Ttulo da Pesqulsa: Controle Soclal no Sistema Unlco de Saude - SUS: Percepçăo sobre a responsabllidade legal dos Conselhos de Saude e seus Integrantes.

Pesqulsador: Marimarcio de Matos Corsino Petrucio

Área Tematica:

Vers30: 1

CAAE: 48748615.5.0000.5417

Instutulça Proponente: Universidade de Sto Paulo - Facuidade de Odontologla de Bauru

Patrocinador Princlpal: Finandamento Propilo

\section{DADOS DO PARECER}

Numero do Parecer: 1.235 .563

\section{Apresentsçato do Projeto:}

O projeto de pesquisa " Controle Soclal no Sistema Unico de Saude - SUS: Percepçăo sobre a responsabllidade legal dos Conselhos de Saude e seus Integrante" apresenta como pesquisador responsavel Marimarcio de Matos Corsino Petrúcio. Seu objettvo visa anallsar a percepç5o de agentes do controle social em saude quanto a fiscal zaçấo do sistema publico de saude e sua efcacia. Para Isso, um trabaho de pesquisa de campo com entrevista audlo-gravada de aproximadamente 30 minuto6, previamente agendada, contendo a informaçăo do entrevistado e um roteiro de perguntas relacionadas a percepçajo da eflcacla dos mecanlsmos de fiscallzaçăo e controle por parte do Conselno Municlpal de Saude e do Ministerio Publico, a fim de verificar sua funclonalldade.

\section{Objetivo da Pesqulsa:}

Oojetvo geral:

- Analsar a percep̧50 de agentes do controle social em saude quanto a fiscalizacáo do sistema publico de saude e sua eflcacia.

Oojetvos especificos:

- Analsar 05 principas temas de interesse segundo o segmento entrevistado.

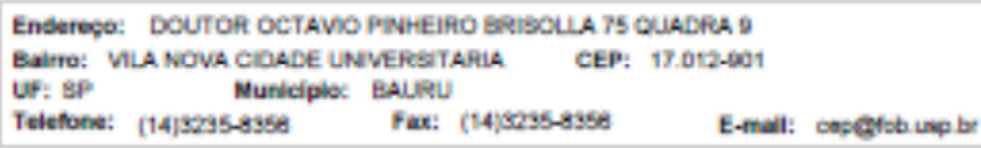




\section{FACULDADE DE ODONTOLOGIA DE BAURU- USP}

Contnacles do Pancer: 1296 wo

- Descrever a apresentaç5̆o de planos na area da saude publica.

- Descrever como e felta a prestaçáo de contas na area da saude.

- Veritcar a necessidade de capacitaç5o/orientaç5o para desempenho da funçâo de Conselhelro Muriclpal de Saúde.

Avallaç30 dos Flscos $\theta$ Beneficlos:

Riscos:

O nisco consiste no descontorto diante do tema abordacio e o tempo dedcado em colaborar com a pesqulsa Beneficlos:

Năo havera um beneficlo Indlvidual Imediato, mas contribulra significantemente com Informaçbes Importantes para o desenvolvimento das Politicas de Saude Publlca

\section{Comentarios $\theta$ Consideraços sobre a Pesquisa:}

A pesquisa taz parte da linha de pesquisa da orlentadora, a Profa. Dra. Nice Emy Tomita, com objetivos descritos e nato apresenta comprometimento etlco.

\section{Consldersç0es sobre 08 Termos de apresentsça obrigatorla:}

Foram apresentados $\propto$ termos: Projeto de pesquisa detalinado, folna de rosto, questionario do pesquisador, termo de encaminhamento do Departamento de Odontopedlatria, Ortodonta e Saude Coletva, declaraçăo dos resultados, termo de aqulescencla do Conselho Muriclpal de Saude de Bauru (SP).

\section{Recomendaços:}

1- Inciulr o nome da ortentadora na equipe de pesquisa da Platafoma Brasl (Prota. Dra. Nice Eny Tomita). 2- Melhor defniçto do tamanho da amostra no projeto (colocar que serహేo 26 participantes).

Conclus 68 ou Pendenclas $\theta$ Llata de Inadequaç0es:

Sugro aprovaçato com recomendaçbes.

Consldersç0es Finals a criterio do CEP:

Esse projeto fol considerado A.PROVADO na reunlăo ordinaria do CEP de 16.09.2015, com base nas nomas eticas da Resoluçăo CNS 466/12. Ao temino da pesquisa o CeP-FOEVUSP exige a apresentaçăo de relatorio final. $O 6$ relatorios parclals deverăo estar de acordo com o cronograma elou parecer emitido pelo CEP. Avteraçbes na metodologla, thulo, Inclusło ou exclusta de autores, cronograma e qualsquer outras mudanças que sejam signilicativas deverăo ser prevlamente comunicadas a este CEP sob risco de năo aprovaçăo do relatơrio fnal. Quando da apresentaçấ

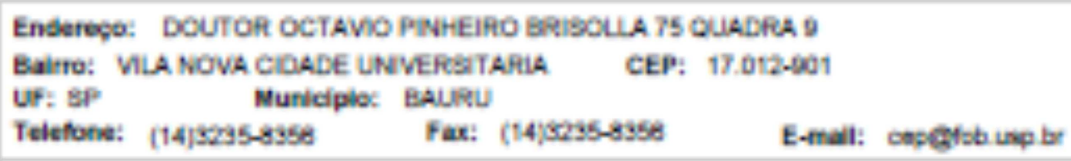




\section{FACULDADE DE ODONTOLOGIA DE BAURU- USP}

Corthacks do Pancer: $1280 \%$

deste, deverdo ser inciuldos todos os TCLEs elou termos de doaç50 assinados e nubricados, se pertinentes.

Este parecer fol elaborado basesdo nos documentos abalxo relacionados:

\begin{tabular}{|c|c|c|c|c|}
\hline Tlpo Docalmento & Arquivo & Postagen & ALITOR & Situaça \\
\hline $\begin{array}{l}\text { Decaraçso de } \\
\text { Pesqulsadores }\end{array}$ & $\begin{array}{l}\text { Decar_compromisso_pesqusacor_com } \\
\text { _resurtados.pdr }\end{array}$ & $\begin{array}{l}1508 / 2015 \\
17: 36: 23\end{array}$ & $\begin{array}{l}\text { Varinarcio de Matos } \\
\text { Corsino Petrucio }\end{array}$ & Acelo \\
\hline $\begin{array}{l}\text { TCLE / Temos de } \\
\text { Assentmento / } \\
\text { Justiflcativa de } \\
\text { Ausencla }\end{array}$ & TCLE pd' & $\begin{array}{c}19 / 08 / 2015 \\
17: 4124\end{array}$ & $\begin{array}{l}\text { Marimarcio de Matos } \\
\text { Corsino Petrudio }\end{array}$ & Acelto \\
\hline $\begin{array}{l}\text { Decarackso de } \\
\text { insttuçaoe } \\
\text { intrastutura }\end{array}$ & Termo_enczmnamento_ceppơ & $\begin{array}{l}1506 / 2015 \\
17: 43: 48\end{array}$ & $\begin{array}{l}\text { Tarmarcio de Matcos } \\
\text { Corsino Petrúcio }\end{array}$ & ACEto \\
\hline Outros & $\begin{array}{l}\text { Questionario_tecnico_projeto_de_pesqu } \\
\text { sa.pdt }\end{array}$ & $\begin{array}{l}19 / 08 / 2015 \\
17: 48: 15\end{array}$ & $\begin{array}{l}\text { Marimarcio de Matos } \\
\text { Corsino Petrúcio }\end{array}$ & Acelto \\
\hline $\begin{array}{l}\text { Profeto delalhadol } \\
\text { Brochura } \\
\text { investagdor }\end{array}$ & Projeso_de_Pesquisa.por & $\begin{array}{c}2506 / 2015 \\
18: 28: 03\end{array}$ & $\begin{array}{l}\text { Tarnmarcio de Matos } \\
\text { Corsino Petrúcio }\end{array}$ & Acerto \\
\hline Outros & $\begin{array}{l}\text { Termo_Aquiescencla_Conselho_Muricip } \\
\text { al_de_Saude pdi }\end{array}$ & $\begin{array}{c}25 / 08 / 2015 \\
18: 31: 31\end{array}$ & $\begin{array}{l}\text { Marimarcio de Matos } \\
\text { Corsino Petrúcio }\end{array}$ & Acelto \\
\hline Forha de Fosto & Fona_de_Rosto2.pof & $\begin{array}{c}2508 / 2015 \\
18: 26: 51\end{array}$ & $\begin{array}{l}\text { Warmarcio de Matos } \\
\text { Corsino Petrúdo }\end{array}$ & Acerto \\
\hline $\begin{array}{l}\text { Informaçdes Basicas } \\
\text { do Proieto }\end{array}$ & $\begin{array}{l}\text { PB_INFORMACQDES_BASICAS_DO_P } \\
\text { ROÜETO 556232.pd }\end{array}$ & $\begin{array}{c}25 / 08 / 2015 \\
18: 38: 15 \\
\end{array}$ & & Acelto \\
\hline
\end{tabular}

situaça do Parecer:

Aprovado

Neceselta Apreclaçato da CONEP:

N50

BAURU, 18 de Setembro de 2015

\section{Assinado por:}

Izabel Regina Flacher Rublra Bullen

(Coordensdor)

\footnotetext{
Enderege: DOUTOR OCTAVIO PRHEIRO BeISOL 75 CUADFA 9

Bairro: VLA NOVA CIOADE LNEVERSTARIA CEP: 17.012-601

UF: SP Murlciploc BALRU

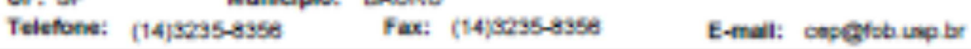

